\title{
Modulation of antibacterial resistance by subcellular preparations from "Listeria monocytogenes"
}

Citation for published version (APA):

Antonissen, A. C. J. M. (1986). Modulation of antibacterial resistance by subcellular preparations from "Listeria monocytogenes". [Doctoral Thesis, Maastricht University]. Rijksuniversiteit Limburg. https://doi.org/10.26481/dis.19861128aa

Document status and date:

Published: 01/01/1986

DOI:

10.26481/dis.19861128aa

Document Version:

Publisher's PDF, also known as Version of record

\section{Please check the document version of this publication:}

- A submitted manuscript is the version of the article upon submission and before peer-review. There can be important differences between the submitted version and the official published version of record. People interested in the research are advised to contact the author for the final version of the publication, or visit the DOI to the publisher's website.

- The final author version and the galley proof are versions of the publication after peer review.

- The final published version features the final layout of the paper including the volume, issue and page numbers.

Link to publication

\footnotetext{
General rights rights.

- You may freely distribute the URL identifying the publication in the public portal. please follow below link for the End User Agreement:

www.umlib.nl/taverne-license

Take down policy

If you believe that this document breaches copyright please contact us at:

repository@maastrichtuniversity.nl

providing details and we will investigate your claim.
}

Copyright and moral rights for the publications made accessible in the public portal are retained by the authors and/or other copyright owners and it is a condition of accessing publications that users recognise and abide by the legal requirements associated with these

- Users may download and print one copy of any publication from the public portal for the purpose of private study or research.

- You may not further distribute the material or use it for any profit-making activity or commercial gain

If the publication is distributed under the terms of Article $25 \mathrm{fa}$ of the Dutch Copyright Act, indicated by the "Taverne" license above, 
MODULATION OF ANTIBACTERIAL RESISTANCE BY SUBCELLULAR PREPARATIONS FROM LISTERIA MONOCYTOGENES 
MODULATION OF ANTIBACTERIAL RESISTANCE BY SUBCELLULAR PREPARATIONS FROM LISTERIA MONOCYTOGENES

(MODULATIE VAN DE WEERSTAND TEGEN BACTERIELE INFECTIES DOOR SUBCELLULATRE PREPARATEN GEISOLEERD UIT LISTERIA MONOCYTOGENES)

\section{PROEFSCHRIFT}

ter verkrijging van de graad van doctor in de Geneeskunde aan de Rijksuniversiteit Limburg te Mastricht, op gezag van de Rector Magniflcus, Prof.Dr. F.I.M. Bonke volgena het beglut wa

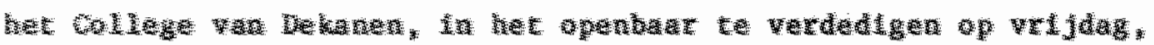

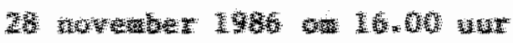

acter

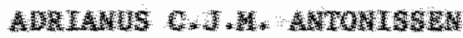

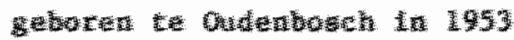




$\begin{array}{ll}\text { PROMUTOL: } & \text { Prof.Dr. C.P.A. van Boven } \\ \text { REPERENTEN: } & \text { Prof.Dr. P.J.C. van Breda Vriesman } \\ & \text { Prof.Dr. J.M.N. Hillers }\end{array}$

Het in dit proefschrift beschreven onderzoek werd grotendeels verricht onder begeleldLg van Dr. JW, van den Bosch, thans werkzam bij Intervet International B.V. te Boxmeer. 


\section{ACKNOWLEDGEMEWT}

The investigations reported in this thesis were supported in part by the Foundation for Medical Research Fungo (grant 900-514-38). 
Thls thesl is partially based on the following publications:

A.C.J.H. Anconissen, P.J.H.R. Lemmens, R. GonggrIJp, J.F. van den Bosch and C.P.A. van Boven. (1985). RNase-sensttive and RMaseinsensitive protect Ive components 1 solated from Listeria monocytogenes. Antonle van Leeiuwenhoek 51, 227-240. (Chapter 3i)

A.C.J.M. Antonisgen, P.J.M.R. Lemmens, J.F. van den Bosch and C.P*A. van Boven. (1986). Dissoclation between enhanced resistance and delayed hypersenstivity induced with subcellular preparations from Listerla monocytogenes and the adjuvant dinethyldioctadecylammonium bromide. Antonle van Leeuwenhoek 52, 75-84. (Chapter 4)

A.C.J.M. Antonissen, P.J.M.R. Lemmens, J.F. van den Bosch and C.P.A. van Boven. (1986). Purification of a delayed hypersensitivity-inducting proteln from Listeria monocytogenes. FEMS Mcrobiol. Letters 34, 91-95. (Chapter 5)

A.C.J.M. Antonissen, P.J.M.R. Lemmens, J.F. van den Bosch and C.P.A. van Boven. (1987). Transfer of enhanced resistance against Listeria monocytogenes Induced th ribosomal RNA and the adjuvant dime thyldioctadec ylanmoni um bromide. Immunology Letters 14 (1) (1n press). (Chapter 6)

J.F. van den Bosch, I.X.R. Kanls, A.C.J.M. Antonlesen, W.A. Burman and C.P.A. van Boven. (1986). T-celi-1ndependent macrophage activation in mice induced with rRAA from Listerla monocytogenes and dimethyldioctadecylammonium bromlde. Infect. Irmuin. $53,611-615$. (Chapter 8) 
Aan mitn oulerw 


\section{Listeria monocytogenes}

Chapter 4

Dissociation between enhanced rests-

tance and delayed hypersensitivity

induced with subcellular preparations

from Listerla monocytogenes and the adjuvant dimethyldioctadecylammonfum bronlde

Chapter 5

Purification of a delayed hypersensitivity-inducing protein from

ListerLa monocytogenes

Chapter 6

Transfer of enhanced resistance

against Listeria monocytogenes

induced with ribosomal RNA and the adjuvant d tme thyld loc tadec ylamon tum brom lide

Protection against Listeria monocyto-

genes Induced wh natural and symthetic RMA combined with the adjuvant dimethyldioctadecylammonium bromide: Correlation with enhanced phagocyte Inflammatory responses: 
Chapter 8

Protection aganst 1 ster los 1 s induced

wh th rbosomal BNA from Listeria

monocytogenes comblned with the adjuvant dimethyldioctadecylammonium

bromide (DDA) is due to a $\mathrm{T}$-cell

Independent mechantsa

Chapter 9 sumary and General Discussion

Samenvatting

Dankwoord

165

Curriculum vitae 


\section{CHAPTER I}

INTRODUCTION

Listeria monocytogenes is a Gram-postive bacterium which behaves, when it has entered the body, as a facultatlve Intracellular paraste. Its natural host cell ls the macrophage, in which the organism is able to survive and even to multely) (WHO Sclentific Group, 1973). However, a few days after Infecton macrophages acquire the capacity to kill Listerla, a phenomenon which is known as "macrophage-activation" (Mackaness, 1962, 1969). The activation of macrophages 1 s due to the action of Listerlaspecific $\mathrm{T}$ (thymus-derived)-cells, which recognize macrophageassociated Listeriarantigens. The Interaction between Listerlaspecifle t-cells and macrophage-associated LIsterla-ant 1 gens Induces $\mathrm{T}$-cell-proliferation as well as the secretion of soluble mediators (1ymyphokines) by $\mathrm{T}$-cel1s which prowote the accumulation and immobllization of macrophages at sites of Listerta-infection and activate these cells to kill Llsterla (Hahn and Kaufwann, 1981).

Opsonizing antibodies are only of minor importance (1f at all relevant) for the elimination of Listeria monocytogenes: Immundwation of mice with sublethal dose of viable Llsterta Induces a high level of protection agalnst lethal Infection, but only a mintmal production of opsontalng antibodtes. Conversely, dwunization wh klled bacterta lnduces tigh thtes of opsonling antibodies, but does not induce protection (Mackaness, 1962).

The ineffectiveness of k1lled-Listerla vacelnes has greatly hampered Ldentification of the lmmunogenfo componentio of this bacterium. However, in 1979. Van der Meer et al. reported that ice could be protected against lethal LAsterta-1nfection by Immunzation with k11led bacterla in combination withe adjuvant dimethyldictadecylammonlum bromide (DDA): Subsequently it was shown that protection could a so be Induced wth gubcellular 
preparatlons froin Llsterla monocytogenes comblned with DDA (H1lers et aln, 1979). In the latter atudy bacteria were mechanlcally distupted and separated into a cel1-wall fraction and a cell-contents traction by centrifugation. The cell-contents fraction was found to be more effective than the cell-wall fraction and therefore selected for further puriflcation. The immonogentc components present $1 \mathrm{n}$ the cell-contents fraction could be extracted with phenol. The phenol-extract, which contalned $60 \%$ nuclelc ac1ds, protected mice agalnst 11sterlosis in a dose as Low as 1 Hi. Its protective propertles were destroyed by Ralasetreatment, Indicating that RNA was the major protect lve component of thls preparation. The latter observation created a problem of an Interpret lve nature, as fumunlty to mlcro-organisms in generally assumed to be based on recogrition of cell-surface components or exotoxins.

Us Ing a modification of the fractionation procedure of W1lers et al. (1979), GonggrIJp et al, (1980) showed that RNase-sensitive as well as RNase-1nsensitive vaccines could be prepared from the Gram-negat Ive bacterlum Pseudomonas aeruginosa.

In the procedure of Gonggrijp et al bacteria were mechanlcally disrupted using a cold Hughes pressure cell. After treatment of the broken-cell suspension with DNase to reduce viscosity, unbroken cells and large cell-envelope fragments were removed by centrlfugation and fitration. Subsequently a crude rtbosomal preparation was prepared by ultracentrifugation. The crude ribosomal preparation wa separated lnto cell-envelope fragments (fraction t) and purffled rlbosomes (fraction II) by ge1-filtraton througlh a sepharose-CL-6B column in the presence of $1 \mathrm{M}$ $\mathrm{NH}_{4} \mathrm{Cl}$.

Fraction I laduced serotype-speclifle protection againet $\mathbb{P}$. aeruginosa Infection without the use of adjuvants. The protective properties of fraction I were not affected by RNase-treatment or tratment whth proteolytle enzymes. Fraction II lndueed sone protection without aduvants, but was considerably more effective when tested In comblnation with DDA. The protective propertes of fraction II (tested In combination with $D D A$ ) were destroyed by 
RWase-treatment, but not by treatment with proteolytic enzymes. Subsequently it was shown that protection could also be lnduced Wth purified ribosomal RNA extracted from fraction II, combined with DDA (Gonggrijp et al., 1981 a).

Whereas fraction I Induced serotype-speciftc protection - which was most likely due to the Induction of Itpopolysacchartde (LPS)specific antibodies (Gonggrijp et al, 1981 b) - protection ind - $^{-}$ ced with RNA plus DDA was serotypenonisecific as well as spectes-nonspecific (Gonggrijp et a1, 1981: a, 1983). Thus, two completely different protective components could be isolated from a single micro-organisu: fraction $I$, which induced serotype-specific immunty, and ribosomal RNA, which induced a general increase of antlbacterlal reststance when comblned with the adjuvant DDA.

\section{Purpose of this: study}

The purpose of investigations presented in this thests is to establfsh whether cell-envelope fragments (fraction I), purlfled ribosomes (fraction II), and purtfled rRNA lsolated from L. monocytogenes using the fractionation procedure of Gonggrldp et a1. (1980) induce protectlon agalnst LIsterta-1nfectlon, and to elucldate the mechanism of protection Induced by these preparations.

Following chapter $2 \mathrm{Ln}$ which a revlew of the literature on Listerla monocytogenes 18 presented, the chemlcal composition and the protective properties of fraction I and fraction II from L. monocytogenes serotype $4 \mathrm{~b}$ are described 1 n chapter 3 . Both preparatlons protected mice gainst homologous challenge, provlded that they were combined with the adjuvant DDA. R1bosomal RNA was 1dentHifl as the najor protective component of fraction II, because the protective propertles of this preparation were destroyed by Rase-treatment, but not by treatment with protelnase $k$. Furthermore, protection could also be lnduced wth purifled RNA extracted from fraction II.

The protectlve properties of fraction 1 were not affected by 
Rase-treatment, or treatment wh protielnase $K$.

otherwise, the protective properties of fraction I were highly sinlar to those of fraction II andor purified RAA. For Ingtance, fraction I plus DDA as 1 as RNA plus DDA also protected mice agalns L, monocytogenes serotype 3 , streptococcus pneumoniae, and P. aeruglnosa; Therefore $1 t$ was decided to Investigate whether fraction $\mathrm{I}$ and RNA might differ with respect to the ability to Induce or ellcte delayed hypersensitiwity (DH) response, which 19 as a umed to be reflectlon of the capacity of experimental antmals to mount a T-cel1-medtated mob11ization of macrophages to sttes of Listerla-ant 1 gen depos 1 tion.

As : hown In chapter 4, fraction I plus DDA Induced DH agalnst killed Literia, but RNA plus DDA did not. Furthermore, DH induced by Immunization of mice with viable listeria could be ellcited with fraction $I$, but not with RMA.

The DH-inducing components present in fraction $I$ were found to be of a protelnaceous nature, as protelnase $K$-treatment destroyed the abiltty of fraction $I$ to induce DH agalnst killed Listeria. As relatively $11 \mathrm{ttle}$ is known wh respect to the immunogenic components of Llsteria, Including $\mathrm{DH}$-inducing components, it was felt of interest to further characterize the DH-inducing components present in fraction $\mathbb{I}$.

Experdments th proteln-fractions lsolated from fraction I described in chapter 5 suggested that several proteins contributed to the Induction of DH wth fraction I. However, DH could a lso be lnduced th a purtified 20,400 MW proteln.

Further experiments were dedicated to elucidation of the mechanism of protection agains 11 sterlosis induced wth RMA plas DDA.

In chapter 6, it 1 s hown that mice treated with RNA plus DDA have an increased capacity to mobillze polymorphonuclear leukocytes (PMNs) and macrophages to the inflamed perttoneal cavity as compared to mice treated wth DDA alone. Results from transfer 
experiments wh resident and inflammatory peritoneal cells suggested that liflammatory PMNs as wel1 as Inflammatory macrophages from mice treated with RNA plus DDA were activated as compared to the analogous cell-populations from mice treated with DDA alone. Experfments wh polyanionic analogues of rRMA are described in chapter 7. From the substances tested, only the synthetic doublestranded RNA poly A:U combined with DDA approached the protective capacities of Listerla-rkNA plus DDA. Protection agalnst 11sterlosis Induced with poly A:U was assoclated with entanced Inflammatory responsiveness, in particular of PMNs.

Some results of the experiments described 1n the previous chapters suggested that protection agalnst Ilsteriosis induced with RMA plus DDA is not a pure local phenomenon but $1 \mathrm{~s}$ at least partially due to systemic effects. For instance, protection against Intraperitoneal infection could also be induced by subcutaneous instead of intraperitoneal immunization (chapter 3 ). Furthermore, inflammatory PMNs and inflamatory macrophages appeared to be more important than resident peritoneal macrophages for the expresston of protection Induced ith RNA plus DDA (chapter 6). For a more detalled analysts of the systemic ef fects of RNA plus DDA another experimental model was used than the ones previously employed, 1.e., mice were vaccinated subcutaneously (s.c.) and protection as measured as the capacity of wice to elimlnate Llsteria from spleen and 11 ver after intravenous (1.v.) challenge with a sublethal dose of live Listerla. Thts method was wsed because 1 a llows more accurate compartson of varlous vaccination protocols. Experiments in which the o.c./.1.v. model $1 s$ employed are described in chapter 8 .

Immunization of mice wth RNA plus DDA Induced an accelerated elimination of Listerla from spleen and liver, but was found to be considerably less effectlve than immunization wth viable Listerla. However, this situation was completely reversed when mice were treated wh the T-ce11-suppresslve drug cyclosporin A before and during the immunization period. Cyclosporin A completely inhiblted the induction of protection with viable Literia, but 
did not affect the Lmiduction of protectlon with RWA Plus DDA. Therefore protection induced wth RWA plus DDA was apparantly due to T-cel1-1ndependent mechanlsw, as already sugested by the abl11ty of poly A,U to mimle the protective properties of RMA (chapter 7), and the lnabllty of RM to lnduce DH agalnst Lsterla (chapter 4 ).

In chapter 9 , $1 \mathrm{n}$ which a sumary and general discussion are presented, two major conclusions are drawn:

i. Protection against Listerta monocytogenes induced 1 th RNA plus DDA lis due to a T-cell-independent mechanism.

11. Whereas the elimination of intracellular parasites such as LIsterla monocytogenes 18 generally assumed to be the privilege of actlvated macrophages, both activated macrophages and actlvated PMNs contribute to the expression of protection against listeriosis induced with RWA plus DDA.

RGEERENCES

Gonggr1Jp, R, MuLlers, N.J.H.A., Lemmens, P.J.M.R., and Van Boven, C.P.A. 1980. Rtbonuclease-sensitive ribosomal vaccine of Pseudomonas aerug Inosa. Infect. Immun. 27, 204-210.

Gonggrijp, R, Mullers, W.J.H.A., and Van Boven, C.P.A. 1981 a. Serotype-nonspecific protection Induced by ribonuclefc acid Isolated from the rlbosomal vaccine of Pseudomonas aerug dinosa; Infect. Immin, $33,178-185$.

GonggrAj, R, Volleberg, M.P.H., Lemmens, P.J.M.R., and Van Boven, C.P.A. $198 \mathrm{l}$ b. Evidence for the presence of 11popolysaccharide in a ribonuclease-sensitive ribosomal vaccine of Pseudomonas aeruglnosa. Infect. Immun $31,896-905$. Conggr.1D, R., Mullers, H.J.H.A., and Van Boven, C.P.A. (1983). Protective actvities of r rbosomal ribonucleic acid and 11 po polysacchartde of Pseudomonas aeruglnosas a comparative study: Antonle van Leewenhoek 49, 173-182. 
Hahn, H., and Kaufrnann, S.H.E., 1981. The role of cell-medlated immunty in bacterial infections. Rev. Infect. D18.3,12211250.

Mackaness, G.B., 1962. Cellular resistance to Infection. J. Exp. Med. $116,381-406$.

Mackaness, G.B., 1969. The influence of Immonologlcally comitted 1ymphoid cells om macrophage activity in vivo. J. Exp. Med. $129,973-992$.

Van der Meer, G., Hoftuls, F.M.A., and W11lers, J.M.N. 1979. Delayed-type hypersensitivity and acquired cellular resistance in mice tmmunized with killed Listerla monocytogenes and adjuvants. Immunology, 37,77-82.

WHO Sclentific Group. 1973. Cell mediated Immuntey and resistance. WHO Techn. Rep. Ser. 519,6-64:

W11ers, J.M.N., Bloksma, N., Van der Meer, C., Snlppe, H., Van Dijk, H., De Reuver, M.J., and Hofhuls, F.M.A. 1979. Regulation of the lmmune response by acrophages. Antonie van Leeuwenthoek $45,4 \mathrm{l}-48$. 


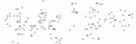

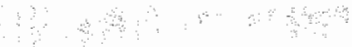

$\because \because$ $\cdots+\cdots, \quad:$ 
Listerla monocytogenes is a Gram-posttive bacterlum which behaves, when it has entered the body, as a facultative intracellular parasite. Its natural host cell is the macrophage in which the organtsm 1 s able to survive and even to multiply (WHO Scientific Group, 1973). The bacterium has been Isolated from sewage, water, mud, fodder, silage, earth and a varlety of animals including mammals, birds, flsh, crustaceans and limsects (Kampelmacher and Van Noorle Jansen, 1975; Wels, 1975; Gregorio and Eveland, 1975; Hys10p, 1975; Kampelmacher and Van Noorle Jansen, 1979). In addition, Listeria has been detected In the stools of upto $77 \%$ of healthy workers and $44 \%$ of healthy pregnant women (Kampelnacher and Van Noorle Jansen, 1972; Kampelwacher, Huysinga and Van Noorle Jansen, 1972).

Desplte the ublquitous presence of the bactertum, 11stertosts Is a relatively rare disease, which primar11y affects the fetus and the neonate (Seeliger and Finger, 1976; Kampelmacher and Van Noorle Jansen, 1979, Reller, 1979). In 55 to $74 \%$ of cases, neonatal Iisterlosis has been found to be assoclated with maternal disease during pregnancy whleh generally presents itself with Influenza-1ike symptoms (Relier, 1979; editorlal, 1980). According to Reller (1979) predominant clinical features of neonatal isteclosis were respiratory problems, enlargement of spleen and 11ver and neurologleal disorders. Mentngttis was only found in a mority of cases. The overall mortality rate in 75 cases reviewed by Reller (1979), was 22.6\%.

In a recent review (Nieman and Lorber, 1980 ) mentinglt1s was found to be the most commonly reported form of adult 11steriosis, accounting for $55 \%$ of all cases, whereas non-mentigitlc CNS lnfection accounted for an additional 6.5\%. Primary bacteremia was reported in $24.5 \%$ of cases and endocardttis $127.5 \%$. The remating $6.5 \%$ included cases of locallsed infection. Meningltis prinarlly affected males ( $70 \%$ of cases) and $62 \%$ of patients ith wentrigles 
were $>50$ years of age. In contrast, primary bacteremia was approxlmately equally divided over both sexes( $53 \%$ males) and $59 \%$ of patients were < 50 years of age.

Underlyling disease present in approximately $70 \%$ of cases of adul 11 ter1osis. In $46 \%$ of all cases patlents had recelved 1mmunouppress 1ve therapy, $48 \%$ of whom were renal tramsplant patlents. Cancer patlents accounted for $22 \%$ of all cases, and $75 \%$ of patlents wth underlying malignancles had recelved immunosuppresstive therapy. The overa11 mortallty was $25 \%$, but cons1derable differences were noted between different groups of pattents. In patients wth 1 isterial meningitis and underlying mallgnancles, it was $60 \%$ desplte antiblotic therapy, whereas in otherwe healthy ind 1 lduals it was only $13 \%$. In lmmosuppressed patienta without malignaneles, mortality from listerial meningitis was $28 \%$. In patients with primary bacteremia, the overal1 morta11ty was $11 \%$. In this group mortallty was restricted to patients with underlying mallgnancies, $33 \%$ : of whom died.

the propensity of Liaterla monocytogenes to infect the fetus and the neonate and adults with underlyling disease was corroborated by a recent outbreak of 11steriosis which was transmitted by pasteurized milk (Fleming et a1., 1985).

Ampledilin (in comblnation with gentamicln) has been suggested as the drug of cholice for the treatment of 1lsterlosis (Reller, 1979, Traub, 1981). Also other antiblotles have been shown to be effective agalnat Llsterla in vitro (Wigglns, Albritton and Feeley, 1978), but in vitro activlty does not always correlate with in vivo therapeutic effect. In a murine model of experimental ITserlosts, amplclilin wa found to be effective both in vitro and In v1vo, whereas the cephalosporins cefasedone and cephalotin were ony actlve tn vitro (Kawaler and Hof, 1984). However, also with ampicillin discrepancles between in vitro and in vivo activity have been observed. In contrast to normal mice, athymic (nude) mlce with Impalred I cell-medlated immulty could not be cured from listeriosis with amplicillin (Bakker-Woudenberg et al.. 1981, Hor, Emmerling and Seeliger, 1981): Also 1mpalrment of macrophage functions by treatment of mice with dextran sulfate 
reduced the efficacy of ampicillin treatwent (fiof et a I, 1981). Encapsulation of ampicllin within liposomes co Increase Imtracellular dellvery a the antiblotic enhanced its efficacy in normal mice, but dit not cure athyme mee from listeriosis (Bakker-Woudenberg et a1., 1985). These observattons stress the importance of the host's immune system ln the eradication of Infections due to Listerla monocytogenes.

It has been suggested that part of the mortallty associated with listeriosis might be due to a delay ln dlagnosis af the disease (editorlal, 1980; Howard et al., 1980). Indeed, both blood and cerebrosplnal fluid (CSF) can be terile for several days after the onset of severe clinical symptoms (Howard et a1, 1980). In addition, Listerla can be mistaken for a diphteroid contaminant or a streptococcal species (N1eman and Lorber, 1980). Fur thermore, the Infection may proceed withow a rise in antibody titres (Kampelmacher and Van Noorle Jansen, 1979; Mackeness, 1962), whereas postive serological findings may be due to cross reacthons 1 th other organisms (Seeliger and Hbine, 1979). Therefore, serological tests are considered to be useful only in combination wh th cultural and blochemical reactions: (Seeliger and Höhne, 1979). The predominant serotypes isolated from pathologleal sources are $1 / 2 \mathrm{a}$ and $4 \mathrm{~b}$ (Seeliger and Höhne, 1979).

\section{Blochemlcal pathology and virulence factors}

The pathogenesis of IIsterlosts and the mechandsms of protection against the infection have been studies extensively in experimental animals:

In lethally Infected mice a progreaslue decrease In total body weight and in the Intake of food and water has been observed. Absolute and relative liver welght, however, 16 increased. Bio chenical alterations in the liver include decrease in overall atrogen and proteln, increased $11 \mathrm{pld}$ content and lncreased xanthine dehydrogenase activity . Blood urea levels remain constant for the first 24 hours of Infection but then increase continuousiy to the acute tate of Infection (W11der and Sword, 1967a). BLood and liver glucose and liver glycogen show a progressive decrease 
after infection but pyruwte and lactate levels are increased (M11der and sword, $1967 \mathrm{~b}$; McCallum and sword, 1970). The hepactc ATP/ADP ratio is decreased with a concommitant increase in the MAD /WaDH rat Lo (McCallum and Sword, 1972a), studies on mouse

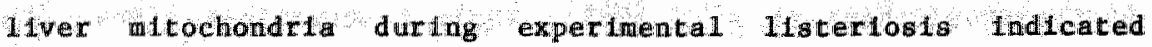
deramgement of the flrst alte in oxidative phosphorylation (McCallum and sword, 1972b). The pattern of 1ysosomal enzymes appearlag in plasma durfing 1 isterlosts suggested the accurrence of thsue damage in the liver (Sword and W1der, 1967).

VIrulent strains of Lilsterla monocytogenes generate an oxygenlab1le, cholesterol-Inhtbltable hemolysin capable of kililng phagocytle cells and also displaylng cardfotoxle and lethal propertles (Kampelmacher and Van Noorle Jansen, 1972, KIngdon and Sword, 1970, a, b, c) Hemolysin production might lncrease the amount of lron awallable to the micro-organism, which is restricted by several irom-binding protelns (Welnberg, 1971). The in vitro production of hemolysin wa found to be Inversely related to the medlum Iron concentration (Cowart and Foster, 1981). Iron stimilated both the in vivo and in vitro growth of Listerla monocytogenes and experimental 1 ron overload caused a reduction of LD50 values with more than 3 log unlts. Conversely, an approximately 30-fold Increase of LD 50 values was observed in mice treated with the Iron chelator Desferal (Sword, 1966).

The monocytosis seen is Listerfa monocytogenes infections could be reproduced by injection of a lipid-extract (deslgnated "monocytosLs-producling agent") (MPA) frot the bactertum. MPA in contribute to the pathogenesis of 1 isteriosis, as $1 \mathrm{t}$ was found to cause a derangement of sterold- and carbohydrate metabolism (Holder and Sword, 1969). A purtfled cel1-wall fraction 1solated trom Llsterla Induced a decreased resistance to Infectlon when injected flye days before untll one day after challenge with 1 lve organisms (Baker and Campbel1, 1978). Furthermore, Listerlapeptldoglycan was reported to be reslstant to 1 ysozyme (Kamisango et al, 1982) which night contribute to the peralstence of the Hifection. 
Host response to experimental 11 sterlosis

Response to primary Lnfection: According to MLtsuyamatet (1978) the host response to experimental 11sterias 1 s can be divided into three phases:

- First phase

When normal tilce are injected intravenowsly wh a relatively sinall Inoculum of Listeria monocytogenes, most of the bacterta are trapped in the liver within 10 min after administration. $B$ 6 h after infection, the number of viable bacteria in the Inver is decreased approximately tenfold. Thls phase of host resistance is attributed to fixed macrophages. It is inhibited by calrageenan treatment, but not by X-Irradiation. The Inttial reduction of the number of bacteria is not seen when the Inocu Ium is given intramuscularly, probably because of the small number of flxed macrophages in the muscle.

- Second phase

From 6 to 72 h after infection the number of bacteria shows progressive Inerease, but appears to be 1 imlted due to accumulation of free phagocytes at the stte of Infection. During this perlod bactertal growth ls markedly enhanced by X-irradiation or carrageenan treatment. Imvolvement of free phagocytes wa: inferred from the observation that the effect of Irradiation could not be inhibited by shielding of the liver durfing irradlation: These free phagocytes could be polynorphonicleat granulocyces (PMNs) because thls was the predomlnant cell type In LAsteria-1ndaced Lestons in the liver for the firgt 48 h

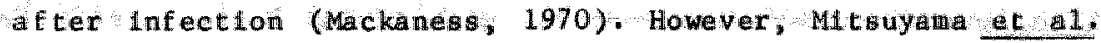
(1978) suggested that the second phase of hos restscance wat most likely due to circulating immature macrophages (monocytes), because carrageenan primarlly affects macrophages and because blood monocytes or the ir precursors are radio-sensltive unlike flxed macrophages. These conflicting resulta could be reconclled, If restriction of the growth of Listerta durtug the second phase of host resistance as defined by Mitsuyama et al. (1978) as assumed to be due to some form of co-operation 
between PHAs and macrophages. Such a co-operation sould be expected to be Inhiblted by treatments which affect elther PMNs ( $x$-Irradlation) or macrophages (carrageenan treatment). In this respect $1 \mathrm{t}$ should be noted that PMN-medlated macrophage act 1vation has been observed (Chapes and Hakk11, 1983).

- Third phase

Prom day 4 after Infection the number of bacterla $1 n$ spleen and llver begtns to decrease to become undetectable by day 9 . This last phase of host resistance ls attributed to 1 mmunologically activated macrophages. It $1 \mathrm{~s}$ inhibited by $\mathrm{X}-\mathrm{irradiation}$ and carrageenan treatment.

Response to secondary Infection: In mice Immunfzed with viable Llaterla 14 days prevlously, the number of bacteria tn the 11ver shows a contlnuous decrease after rechallenge. The course of infection during the first six hours, however, is almost ldentical to that in non-1mmunized controls. Therefore, it was suggested that In immunized animals the first phase of host reststance is followed Immedlately by the third phase (Mitsuyama et a1., 1978). Slmilar results were reported by Mackaness (1962) who studied the outgrowth of Llsterla $1 \mathrm{n}$ spleens of mice relnfected at varying Intervals after a primary Infectlon. Enhanced elfination of Llster1a was observed even 13 weeks after Immunization. Enhanced elimination without preceding outgrowth, however, was only seen when mlce were relnfected 1 or 2 weeks after primary infection.

Several other syatems have been used to analyze the course of secondary Infection: In the procedure used by Myata et a1. (1982) 1 tee were Immunlzed Intravenously wth 1 1ving bacteria and cha1lenged via the Intraperitoneal route. Elinination of the challenge Inoculum from the peritoneal cavity was taken as a measure of host response and the Involvement of pert toneal macrophages In this process was studied. Enhanced ellmination of the lnoculum was observed as early as 5 days after Immunlzation but was more pronounced after 15 days. Macrophages obtalned by lavage of the perttoneal cavity 5 days after Immunization did not show enhanced phagocytosis or killing of Listerla in vitro. However, a marked 
increase in the number of pertitoneal wacrophages was observed $24 \mathrm{k}$ after challenge. In contrast, macrophages obtalned 15 days after Immunization were found to be activated, 1 .e thetr capactiy to kIII Listeria in vitro was Increased when compared with normal macrophages or macrophages obtalned 5 days after limumization. The increase in the number of peritonem 1 macrophages abserved 10 mice challenged 5 days after immunization was absent when the challenge was given after 15 days.

Thus, the generation of acquired cellular resistance was divided in two phases: a first phase characterlzed by the accumulation of normal macrophages at the site of re-infection, and a second phase, characterized by the appearance of so-called acturated macrophages (Miyata et a1., 1982).

Absence of increased bacterlcidal properties has also been observed In murlne peritoneal macrophages 7 days after intraperitoneal immunization with live bacteria. However, perltoneal maccophages obtained from 1 mmunized mice 18 h after intraperitoneal injectlon of heat-killed LIsterla were found to be act ivated (Harringtom-Fowler, Henson, and Wlder, 1981). Both the enhanced accumulation of normal macrophages as described by Myata et al. (1982) and the accumulation of activated macrophages as described by Harrington-Fowler et a 1 (1981) were apparently due to some form of recognition of Listerla-antigens, because nelther phenomenon occurred when mice were Injected with substances unrellated to Listerla monocytogenes.

\section{Mechanism of Imtanlty agadnst Listerla monocytogenes}

Elucidation of the mechantsm of Iminity agalnst Listerla was Intclated by Mackaness, who observed that reststance could be transferred to normal mice with spleen cells from antmals Immunized wh a sublethal dose of living bacterla (Mackaness, 1969). Protection could not be transferred with serum from mce lmunlaed with elther vlable or killed Listerta. Sierun fron mice lmmunized with klled Listeria contalned high thtres of agglutinating antibodies, but immuntation wth kl1led bacterla did not protect mice against 11steriosis (Mackaness, 1962). 
The transfer of protection wh spleten cells was found to be speell1c, as spleen cello from mice limunlzed with BCo did not protect reclplent mlee agalnst Llsterla- However, when mlee were Injected with BCG-1mmune spleen cells lin comblnation wh riable BCG, thelr reststance agalnst Llaterla was found to be enhanced. Futhermore, listertcidal macrophages could be lsolated from mice Ingected $48 \mathrm{~h}$ prewlously wh BCG-1mmune spleen cells in comblnation with $B C G$, but not from antmals which had recelved normal spleen cells in comblination with BCG or BCG-1mmune spleen cells alone. As Immune-spleen cells by themselves were not bacterlcldal, It was concluded flrstly, that the expression of lmmunty agalnst Intracellular bacterla 1.8 based upon a spectflc interaction between sensitised lymphold cells and the lmmunizlng organism, and secondly, that this speclfic interaction generates a nonspecifle s1gnal which activates macrophages to kll Intracellular bacterla (Mackaness, 1969 ).

The 1ymphold cells involved 1 in the transfer of protection agalnst LLsterla were found to be thymus-derived ( $\mathrm{T}$-) cellis, as Immune spleen cells treated with antiserum agalnst a thymocyt Ic surface antigen (ant $-\rightarrow$ serum) plus complement no longer protected rectplent mice agalnst 11ster1osls (North, 1973). Subsequently, Llsteria-speciflc $\mathrm{T}$-cells were shown to accumulate in sterile perttoneal exadates, Induced by the injection of caseln. On a per cell basis, exudate cells were approximately slx times more efflclent than spleen cells in protecting reclpient mice agalnst infection (North and Spitalny, 1974).

The interactlono between Llsterla monocytogenes, Listerlaspeciflc $\mathrm{T}$-cells and macrophages have been analysed $1 \mathrm{n}$ detall. The results of most of these studles have been revlewed by Hahn and Kau fmanin $(1981)$ and Unanue $(1981)$.

In vitro activation of Lleterle-spectic T-cells (measured as T-cell prollferation) by killed Listerla was found to requlre the presence in the Incubation mixure of macrophages expressing Iaantlgens (Welnberg and Unanue, 1981). Ta-ant1gens (1mmune response regton assoctated antigens) are products of the I locus of the major histocompatibility complex (MHC) of the mouse $(\mathrm{H}-2)$. H-2I Is 
Invalved in the genetic control of speciflc Imune responses to certalu polypeptide antlgens and also codes for cell surface structures that are expressed on cells of the lmmane system (Bce11s, macrophages and some T-cel1s) (Hahn and Kaufuann, 1981). Ingestion of kilied Listeria by macrophages was found to be essentil for the induction of $\mathrm{T}-\mathrm{ce} 11$ prollferation. Heterologous bacteria could not substitute for Llsteria (Weinberg and Unanue, 1981). Typically, the interaction between Listeria-spectflc Tcells and Listeria-pulsed macrophages could not be blocked by anti-Listerla antibodies. Furthermore, this interaction was genetically restricted, 1.e., both $\mathrm{T}$-cells and macrophages had to be derived from donors which were identical at the I-A subreglon of the If locus of $\mathrm{H}-2$ (Farr, Klely and Unanue, 1979).

These and other observations have led to the concepts of antigen-processing and antigen-presentation by macrophages, which means - In this context - that T-cel1s w111 not respond to ant 1 gens of Intracellular bacterla unless these antigens are modifled by macrophages and presented to T-cells In combination or close association with MHC-products (dual recognition modei). In an a1ternative mode1, $1 \mathrm{t}$ is proposed that MHC-products are modified by the antigen and that the $\mathrm{T}$-cell recognizes a new antigentc determinant (altered self-mode1) (Hahn and Kaufmann, 1981).

Culture of Listeria-1mme $\mathrm{T}$-cells wth Listeria-pulsed macrophages also resulted in the acquisition of tumortcldal activity by the macrophages. The generation of tumoricidal macrophages required homology at the I reglon between macrophages and T-eells, as well as the presence of macrophages bearling la tolecules. Macrophage actlvation was found to be medlated by a soluble factor which activated byngenelc as we 11 as allogenelc macrophages, and macrophages lacking detectable Ia molecules. Thus, only the 1nduction, but not the expression of tumarldicdal activity was genet - $^{-}$ cally restricted (Farr et a1., 1979). H-2 restrlcted binding of $\mathrm{T}$ cells to macrophages was essentlal for the generation of tumortc dal and mitogenelc act Lvtty (Zlegler and Unanue, 1979).

Zlakernagel et al. (1977) reported that the transfer of enhanced resistance against Listerla with Listerla-1mmune spleen cells 
w. H-2I restricted. In contrast, cheers and Sandrin (1983) concluded that the adoptive transfer of resistance was H2-K restricted, and suggested that the results of zlakernagel et al. (1977) might have been confounded by restriction at non-H-2 $10 \mathrm{cl}$ (Cheers and Mokenzle, 1983 ).

In transer experiments with Listexla-immune peritoneal exudate $T$ cells, only a low level of teststance could be tramsferred to $\mathrm{H}-2 \mathrm{~K}$ Incompattble reciplent nlce. I-A incompatibility did not lahiblt the transfer of protection, indicating that $\mathrm{H}-2 \mathrm{~K}$ restriction was more lmportant than restriction at H-2I-A (Hahn and Naher, 1984; Wher, SperLing and Hath, 1985). The crucial factor 1n H-2K retricted transfer of pratection appeared to be an accelerated formation of granulomas (ctrcular lesions composed of a compact and orderly arranged cellular inf11tration of predominanty mononuclear cells) upon infection of reciplent mice with Listeria, which was not observed when acceptor mice had recelved H-2I-A compat1bLe/H2-K incompatible T-cells (Hahn and Naher, 1984; Naher et a., 1985). Furthermore, viable bacterla had to be injected to promote granuloma formation (Naher et al., 1985), whereas k11led Listerla were sufficlent for the H-2I restricted generation of $T-$ cell mitogenic and macrophage tumoricidal activity in vitro (Farr et a1., $1979 \mathrm{a}, \mathrm{b})$.

Also in the rat discrepancies between in vitro and in vivo studles have been observed. In vitro proliferation of Llsterlaspectic T-cel1s upon stimulation wh LIsteria-antigen was found to be restricted by $\mathrm{RH} 1-\mathrm{B}$ (which 18 the and logue of murtine $H 2-I-A)$ whereas the transfer of protection was more effecture in the case of RT1-A (analogue of murlne $H-2 K$ ) homology than in the case of howology at RT1-B (Jung1 and Jung1, 1982, Jung i et a1, 1982).

Uling antisera agalinst $T-1$ ymphocyte cell surface antigens (Lytantigens, Ledbetter et a, 1980 ), Katimann, Stmon and thahn (1979) concluded that the systenlic transfer of protection and delayedcype hypersensth1Vity (DTH) against LLsterla was mediated by $T$ cel1s expresslng Lyt 1, Lyt 2 and Lyt 3 ant 1 gens (Lyt $1,2,3^{+}$Icelds).

Systemlc transfer of protection and DTH could also be achleved 
with Listeria-speclfic clomed T-cells, but required relativily high cell numbers. Cloned I-cells were obtalned by In vitro propagation of Listeria-immune peritoneal exudate $\mathrm{T}$-cells In the presence of syngeneic accessory cells (1rradlated spleen cells) and killed Listeria. In vitro poliferation as well as the transfer of protection with cloned T-cells was H-2I-A restricted Kaufman and Hahn, 1982). Cloned T-cells were less effective than uncloned cells to the systemic transfer of protection, which was probably due to the trapping of cloned $\mathrm{T}-\mathrm{cells}$ In the lungs of recliplent mice. On the other hand, cloned $\mathrm{T}$-cells were more effective than uncloned cells in the local transfer of protection, which was assessed by combined injection of $\mathrm{T}$-cells and live Llsterla into the footpads of reclpient uice (Kaufmann, 1983):

The T-cell clone studied by Kaufinann (1983) was derived from a T-ce11 Line of Lyt $1^{+}{ }^{-}$phenotype. Nher, Sperling and Hahn (1984) reported that maturation of Lyt $1,2,3$ cells 1 to cells of $\mathrm{Lyt} 1^{+} 2^{-}$ phenotype also occurs in vivo. Furthermore, also Lyt ${ }^{+} 2^{-}$cells generated $1 \mathrm{n}$ vivo had a ceduced capacity to transfer systemlc protection, but were quite effective in the local transfer of resistance towards Listerla. Local transfer of protection with cloned T-cells was genetleally restricted and opeclfic for $\mathrm{L}$. monocytogenes. On the other hand, both systemlc and local protecthon could be transferced to syngenele as well as allogenele mice with supernatants from cloned T-cells atimulated In vitco with killed Listeria in the presence of accessory cella $\mathrm{T}$-cell supernatants also protected mice against Salmonella typhinurtum (Kaufinan, 1983), conflrming the nonspeclflc nature of the effector phase of resistance agalnst Intracellular bacterta (Mackaness, 1969).

Subsequent1y, it was shown that LIsterla-tmme Lyt $\mathrm{T}$-celis produced $\gamma$-interferon (IFN- $\gamma$ ) ln vitro upon stmulation with k111ed Listeria in the presence of ant1gen presenting ceilg (proteose peptone-induced perttoneal exudate cells from momal syngenetc mice). Klled Listerta could be substituted by the ifcell nitogens concanavalin $A$ (ConA) or phytohemagglutintn (PHA). However, PHA-1nduced as 11 as k111ed L1sterta-1nduced IFN pro- 
duction sa several fold higher with LIsterla-imme T-cells than wth normal T-cel1s. Killed Listerla alone were not mitogenic and an unrelated antigen (sheep red blood cells) did not induced IFN production.

A1so Ltaterla-bpeclfle cloned $T$-cells produced IFN- $Y$ in vitro (Kaufmann et al, 1983). Recombinant IFN- $\gamma$ (rIFN-p) protected reclpitent nice againgt local as well as systemic Infection with Listerla monocytogenes. Purthermore, it protected mouse L-cells agalnst the cytopathle effect of vestcular stomatitis virus and it also activated macrophages to kill tumor cells in vitro. Whether In vitro incubation of macrophageg with rIFN- $\gamma$ also resulted In enhanced 1 sterlcldal activity was not reported (Kiderlen, Kaufmann, and Lohmann-Matthes, 1984). However, both human and mut Ine recombinant IFN- $\gamma(\mathrm{rIFN}-p)$ were shown to activate macrophage to k111 Toxoplasma gond11 dn vitro (Nathan et a1, 1983; Murray, Spltalny and Nathan, 1985), Indicating that IFN-p can enhance macrophage microbicidal activity.

Bestdes IFN- $p$, LLterta-1mmune Lyt1 T-cells also produced incerleukin 2 (IL2; formerly TCGF ( $\mathrm{T}$-ce11 growth factor)) and mlgration lnhibition factor (MIF) which is thought to promote the immobilisation of macrophages at sltes of infection (Kaufmann et A1., 1982; Sperlling, Kaufmann, and Hahn, 1984).

In vitro prollferation of Listerla-immune T-cells upon Incubatlon with macrophages and killed Listerla was mainly due to expanaton of the Lyt $1^{+} 23^{-}$subset. Prollferation was suppressed by act Ivated merophages from mice immuntzed with viable Listeria or treated th Corynebactertum parvum. Suppresston of prollferative responses was probably due to prostaglandin secretion by macrophages: Lyt $123^{+}$cells contributed to the prollferation of the Lyt $1^{+} 23^{-}$subset by counteracting macrophage-medlated suppression (kaufwann, Stwon, and Hahn, 1982).

Using a dfferent set of markers, Kaufmann et al. (1985) found that the systemic transfer of protection and DTH agalmst LLsterta depended on a co-operation between $T-c e 11 s$ carrylng the $L 3 T 4$ and the Lyt2 narker, respectively. L3T 4 and Lyt 2 are reciproc111y expressed by different subsets of $\mathrm{T}$-cel1s. Therefore $\mathrm{L} 3 \mathrm{~T}^{+}$cel1s 
could be obtalned by incubating unselected $\mathrm{T}-\mathrm{ce} 11 \mathrm{~s}$ wh ant $1-\mathrm{Lyt} 2$ ant lserum plus complement and vice versia. Protection and Dra could be transferred with a comblnation of both-subsets, but not with elther subset alone. Previously it was shown that systemic protection and DTH could not be transferred with $\mathrm{Lytl}^{+} 23^{-} \mathrm{cells}$, Ly $\mathrm{LI}^{-} 23^{+}$cells, or a combination of both subsets, which prompted the conclusion that $T$-cells carrying all three surface markers (Lyt 123 cells) were essential for the systemic transfer of protection and DTH (Kaufmann et a1., 1979). However, In the latter study anti-Lyt1 antiserum was used to obtaln the Lytl $23^{\text {t }}$ subset. Because Lyt is expressed on all $\mathrm{I}$-cells (albeit at differtng densities) (Ledbetter et a1, , 1980) treatment with ant 1-Lyt1 antiserum plus complement may have eliminated part of the Lyt $2^{+}$ population.

As $13 \mathrm{~T} 4$ and Lyt 2 antigens appear to be Involved in the interaction of $T$-cells with class 2 (murine $\mathrm{H}-2 \mathrm{I}$ ) and elass 1 (murline $\mathrm{H}-2 \mathrm{~K}$, D) encoded products, respectlvely (Swaln et al, 1984), Kaufmann et a 1. (1985) noted that thell findlings would Indtcate that both class 1 restricted Lyt $2^{*} \mathrm{~T}$-ce $11 \mathrm{~s}$ and class 2 restricted L $34^{t} \mathrm{~T}-\mathrm{cell}$ s contribute to the transfer of protection and $\mathrm{DTH}$.

At flrst sight, thls concept is incompatible with the obser vations of cheers and Sandrin (1983) who showed that H-2K homology between donor and acceptor mice is necessary and sufficlent for the adoptive transfer of protection. However, as noted by wather et a1. (1985), the poss1bi11ty that Lyt $2^{-}$(and thus $\mathrm{L} 3 \mathrm{~T}^{+}$) $\mathrm{T}$-ee11s might contribute to the transfer of protection $1 \mathrm{n}$ a maner which 16 not rescricted by MHC products, 1 .e. Whlch $1 \mathrm{~s}$ not based upon recognition of Listerta-antigens In combination with La-antigeng, has not been formally excluded. The H-2K restrictlon observed by Cheers and sandrin (1983) and Naher et a1. (1985) 1s rather surpristig, as class 1 restriction $1 \mathrm{~s}$ apleal feature of the cytotoxic response agalnst virus-1nfected cells (Ada, Leung and $\mathrm{k} t \mathrm{t}$, 1981) Whether Listeria-specif1c T-cells k11 Llsterla-1nfected ce11s $1 \mathrm{~s}$ under investigation (Kaufmann et a1., 1985). However, $1 \mathrm{t}$ is difficult to loggine how k1111ng of lnfected cells could contribute to the elimination of Listerla, unless ingested bacterla 
are also k111ed in the process.

In the studieg of Cheers and Sandrin (1983) and Nather et al. (1985) partlaliy HHC-Incompatible -cells were transferred to define the MHC locus Involved in the restriction of the adoptive transfer of protection. As consequence of allogenelc stimulaton, transferred $\mathrm{T}$-ce 11 s of Lyt 2 phenotype may have produced IL2, wheh 1a helper factor for cytotoxic responses (Farrar et a1, 1982). In the study of Kaufmann et al. (1985) coculture of a comblnation of $314^{+}$and $L y t 2^{+}$cells with allogenelo 1 rradlated spleen cells promoted the gemeration of T-cells whlch were cytotoxic for P815 tumor cells. $3 \mathrm{~T}^{+}$but not Lyt $2^{+}$cells could be substituted by IL2 containing supernatants from con A stlmulated s pleen cells, Indtcating that $\mathbb{L}_{3} 4^{+}$cells provided help for the generation of cytotoxic effector cells from the liyt $2^{+}$subset.

Thus, In vivo studies with congenelc mouse stralns and serologlcally alected $\mathrm{T}$-cells point to a helper function for $\mathrm{L}_{3} 4^{+}$ cellis and an effector function for $\mathrm{Lyt} 2^{+}$cells, whereas the reverve reliation emerges from experiments which rely in whole or in part upon in vitro stimulation of Listerla-specific T-cells with klled Listerla. Furthermore, $1 t$ should be noted that injection of a k1led Listeriarpreparation Into Listerla- Imumized mice appeared to be much more effective for the ellcltation of IFN- $v$ production than reinfection wth viable bacteria (Nakane and Minagawa, 1984). In addition, rather high amounts of rIFN- $p$ were required to protect wice galins aystenlc Infection with Listeria (Kiderlen et A1., 1984). These observations ralse the questlon whether IFN- $p$ wight not functlon as a helper factor which Increases the sens 1wylty of $\mathrm{T}$-cells for stmulation by IL2 (Farrar et al, 1982), rather than as a factor which actlvates nacrophages to k111 Llsterta.

Ceuprynsk1, Henson and Campbe11 (1984) found that mice lmmunlzed Wth viable Listerla responded with an Increased influx of PMNs and macrophages upon Intraperitoneal injection of k1lled L1sterla or proceose peptone Inflamatory $\mathrm{PMMs}$ and aacrophages k11 L Listeria in vitro more efflciently than resldent macrophases, but on a per cell basis, cells from control mice vere as 
effective as cells from Immulzed animals. Therefore, Czuprynski et al. (1984) suggested that an increased abllity to mobilize phagocytes to sites of Infection, rather that wacrophage activation, wight be of prime importance in reslstance to 11sterlosis. Also human PMN have been shown to k1L Llsterta In vitro (Mackowan et a1., 1983). Otherwise, the contribution of MMN to resistance agalnst 11 sterlosis has recelved little attention. Tatsukawa et a1 (1979) reported that murlne PMNS did not k111 Listeria in vitro, but in thelr assay also macrophage-mediated killing of Listerla was hardly if at all detectabile.

Increased inflammatory responsiveness as reported by cuuprynskl et al. (1984) could be transferred to normal rectplent mice with Llsterla-Immune I-cel1s (Czuprynsk1, Henson and Campbe11, 1985).

In sumary, collectlve data from studles dedlcated to the function of $\mathrm{T}$-cel1s in anti-Listerla immunty indicate that Listerla-immune $T$-cells migrate to inflamatory focl provoked by Llsterlarinfection where they promote the accumuliation of phagocytes and granuloma formation, and activate macrophages to k111 Listerla. Matters to be resolved are, among others, the contribution of PMNs to anti-Listerla immun 1 ty, the 1nteractions between PMNs and Listerla-speciflc $T$-cells, and the contribution of cytotoxic $\mathrm{T}$-cells to protection against Listerla.

Non-specific emhancenent of host reststance agalnst Listerla monocyt Logenes

Prom the 11terature revlewed In the previous gecton, it hä become clear that the induction and expresslon of $\mathrm{I}-\mathrm{cell}$ dependent protection agalnst Listerla Is based upon a speific recognition of Listerla-antlgens by $\mathbb{1}$-cells. Nevertheless, enhanced reststance agalnst Listeria has also been induced wth substances which are structurally unrelated (as far as can be Judged) to Ltbterta antigens. Therefore, enhanced reststance lnduced with wuch gubtances is termed "non-spectfle". The expression "non-spectfle reststance Ls also used to Indlcate that a substace Induces enhanced reststance agalnst several uncelated micro-organlams. Nom-speciflc reslstance agalnst Llgterla has been Induced with 
Yable and kllied heterologous bacterla (Blokma, De Reuver, and W11ers, 1983), 11popeptldes (B1oc'h et al, 1981; Parant et al., 1980), polyacrylamide beads (Fontan and Fauve, 1983), symthetfc and natural RNA (Fauve, 1971, Hedina, Vas and Robson, 1975), an acellular extract (AEP) from Pseudomonas aeruginosa (Fawchere, S1monet and (Eron, 1982), B-glucan from Plchla fermentans (Had b1, Bastlde amd Bastlde, 1981), zymosan (Bloksma et a1., 1983), tale (Fontan et a1., 1983), and tunor necrosts serum (TNS) (Parant, Parant, and Ched1d, 1980).

AEP-treatment of mice resulted $1 \mathrm{~m}$ an Increased accumulation of phagocyte at the ste of infection. In comparian with cells from control-treated animals, macrophages from $\mathrm{AEP}$-treated mice respondied with an enhanced Inttal rate and a higher peak production of chem1lumescence upon in vitro stlmulation wh Listerla, suggesting that AEP-treatment stimilated phagocytosis and oxygen-dependent bactertcldal systema. However, total chemlluminescence was essentlally ldenttcal for macrophages from AEP-treated and control-treated mice. Furthermore, enhanced clearance of an Intravenous lnoculium of Llaterla from the 11vers and spleens of AEPtreated mlce was not detectable unt 11 2-3 days after lnfection (Faucherre et a1., 1982). At approximately the same time a specif lc Immune regponse towerds Llsterla begins to develop (North, 1973). Therefore, $1 t$ was suggested that AEP probably only increased the efflctency of phagocytes as effectors of the spectflc immue resonse. ABP also protected mice agalnst Salmonealla typhimur1um, Serrat1a marcescens, Klebslella pneumontae and Pseudomonas geruglnosa (homologous as well as heterologous), but the mechanlsm of protection agalnst these organisms was not analysed in detall (Fauchère et al., 1982),

Several blologlcal effects of $\beta$-glucans wight be relevant for the Induct ton of enhanced reslstance galnst Llsterla with zymosan and glucan from Plchla fermentans (Bloksma et al., 1983; Hadlb1 et 21., 1981). $\beta$-GLueans were shown to enhance the generation of cytotoxic p-cells, which might be due to an effect of $\beta$-glucans on macrophages Glucan-activated wacrophages had a decreased capaclty to secrete prostaglendin 1 , thich suppresses the prolfferation 
and cytotoxlic effector function of cytotoxlc T-cells (Hamuro, R61linghof, and Wagner, 1978)/. Prostaglandin $\mathrm{EI}$ has been show to promote the Induction of suppressor $\mathrm{T}-\mathrm{ce} 11 \mathrm{~s}$ (Fulton and Levy, 1981). Conversely, Inhibitors of prostaglandin synthesls (aspirin and indomethacim) fmbibited the generation of T-suppressor cells (Nicklin and Shand, 1982). Therefore, glucan-treatment wight ald in the generation of a spectflc immune response towards Llsteria by Intbiting $\mathrm{T}$-suppressor cell functions. Studles with zymosanderived glucan Indicated that glucan-adminlstration resulted tn increased granulocyte and macrophage production (Burgaleta and Golde, 1977). Thus, also Increased numbers of avallable effector cells might contribute to enhancied reslstance against Listerla Induced with zymosan; or glucan from Plchla fermentans.

Enhanced resistance agalnst Listerla Induced with polyacrylamide beads or talc (Fontan and Fauve, 1983, Fontan et al, 1983) could be transferred to normal wice with proteln fractions 1 so- $^{-}$ lated fom granulomas which devellop upon subcutaneous Injection of these materials. From talc-Induced granulona a protein was pur fied (MN $55000+2000$; pH1 $5.0+0.1$ ) which enhanced the reststance of mice towards Listeria when given $1 \mathrm{n}$ a dose of 5 pg (Fontan et a1, 1983 ).

Medina et al. (1975) reported that Inherently resistant (C57BL/6J) but not inherently sensitive (A/J) milee could be protected against Listerla 1 th RNA. The Inherent reslstance of C57BL/6J mice was found to be linked with Hcreased macrophage and PMN Inflamatory responses (Stevenson, Kongmavn, and skamene, 1981, Gervals, Stevenson, and Skamene, 1984). The Inherent su $\theta^{-}$ ceptlbilty of $\mathrm{A} / \mathrm{J}$ mice appeared to be partially due to the $\mathrm{CS}$ deficiency of these mice, which prevents the generation of the chemotactic complement fragments C5a and C5a des arg (Gervals et a1. 1984; Czuprynskt et al., 1985). Transfer of C5-sufflctent plastia to $\mathrm{A} / \mathrm{J}$ mice enhanced PMN 1 nflamatory responses (Czuprynsk1 et a1. 1985), and transfer of C5-suffletent serum enhanced the resistance of $\mathrm{A} / \mathrm{J}$ mice towards Listerla Infection (Gervals et a1., (1984). Whether complement factors were 1 nvolved in the induction of enhanced resistance with RNA has not been establlahed. It 
should be noted that there are also C5-sufflctent stralns of mice (for linstance BALB/c) which are nonetheless senslttve to LIsterlaInfectlon (Cheers and Mckenzle, 1978). However, also differences In Lahurent reslstance towards LAsteria between C5-sufficlent mice Whe found to be asoclated with differentlal inflamatory responses upon Infection whth LIsterla (MandeI and Cheers, 1980 ).

Inflamatory agents were reported to promote the production and/or release of LL1 (Geryet a1, 1981), and ILI-1ike (Goto et a1. 1984) and IL2-11ke (J1n sheng et a1, 1982) factors. Inflammatory rat FNs were show to produce low M $(<10,000)$ factors which promoted the prollferation of macrophages and stimulated macrophage chemiluninescent responses (BIrd, Jin Sheng, and Clroud, 1984 ).

Apparently, non-specifle stimull can induce the production of factors whlch are at least functlonally simllar to medlators produced as a consequence of interactions between Listerla, Listerla-1mmune T-cells, and macrophages, which might explaln why even rather exotic substances can enhance the reslstance of experimental andmals towards L1sterla.

\section{M11ing of Listerla monocytogenes.}

Heactive oxygen metabolites.

Several studies have been dedicated to the possible involvement of reactive oxygen metabolltes (Plck and Kelsarl, 1981; Halliwel, 1982) In the limination of Listerla. Virulent stralns of Llsterla monocytogenes were found to be catalase-postelve and contalned relatively high levels of superoxide dismutase (SOD). stralns contalnding only a high level of SOD and a catalase-positive strain contalning a relatively low level of soD were avirulent. Furthermore, in vivo virulence appeared to be assoctated with reststance towards a superoxide generating systen in vitro (Welch et al., 1979). These observattons suggest that the contributton of reactive oxygen products to the ellatnation of Listerla might be restricted to relatively avirulent strains.

Lititer La-immune antigen-ellclted (LIAE) macrophages (obtalned 
by immunization of mice with viable Listerla and elfcitation of macrophages with killed bacterla) showed enhanced chemiluninescence as compared to control cells upon stimulation with opsonized Listeria or opsonized zymosan (Godfrey and W11der, 1984). Opsonized zymosan also stimulated the rellease of superoxide $\left(02^{-}\right)$and hydrogen peroxide $\left(\mathrm{H}_{2} \mathrm{O}_{2}\right)$ by LIAE-macrophages. However, only mLimall amounts of $\mathrm{O}_{2}^{-}$and $\mathrm{H}_{2} \mathrm{O}_{2}$ were generated upon stimulation of macrophages with either viable or killed, virulent or avirulent, opsonized Listerla. Furthermore, scavengers of oxldatlve metabolites only had a minimal effect on the bacterlcidal activity of activated macrophages (Godfrey and W11der, 1984). Godfrey and W11der suggested that chemilumescence in the absence of demonstrable $\mathrm{H}_{2} \mathrm{O}_{2}$ release might be due to the peroxidase catalyed production of hypochlorous actd (from $\mathrm{H}_{2} \mathrm{O}_{2}$ and $\mathrm{Cl}$ ) whlich in turn acts upon the chendluminescence substrate (1umino1). Subsequent1y, 1 was found that virulent strains of Llsteria produced substantal amounts of $02^{-}$and $\mathrm{H}_{2} \mathrm{O}_{2}$ in vitro, whereas only mintmal amounts were produced by an avirulent strain. Virulent stralns survived Intracellularly in resident macrophages, whereas most bacteria of an avirulent strain did not. As addition of exogenous $\mathrm{H}_{2} \mathrm{O}_{2}$ resulted in a signiflcant loss of macrophage viability, it was suggested that reactive oxygen metabolites might contribute to the pathogenesis and pathology of 11sterial infection. On the other hand, the deleterious effects of Listeria-derived oxygen metabolltes might be counteracted by serum protelns, as opsonized Listerla produced less $\mathrm{O}_{2}^{-}$and $\mathrm{H}_{2} \mathrm{O}_{2}$ than unopsonized bacterlat (codfrey and W11der, 1985).

In sumary, while several reports indicate that reactive oxygen metabolites might contribute to the elimination of other Intracellular bacteria such as Mycobacterlum lepraemurHum, Mycobacterium leprae, Mycobacterium tuberculosis, and Leglonella pneumophila (Stach et al., 1984; Sharp, Colston and Banerjee, 1985; toffuan, Pine and Bell, 1983), they are probably not essentlal for the elinination of Listeria. 
Other bacterleddal and bacteriostatle factors

Upon treatont wh lymphokines Cobtained from the serum of Liacerta-limine antmals after injection of Listerla-antigem), hamster perttoneal macrophages secreted a factor which Inhiblted the growth of Llsteria (Dumont, 1978).

Caselnate-eltcited perttoneal exudate cells from BCG-1nfected gulnea plgs produced a 1 stertcldal factor upon stimulation wth PPD (purlfled proteli derlvative). The 1lsterteldal product had the characterlatics of a cationic protein. It was relatively heatstable, non-dlalysable, and antagonlzed by polyantons and iron Lons It adsorbed reversibly to cellulose nitrate but was irreverstbly bound by glass and catlon-exchangers. The Histericldal proteln was also active against Corynebacterium pseudodiphteriticum and Bac111us subt111s, but not agalnst a number of other organiams (Shama and Middlebrook, 1977). Prevlously it had been shown that the 11 sterlicldal proteln was produced as a consequence of Interactlons between BCG-1mmune 1 ymphocytes and macrophages (M1ddlebrook, S⿴lmon, and Krelsberg, 1974). Actlvated gulnea pig macrophage monolayers which secreted listericldal products showed only minimal uptake of radiolabeled Listeria (Bast et al, 1974; Middlebrook et a1., 1974). Also Ilsteria-imune murine peritoneal macrophages released coluble listericldal products upon in vitro stimulation with killed Llsterla (Sethi, Teschner, and Brandis, (1974).

Davlles (1983) reported that actlvated rat macrophages killed Listeria In vitro whout concommittant release of extracellular 1Ltertcldal producto. However, 11stertcidal protelms might also be deltvered to phagosomes wthin whtch Llsterla resides after phagocytosts by macrophages. In fact, tatracelilular secretion of 11sterteldal proteln would be expected to result in higher concentrations of listerteldal products and hence more efflclent kil11ng of Listeria than extracellular secretion of 1 istericidins.

The listerteldin from gulnea plg peritoneal exudate cello (Sharma and Middlebrook, 1977) was suggested to be related to the platelet-derived 1istericidin which is present in rat serum (Czuprynskl and Ballsh, 1981a). In the latter study, also rabbit 
serum was found to have Hsterictdal activity Hamster, gutnea plg, beagle, human and mouse sera, however, were not listericlda. Llsterla reduced the recalcifled clotting time of citrated platelet-rich rat plasma, indlcating that the organisw can exhibit procoagulant activity (Davies, Ackerman and Nelson, 1981). Live Listeria Induced platelet-aggregation in platelet-rteh rat plasma, but formalinized bacterla were much less effective treatment of platelet-rich plasma with $A D P$ or of washed platelets wth thrombin resulted in the release of listericidal activity from the platelets. However, incubation of Listerla with platelet-rich plasma did not k111 the bacterla (Czuprynskl and Bal1sh, 1981b), ind lcating that completion of the clotting process may be required for release of listericidal activity. On the other hand, Incubation of platelet-rich plasma with Listerla did promote the release of dense granules, which was weasured as serotonln-xelease. Therefore, it was suggested that platelet alpha or lysosomal granules might be the storage site of the platelet-1istericldin (Czuprysnki) and Balish, 1981b). Optimal expression of platelet-derived 1Lsericidal activity was found to require a plasma cofactor (Czuprynski and Ba11sh, 1981 b; Davles et al., 1981). Rabblt plateLets enhanced the postphagocytic destruction of Listerla in cultured mouse peritoneal macrophages. Mouse platelets, however, we re reported to be considerably less effectlve (W11der and Lubin, 1973). Also the phagocytasis of Listeria by platelets has been deserlbed: (Absolom et a1., 1982).

Garro11 and Martinez (1981, a, b, c) deacribed the purlfication of a platelet-derived low hH cationic proteln from rabblt berum. The bacterlcidal proteln was actiwe agalnat Bacl11us subt11s, Listerta monocytogenes, Escherichia coll and salmonella typhis murlum, and found to Inhibit microblal electron transport.

The clotting system has also been Implicated in the expresion of delayed-type hypersensivity, as 1 yaphokines were found to enhance macrophage procoagulant activity, which in turn promotes the deposition of fibrin at the ste of a DrH-reaction focay, $1983)$.

Lehrer et a (1983) and Selsted, szklarek and Lehrer (1984) 
studled the anttintcroblal activity of low MW catlonic peptides fron rabblt macrophages and granulocytes, respectively. Peptide antiblotics from both gourees were active against a broad spectrum of bacteria, includ lng Ly monocytogenes. Catlonlc protelas were 1.180 shown to function as opsonins for group A streptococci and Candlda alblcans (G1nsburg et a 1, 1981) and to lnduce autolytlc enzymes in staphylococcus aureus (GIasburg, Lahav, and Glesbrecht, 1982), but whether these properties of cattonlc protelns are relevant for the elimination of Ligteria has not been established.

Theoret lcally, also acyleting enzymes might contribute to the elimination of Listerla as Lloterla-peptidoglycan, whlch is resistant to Iysozyme due to the presence of free amino groups, became sensitive to 1ysozyme-treatment after acetylation (Kamisango et a1., 1982).

In conclusion, cationic protelns might be of prine lmportance for the expression of natural and acquired reslstance against Listerla.

Reactive oxygen products whit contribute to the elinination of Lloterla in an Indirect way, because the Iistertcldal product described by Midlebrook et al. (1974) was Inactlvated by the reduclng agent dithlothreftol and partlally reactivated by $\mathrm{H}_{2} \mathrm{O}_{2}$. Furthermore, optimal production of 11stericidal actlvity required the use of $\mathrm{H}_{2} \mathrm{O}_{2}$ - treated medium. In other studies the bacterium Itself may have generated $\mathrm{H}_{2} \mathrm{O}_{2}$ (Godfrey and w11der, 1985), thus contributing to Its own elimination.

\section{LLeterta-vacel nee}

While enhanced resistance agalust listecla $1 \mathrm{~s}$ easily induced Wth a sublethal dose of viable bacterla, results of attenpts to Imantze animals with killed bacterla thave been rather disappolnting (seellger and Finger, 1976). Medina et al. (1975) reported that $657 \mathrm{BL} / 6 \mathrm{~J}$ mice could be protected against Listerla Infection wth a phenol-killed Listeria waccine. However, lin this straln of Wee enhanced resistance agalnst Llsteria was also observed after treatment with substances bearing no known antigenic relationshlp to Listerla, Indlcating that also the protection Induced with 
killed Listeria may have been due to a nonspectfic anhancement of host resistance, rather than to induction of $\mathrm{l}$-cel1-dependent immunit $y$.

According to Van Dijk et a1. (1980), C3H/HeJ, but not c3HeB/feJ or BALB/c mice, could be protected agalnst Listerla infection by immunization with heat-k11Led bacterla. In comparison with BALB/C and $C 3 H \mathrm{H} B / \mathrm{FeJ}$ mice, C3H/HeJ mice were found to have relatively high serum concentrations of a polyanionic substance, which was precipitated by protamin sulphate. As polyanioms (suramin and dextran sulphate) had been found to be effective adjuvants for kiled Listeria vaccines (Van der Meer et al, 1977), Van Dijket a1. (1980) suggested that the polyanionic serum factor of $63 \mathrm{H} / \mathrm{HeJ}$ wice might function as a kind of intrinsic adjuvant. Alternatively, the immunogenicity of killed bacteria $1 \mathrm{n}$ C.3H/HeJ mice might be related to the macrophage defect of these mice, nesulting in incomplete degradation of killed bacterla and preservation of imunogenic components (Van Dijk et al, 1980). However, Wirsing von Koenig, Finger and Hof (1982) suggested that the protection observed by Van der Meer et al. (1977) and Van Dijk et al. (1980) might have been due to the small number of viable bacterla left after heat treatment, which is insuffictent to lnduce protection in normal mice, but proliferates to an immunizing doge in mice having a natural (C $3 \mathrm{H} / \mathrm{HeJ}$ ) or artiflcially induced (dextran sulphate treatment) macrophage defect.

Multiple injections of a Listeria cell wall fraction (Rodrlguez, McClatchy and Campbe11, 1974) or of Listeria-hemolysin (KIngdon and Sword $1970 \mathrm{~b}$ ) Linduced some protection, but in generall use of adjuvants such as 1 tpopolysaccharlde (LPS) (Rodrlguez et a1. 1974), trehalose dimycolate (Le Garrec, Gale111 and Audibert; 1981) or dimethyldioctadecylamondum bromide (Van der Meer, Hothuis and Willers, 1979; Willers etal, 1979) appears to be required for the induction of substantial level of resiatance with killed or radiation-inactivated bacteria, or subcellular fractions of Listeria.

Adjuvants might mimic the deleterlous effect of viable Listeria on macrophages resulting in preservation of imunogentc componenta 
(W11ers et al. 1979). Conversely, this concept lmplles that vlable bacterla produce their own adjurant, which might be the hemolysin (KIngdon and Sword, 1970a) or amonla (Seellger and Flinger, 1976). Amonla has adjuvant propertles which were suggested to be related to lts 1 nhibltory effect on the complement system (Klerx, 1985). In addition, ammonla was found to lnhibit phagosome-1ysosome fuslon Ln macrophages (Gordon, D'Arcy Hart and Young, 1980). Also wth other adjuvants a correlation was found between adjuvant actlvity and anti-complementary effects (Klerx, 1985 ) or Inhibltion of phagosome-1ysosome fuston (Wllers et al., 1979). The umunoenhacling effect of at least some substances appears to be medlated by ILL (staruch and wood, 1983).

In a search for fmonogentc subcellular components of Listeria, Willers et a1. $(1979)$ found that the highest protective activity was locallzed in a phenol extract of the cell content of Listeria. In combination with DDA, 1 Hg of this fraction was sufficient to protect mice against 50 L050. As RNase-treatment completely destroyed t ts protect 1 ve properties, the subcellular vaccine of Willers et a1. (1979) apparently belongs to a class of RNasesensitive vacclnes the prototype of which is the RNase-sensitive ribosomal vaccline from Mycobacterlum tuberculosis described by Youmans and Youmans (1966). Extrapolating from results of experiments with metabollc Inhtbitors Youmans and Yowans (1974) hypotheslzed that mycobacterlaI RNA replicates in host cells in a manmer limilar to the replication of RNA tumor viruseo which Involves RWA-directed DNA synthesls. Youmans and Yownans (1974) speculated that replication of ycobecterial RNA might transform a host cell tnto a specifle lmmune cell. However, direct evidence for the replication of mycobactertal RNA In host cells ls lacking.

In studles with ribosomal vaccines from other organtsms (revlewed by Lisensteln (1978) and conggrijp et al. (1985)) ind cattons were found that RNA does not contrlbute to the Induction of protection (Cooper, Tewart and Bowser, 1980), may have an adjuwant function (Thompson and Snyder, 1971), or nonspecificaliy enhances host resistance. (Araujo and Remington, 1974). From studles of Medina et al. (1975) and Misfeldt and Johnson (1978) it 
has becone clear that differences in the strains of to used to evaluate the protective activity of subcellular vacclaes can be source of conflicting results with respect to the contribution of RNA to the Induction of enhanced resistance. On the other hand, Gonggrijp et al. (1980; 1981 a, b; 1983) showed that all three types of vaccine (RNase-sensitlwe/nonspeciflc, RNase-insensitive and RNA-adjuvated) could be prepared from Pseudomonas aeruglnosa. In these studies RNA-mediated effects were evaluated using DDA as an adjuvant, which might be another source of vartation.

Freund's incomplete adjurant (FIA) appeared to be a partlcularly effective adjuvant for the mycobacterlal RNA vacclne of Youmans and Youmans, whereas only a slight adjuvant effect was observed for several polybasic amines (Youmans and Youmans, 1972). On the other hand, nelther Listeria ribosomes in combination with FTA (Coppel and Youmans, $1969 \mathrm{~b}$ ), nor k11led Ltsterla In comblnation with Freund's complete adjuvant (FCA) (Van der Meer et al., 1979) protected mice agalnst 1isteriosis. These observations suggest that the speclftcity attributed to the protection induced with mycobacterlal rlbosomes plus FIA (which was partially based on the observation that mycobacterlal ribosomes plus flA did not protect mice agalnst listertosis) (Coppel and Youmans, 1969a) might be related to the use of FIA.

\section{Concl ud 1ng remarks}

Whereas the mechantsm of protection against 11 sterlosis luduced by Immunization with vlable Llaterta appears to have been largely elucldated, relatively $11 \mathrm{ttle}$ is known wh respect to the mechanism of protection Induced by non-viable Llsterta-vaccines in combination with aduvants. Subject of thls thes lo is the mechanism of protection Induced by subcellular preparations from Listeria monocytogenes combined with the adjuvant DDA. 


\section{BRELEENCES}

Abrolom, D.R., Francis, D.W., ZIngg, W., Van Oss, C.J., and Weumann, A.W. 1982. Phagocytosis of bacterla by platelets: Surface thermodynamics. J. Collold Interface Sclence 85 , $168-177$.

Ada, G.L., Leung, K. -H., and Ertl, H, 1981, An analysts of effector $\mathrm{l}$-cell generation and function $1 \mathrm{n}$ mice exposed to Influenza A or Senda1 viruses. Immunological Rev. 58, 5-24. Araujo, F, G\%, and Bemington, J.S. 1974. Protection against Toxoplasma gond11 in mice Immunized with Toxoplasma cell fractions, RNA and synthetic polyribonucleotldes. Immunology $27,711-721$.

Baker, L.A., and Campbe11, P.A. 1978. Listerla monocytogenes ce11 walls induce decreased resistance to Infection. Infect. Immun . 20, 99-107.

Bakker-Woudenberg, I.A.J.M., Lokerse, A.F., Roerdlnk, F.H., Regts, D., and Miche1, M.F. 1985. Free versus 11posome-entrapped apictiln in treatment of infection due to Listeria monocytogenes in normal and athymic (mude) mice. J. Infect. D1s: $151,917-924$.

Bakker-Woudenberg, I.A.J.M., de Bos, P., van Leeuwen, W.B., and Michel, M.F. 1981. Efflcacy of ampicillin therapy in experimental 1isterlosis in mice with impalred T-cell-mediated limmune response. Ant 1nlcrob. Agents Chewother. 19, 76-81.

Hat Ir., R.C., Cleveland, R.P., LIttman, B.H., Zbar, B., and Rapp, HoJ, 1974. Acquired cellular immunity. Extracellular klling of hlgterla monocytogenes by a product of immunologlca11y act Ivated macrophagee Ce11. Immunol, 10, 248-259. BLtd, J., JIn Sheng, I., and Giroud, J.P. 1984. Effects of supernatants and lysates of polymorphonuclear leucocytes: macrophage stimulatory factors. Br. J. Exp. Path. 65, 243-250.

Bloksma, N., De Reuver, M.J., and Wlllers, J.M.N. 1983. Impalred macrophage functions as a posstble basis of immunomodification by wicroblal agents, tilorone and dimethyldiactadecylammondum bromide, Antonle van Leeuwenhoek 49, 13-22. 
Burgaleta, C., and Golde, D.W. 1977. Effect of glucan on granulopolesls and macrophage genests in mlce. Cancer Research 37, $1739-1742$.

Carroll, S.F., and Martinez, R.J. 1981a. Antlbacterlal peptlde from nomal rabbit serum. 1. "Isolation from whole serun, activity and microbicidal spectrum. Blochetistry 20 , $5973-5981$.

Carro11, S.F., and Martinez, R.J. 1981b. Ant1bactertal peptide Erom normal rabbit serum. 2. Compositional meroanalysis * Biachem istry 20, $5981-5987$.

Carrol1, S.F., and Martinez, R.J. 1981c. Antlbacterlal peptide from nomal rabbit serum. 3. Inhlbition of microblal electron trans port. Bl ochem lstry $20,5988-5994$.

Chapes, S.K., and Haskill, S. 1983. Evidence for granulocytemedlated macrophage activation after C. parvum Immunlation. Ce11. Immunol: 75, 367-377.

Cheers, C., and McKenzle, I.F.C. 1978. Reslstance and susceptbility of mee to bactertal infection: genet1cs of listerlosis. Infect. Immun 19, 755-762.

Cheers, C., and McKenzle, I.F.C. 1983. Restriction in adoptive transfer of resistance to Listeria monocytogenes. I. Influence of non-H-2 1oc1. Ce11. Imuunol. 76, 304-310.

Cheers, C., and Sandrin, M.S. 1983. Restrlctlon in adoptive transfer of resistance to Lister1a monocytogenes. IT. Uate of congentc and mutant mlce show transfer to be $H-2 K$ restrlcted. Ce11. Tmano1. 78, 199-205.

Cooper, M.D., Tewart, R.P., and Bowser, D.V. 1980. Immunogentict ty of ribosomal preparations from Nelsserta gonorrhoeae. Infect. Imoun. $28,92-100$.

Coppe1, S., and Yourans, G.P. 1969a. Speciflclty of acquired resistance produced by fmmunization with mycobactertal cella and mycobacterlal fractions. J. Bact. $97,114-120$.

Coppel, S., and Youmans, G.P. 1969b. Specifletty of acquired resistance produced by limunlzation with LLsterla monocytogenes and 1isterla fractions, J. Bact. $97,121-126$. 
Cowart, R. E., and Eoster, B.G.. 1981. The role of fron 1n the production of hemolysin by Listeria momacytogenes. Current Merobtology $6,287-290$.

Czuprynsk , C.J., and Bellsh, E. 1981a, K1111ng of Llsterla monocytogenes by conventional and gemfree rat sera Infect. Immin. $33,348-354$.

Czupryngk1, C.J., and Bal1sh, E. 1981b. Interaction of rat platelets th LIsterla monocytogenes. Infect. Immun. 33, 103-108. Czuprynsk1, C.J., Henson, P.M.; and Cample11, P.A. 1984. K1111ng of Listeria monocytogenes by inflamatory neutrophils and mononuclear phagocytes trom immune and nonimune mice. J. Leuk: Blol. 35, 193-208.

Czupryank1, C.J., Canono, B.P., Henson, P.M., and Campbel1, P.A. 1985. Genet1cally determined resistance to listeriosis in assoclated Wth increased accumulation of inflammatory neutrophils and macrophages which have enhanced listericidal activity. Immunology $55,511-518$.

Catuprynskil, C.J., Henson, P.M*, annd Campbell, P.A. 1985. Enhanced accumulation of inflammatory neutrophils and macrophages mediated by tramsfer of T-cells from mice immunized with Lister la monocytogenes. J. Immunol. 134, 3449-3454.

Davies, W.A. Ackerman, V.P., and Nelson, D.S. 1981. Mechanlsm for nonspeciflc immuntey to Listeria monocytogenes in rats medlated by platelets and the clotting system. Infect. Immun. $33,477-481$.

Davies, W.A. 1983. Kinetics of k1111ng listerla monocytagenes by macrophages: Rapid k111ing accompanying phagocytosis. J. Ret. Soc $34,131-141$.

Dumont, A. 1978. Correlat1ve ultrastructural and functional study of hamster pertitoneal macrophage activation in vitro by Lymphokines. J. Ret. Soc. $24,317-332$.

Editorla1. 1980. Perinatal 14steriosis. Lancet 1,911,. Gisenteln, T.K. 1978. Ribosomal vaccines: review, p. 211-222. In: A. Voller and H. Frledman (eds.), New treads and deveLopments in vacclnes. MTP Press Ltd., St . Leonard Gate, England. 
Farr, A.G*, Kiely, J.-M., and Unanue, E.R. 1979a. Macrophage-TCell interactions involving Listerla monocytogenes - Role of the $\mathrm{H}^{-2}$ gene complex. J. Immunol. 122, 2395-2404.

Farr, A.G., Wechter, W.J., Kiely, J.-H., and Unanue, E.R. 1979 b. Induction of cytocidal macrophages after in vitro Luteractions between Listerla-Immune T-cells and macrophages - Role of H-2. J. Immunol. 122, 2405-241.2.

Farrar, J.J., Benjamin, W.R., H1lfiker, M.L., Howard, M., Farrar, W. L., and Fuller-Farrar, J. 1982, The biochemistry, blology, and role of interleukin 2 in the unduction of cytotoxic $T-$ cell and antibody formilng B-cell responses Immunaloglcal Rev. 63, 129-166.

Fauchère, J.L., Stmonet, M., and Véron, M. 1982. Non-spectfic resistance of mice to bacteria, induced by an acellular extract from Pseudomonas aeruglnosa, Ann Immunol. (Inst. Pasteur) $133 \mathrm{C}, 333-347$.

Fauve, R.M. 1971. Influence of synthetic polynucleotldes on the bacterlcidal power of mouse macrophages against Listerla monocytogenes. In: R.F. Beers Jr, and W. Braun (eds.). Biological effects of polynucleotides. Springer Verlag, New York:

Fleming, D.W., Cochi, S.L., MacDonald; K.L., Brondum, J., Hayes, P.S., Plikaytis, B.D., Holmes, M.B., Audurler, A., Broome, C.V., and Relngold, A.L. 1985. Pasteur1zed milk as a vehicle of infection in an outbreak of 11 sterlosis. New Engl. Whed. 312, $404-407$.

Flocth, H., Bouchaudon, J., Werner, G.H., Migllore-Samour, D., and Jo11ès, P. 1981. Enhancement by 1munostlaulating Ilpopeptdes of the non-specific resistance of mice to infection with Listerla monocytogenes. Ann. Immunol. (Inst. Pasteur) 132D, 265-270.

Fontan, E., and Fauve, R.M. 1983. Inflammation and host restetance to bacterla. III. Increased reslatance to Ligteria monocytogenes in mlce following injection of polyacrylamide microbeads. Ann. Immunol (Inst. Pasteur) 134C, 255-264. 
Fontan, E., Fawe, R.M., HevIn, B., and Jusforgues, H. 1983. Inmunostimilory wowse granuloma protetn. Proc. Nat. Acad. Sci. USA 80, 6395-6398.

Pulton, A.M., and Levy, J.G. 1981. The Induction of nonsperfic $T-$ suppresgor Iymphocytes by prostaglandin EL cell. Imanol. $59,54-60$.

Geczy, C.L. 1983. The role of clotting processes in the action of 1ymphokines on macrophages. Lymphokines 8 , 201-247.

Gervaid, F, Stevenson, M., and Skamene, H. 1984. Genetic control of resistance to Llsterla monocytogenes: Regulation of leukocyte Inflammatory responses by the Hc Iocus. I. Immuno1. 132, $2078-2083$.

Gery, I., Davles, P., Derr, J., Krett, N., and Barranger, J.A. 1981. Relationah1p between production and release of 1 ymphocyte-activating factor (Interleukin l) by murtne macrophages. I. Effects of varlous agents. Ce11. Immuno1. 64, 293-303.

Glnsburg, I., Lahav, M., and Gleabrecht, P. 1982. Effect of leucocyte hydrolases on bacterla. XVI. Activation by leucocyte factors and cationic abstances of autolytic enzymes in Staphylococcus aureus: Modulation by anlonic polyelectrolytes in relation to survival of bacteria in inflamatory exudates. Inflammation 6, 269-284.

Glnsburg, I., Sela, M.N., Morag, A., Ravid, Z., Duchan, Z., Ferne, M., Roblnowitz-Bergner, S., Page Thonas, P*, Davies, P., N1ccols, J.; Humes, J., and Bonney, R. 1981. Role of leucocyte factors and cationic polyelectrolytes in phagocytosis of group A streptococcl and Candlda alblcans by neutrophils, nacrophages, flbroblasts and eptthellal cells: Modulation by anionlc polyelectrolytes in relation to pathogenesis of chronle Inflammation. Inflamation $5,269-312$.

Godfrey, R.W., and W1Lder, M.S. 1984. Relatlonship between oxidative metabolism, macrophage activation, and antilisterlal actlvity. J. Leuk. B101. 36, 533-543.

Godfrey, R.W., and W11der, M.S. 1985. Generation of oxygen species and virulence of Listerla monocytogenes. Infect. Immun. 47, 837-839. 
Gongrrijp, R., Antonlssen, A.C.J.M., Van dea Bosch, J.F, and Van Boven, C.P.A. 1984. Ribonuclease-sensttive ribosomal vaccines. Antonie yan Leeuwenhoek $50,763-774$.

Gonggrijp; R., Mullers, W.J.H.A. Lemmens, P.J.M.R., and Van Boven, C.P.A. 1980. Kibonuclease-sensteive ribosomal vaccine of Pseudomonas aeruginosa. Infect. Immun. 27, 204-210.

Gonggrijp, R., Mullers, W.J.H.A., and Van Boven, C.P.A. 198la. Serotype-nonspeciflc protection 1 nduced by ribonuclelc acld isolated from the ribosomal vaccine of Pseudomonas aerug inosa. Infect. Immun. 33, 178-185.

Gongerifp, R., Mullers, W.J.H.A., and Van Boven, C.P.A. 1983. Pratective activities of ribosomal ribonuclelc actd and 11 popolysaccharlde of Pseudomonas aeruglnosa: a comparative study. Antonie van Leeuwenhoek 49, 173-182.

Gonggrijp, R., Volleberg, M.P.W., Lemmens, P.J.M.R., and Van Boven, C.P.A. $1981 \mathrm{~b}$. Evidence for the presence of 11 popolysaccharlde in a ribonuclease-sensitive ribosomal vaccine of Pseudomonas aeruglnosa. Infect. Immun. 31, 896-905.

Gordon, A.H., D'Arcy Hart, P., and Young, M.R. 1980. Ammonia inhibits phagosome-lysosome fuston in macrophages. Nature $286,79-80$.

Goto, K., Nakamura, S., Goto, F., and Yoshlnaga, M. 1984. Generation of an interleukin-1-11ke 1 ymphocyte stimulating factor at inflammatory sites: correlation with the lifiltration of pol ynor phonuclear leucocytes. Br. J. Exp. Path. 65, 521-532.

Gregorio and Eveland. 1975. Isolation of Listerla monocytogenes

from Inapparent sources in MAchlgan, p. 87-93. In: M. Woodbine (ed.). Problems of Listeriosis - Lelcester University Press.

Hadibi, E. H*, Bastlde, M., and Bastide, J.H. 1981 . Effet protecteur d"un extralt parietal de Plchle fermentans contre les infections a Klebsiella pneumotiae et Listerla monocytogenes. C.R. Acad. Sc. Parls 293 (Serte III), 119-122.

Hahn, H., and Kaufmann, S.H.E. 1981. The role of cell-mediated immunity in bacterlal infections. Rev. Infect. D1s. 3, 1221-1250. 
Hahn, H. and wather, 1984. Protection agalnst facultative Intracellular bacteria - Role of macrophage activation and granuloma formation. Infection 12,131 .

Ha111we1, B. 1982. Hypothests: Production of superoxide, hydrogen peroxide and hydroxyl radlcals by phagocytic cells: A cause of chronlc inflamatory disease? Cel1. Blol. Int. Rep. 6, $529-542$.

Ham uro, J. Rollinghof, M., and Wagner, H. 1978. $\beta(1-3)$ glucanmediated augmentation of alloreactive murine cytotoxic $T$ 1yimphocytea in vivo. Cancer Reaearch 38, 3080-3085.

Harr1ngton-Fowler, L., Henson, P.M., and WLlder, M.S. 1981. Fate of Listerla monocytogenes. In resident and activated macrophages. Infect, Immun. 33, 11-16.

Hof, H., Emmerling, P., and H.P.R. Seellger. 1981. Murine model for therapy of 1 istertosis in the compromised host. I. Effect of ampict11in. Chemotherapy $27,214-219$.

Hof fman, P.S., Plne, L., and Bel1, S. 1983. Production of superoxide and hydrogen peroxide in medium used to culture Legionella pneumophila: Catalytic decomposition by charcoal. Appl. Environ. Mcroblo1. 45, 784-791.

Holder, I.A., and Sword, C.P. 1969. Characterization and blologlcal activity of the monocytosis-producing agent of Listeria monocytogenes. J. Bacteriol, 97, 603-611.

Howard, A.J., Kennard, C., Eykyn, S., and Higgs, I. 1981. LIsterial infections of the central nervous system in the previous ly heat thy adult. Infection $9,80-84$.

Hyslop, N.St.G. 1975. Epldemiologlc and tmanologle factors in 11steriosts, p. 94-105. In: M. Woodbine (ed.), Problems of Listeriogis - Lelcester University Press.

Jin Sheng, Y*, Fllorentin, 1., Blrd, J., Esnous, D., Pompldou, A., and Giroud, J.P. 1982. The enhancement of interleuk1n-2-11ke production after In wivo stimulation of rat lymphotd cells by an acute nonspeciflc Inflamatory process. Blomedicine 36 , $436-440$ 
Jungi, T.W., G111 III, T.J., Kunz, H.W., and JungI, R.. 1982. Genetic control of cell-medlated Immity in the rat. III. Tcells restricted by the RT1.: A lacus recognize viable Listeria but not isolated bacterlal antigens. J. Inmunogenetics $9,445-456$.

Jungi, T.W., and Jungi, R. 1982. Genetic control of cell-mediated immunity in rats: Involvement of RT 1. B locus determinants in the proliferative response of $T$ lymphocytes to Listeria antigens. Infect. Immun. 38, 521-529.

Kamisango, K., Saiki, I., Tanio, Y., Okumura, H., ArakL, Y., Sekikawa, I., Azuma, I. and Yamamura, I, 1982, Structures and biological activities of peptidoglycans of Listerta monocytogenes and Proplontbacterium acnes. J. Blochem. 92, $23-33$.

Kampelmacher, E.H., Huysinga, H.Th., and Van Noorle Jansen, L.M. 1972. The presence of Listeria monocytogenes in feces of pregnant women and neonates. Zbl. Bakt. Hyg., I. Abt. Orfg. A $222,258-262$.

Kampelmacher, E.H., and Van Noorle Jansen, L.M. 1972. Further studies on the isolation of L. monocytogenes in clinically healthy individuals. Zbl. Bakt. Hyg •, I. Abt. Orig * A 221, $70-77$.

Kampelmacher, E.H., and Van Noorle Jansen, L. 1975. Occurrence of L. monocytogenes in effluents, p. 66-70. In: M. Woodbine (ed.). Problems of Listerlosis - Leicester University Press. Kampelmacher, E.H., and Van Noorle Jansen, M. 1979. Listerlose bij mens en dier in Nederland (1958-1977). Ned. T. Geneesk. 123, 557-564.

Kaufmann, S.H.E. 1983. Effective antibacterial protection induced by a Llsterla monocytogenes - specific T-cell clone and $1 \mathrm{tg}$ 1youphokines. Infect. Immun. 39, 1265-1270.

Kaufmann, S.H.E., and Hahn, H. 1982. Blologlcal functions of $T-$ cell lines with spectifcity for the intracellular bacterlum Listeria monocytogenes in vitro and in vivo.j. Exp. Med. $155,1754-1765$. 
Kaufmann, S.H.E., Hahn, H., Berger, H., and Kirchmer, H. 1983. Interferon $\gamma$ production by Listerla monocytogenes-specific $\mathrm{T}$-cells active in cellular antibacterial 1manity. Eur. J. Inmunol. 13, 265-268.

Kaufmann, S.H.E., Hahn, H., Simon, M.M., Rollinghoff, M., and Gagner, H. 1982. Interleukin-2 induction in Lyt $1^{+} 23^{-} \mathrm{T}$-cells from Listerla monocytogenes-immune mice. Infect. Immun. 37, $1292-1294$.

Kaufmann, S.H.E., Hug, E., Vâth, U., and Miiler, I. 1985. Effective protection agalnst Listeria monocytogenes and delayedtype hypersensitivity to listerial antlgens depend on cooperation between speciflc $\mathrm{L} 3 \mathrm{~T}^{+}$and $\mathrm{Lyt} 2^{+} \mathrm{T}$-cells. Infect. Immun * 48, $263-266$.

Kaufmann, S.H.E., Slmon, M.M., and Hahn. 1979. Speciflc Lyt 123 Tcells are $\mathbb{1}$ suolved in protection against Listeria monocytogenes and in delayed-type hypersensitivity to listerlal antigens. J. Exp. Med. 150, 1033-1038.

Kaufmann, S*H.E., Simon, M.M., and Hahn, H. 1982. Regulatory Interactions between macrophages and $\mathrm{T}$-cell subsets in Listerla monocytogenes-spectfic T-cell activation. Infect. Immun. $38,907-913$.

Kawaler, B., and Hof, H. 1984. Fallure of cephalosporins to cure experimental 1isteriosis. J. Infect. Dis. 9, 239-243.

K1derlen, A.F., Kaufmann, S.H.E., and Lohmann-Matthes, M. -L. 1984. protection of milee agalnst the intracellular bacterium Llsterla monocytogenes by recombinant Iminue Interferon. Eur. J. Immunol. 14, 964-967.

Kingdon, G.C., and Sword, C.P. 1970a. Effects of Listerta monocytogenes hemolysin on phagocytic cells and lysosomes. Infect *Immun. 1, 356-362.

Kingdon, G.C., and sword, C.P. 1970b. Biochemtcal and Lmmunologlcal effects of Listeria monocytogenes hemolysin. Infect. Iminun. 1, 363-372.

Klngdon, G.C., and Sword, C.P. 1970 C. Cardotox1c and lethal effects of Listeria monocytogenes hemolysin. Infect "Immun. 1. 373-379. 
Klerx, J.P.A.M. 1985. Immunologlcal adjuvant activity: complement-dependent and Independent processes. Ph.D.: thesis, University of Utrecht, The Netherlands.

Ledbetcer, J.A., Rouse, R.V., Mickler, H.S., and Herzenberg, L.A. 1980. T cell subsets defined by expression of Lyt-1, 2, 3 and Thy-1 antigens. Two-parameter tmmunofluorescence and cytotoxicity analysis with monoclonal antibodies modifles current views. J. Exp. Med. 152, 280-295.

Le Garrec, X., Galelli, A*, and Audibert, F. 1981. Induction of resistance to Listeria monocytogenes In mice treated with al combination of inactivated bacteria potentlated by tretralose dimycolate. Ann. Immuno1. (Inst. Pasteur) 132D, 271-280.

Lehrer, R.I., Selsted, M.E., Szklarek, D., and Flelschmamn, J. 1983. Antibactertal activity of microbicldal cationic proteins 1 and 2, natural peptide antibiotics of rabbit 1 ung macrophages. Infect. Immun. $42,10-14$.

MacGowan, A.P. Peterson, P.K., Keane, W., and Qule, P.G. 1983. Human peritoneal macrophage phagocytic, killing, and chemiluminescent responses to opsonized Listeria monocytogenes. Infect. Immun. 40, 440-443.

Mackaness, G.B., 1962. Celular resistance to infection. J. Exp. Med. $116,381-406$.

Mackaness, G.B. 1969. The influence of Lmmologlcally comitted 1 ymphoid cells on macrophage activity In vivo. J. Exp. Med. $129,973-992$.

Mackaness, G.B. 1970. The monocyte in delayed hypersensitivity. p. 478-484 In: R. Wan Furth (ed.) Mononuclear phagocytes. Blackwe11 Sclentiflc: Publications, Oxford.

Mandel, T.E., and Cheers, C. 1980. Resistance and susceptiblitty of mice to bacterial infection: Histopathology of 1istertosis in resistant and susceptible strains. Infect. Inmun. 30 , $851-861$.

McCallum, R.E., and Sword, C.P. 1970. Mechantsins of pathogenests in Llsteria monocytogenes infection IV. Hepatic carbohydrate metabolism and function in experimental listeriosis. Infect. Imonun. 1, 183-189. 
MeCaL1um, R.E., and sword, C.P. 1972a. Mechaniswe of pathogenesis in Listerla monocytogenes Infection: $\%$. Barly imbalance In host energy netabollsa during experimental listeriosis. Infect. Immun , 5, 863-871.

Mecallum, R.E., and sword, C.P. 1972b. Mechanlsms of pathogenesis In Listerla monocytogenes Infectlon: VI. Oxidative phosphorylation in mouse liver mitochondria during experimental 11stertosts. Infect. Immun. 5, 872-878.

Medna, S., Vas, S.I., and Robson, H.G. 1975. Effect of nonspectfic stimulation on the defense mechanisms on inbred mice. J. Immunol. 114, 1720-1725.

Middlebrook, G., Salmon, B.J., and Krelsberg, J.I. 1974. Ster111zation of Listerta monocytogenes by guinea plg perttoneal exudate cell cultures. Ce11. Immunol. 14, 270-283.

Miffeldt, M.L., and Johnson, W. 1978. Protective ability of Salmonella ribosomal protern and RNA in lnbred nice. Infect. Iminun. $21,286-291$.

MLtsuyama, M., Takeya, K., Nomoto, K., and Sh1motori, S. 1978.

Three phases of phagocyte contribution to resistance agalast Listeria monocytogenes. J. Gen. Microblol. 106, 165-171. Miyata, M., Mtesyama, M., Ogata, N., Nomoto, K., and Takeya, K. 1982. Two steps in the generation of acquired cellular resistance against Listeria monocytogenes: accumulation and act1vation of macrophages. Immunology, 47, 247-253.

Murray, H.W. Spltalny, G.L., and Nathan, C.F. 1985. Activation of motise perltoneal macrophages $\ln$ vitro and in vivo by Interferon $\gamma$. J. Immunol. 134, 1619-1622.

Naher, H., Sperling, U., and Hahn, H. 1984. Developmental interrelationship of spectflc Lyt 123 and Lyt1 cell sets in expression of antibacterial immunty to Listerla monocytogenes. Infect. Immun. 44, 252-256.

Nather, H., Sperling, J., and Hahn, H. 1985. H-2K-restricted granuloma formation by $\mathrm{Ly}-2^{+} \mathrm{T}$ cells in antibacterial protection to facultative intracellular bacterla. J. Immunol. 134, $569-572$. 
Nakane, A., and Minagawa, T. 1984. The signifleance of alpha/beta interferons and gamma interferon produced in mice Infected with Listeria wonocytogenes. Ce11. Immuno1. 88, 29-40.

Nathan, C.F., Murray, H.W., Wiebe, M.E., and Rubln, B.X. 1983. Identification of interferon- $\gamma$ as the lyophokine that activates human macrophage oxidative metabolism and antimicroblal activity. J. Exp. Med. 158, 670-689.

Nickilin, S., and Shand, F.L. 1982. Abrogation of suppressor cell function by inhibitors of prostaglandin synthesis. Int. I. Immunopharmacol. 4, 407-414.

Nieman, R.E., and Lorber, B. 1980. Listeriosis in adults: A changing pattern. Report of eight cases and review of the 11terature 1968-1978. Reviews of Infectlous Diseases 2, $207-227$.

North, R.J. 1973. Cellular mediators of anti-Listerla immunity as an enlarged population of short-lived, replicating $T$ cells. Kinetics of their production. J. Exp. Med. 138, 342-355.

North, R.J., and Spitalny, G. 1974. Inflammatory 1ymphocyte in ce11-mediated antibacterial immunlty: Factors governing the accumulation of mediator $T$ cells in peritoneal exudates. Infect. Immun. 10, 489-498.

Parant, M.A., Aud 1 bert, F.M., Chedid, L.A., Level, M.R., Lefrancier, F.L., Choay, J.P., and Lederer, E. 1980. Immunostimulant activities of a lipophilic muramyl dipeptide der vative and of desmuramyl peptldolipid analogs. Infect. Immun. $27,826-831$.

Parant, M*A.; Parant, F.J., and Ched1d, L.A. 1980. Enhancement of resistance to infections by endotoxid-induced serum factor from Mycobacterlum bovis BCG-Infected mice. Infect. Inmun. $28,654-659$.

PLck, E., and Kelsari, Y. 1981. Superoxide anlon and hydrogen peroxide production by chemically elicited peritoneal macrothages - Induction by multiple nomphagocytic stimul1. Cell. Inmunol. $59,301-318$.

Relier, J.P. 1979. Llsterios1s. J Antimlerob. Chemother. 5 (Suppl. A), 51-57. 
Rodr1guez, G.E., McClatehy, J.K., and Campbell, P.A. 1974. Inducthon of resfstance by Listerla monocytogenes cell wall fraction. Infect. Imman. 10, $1163-1169$.

Seeliger, H.P.R., and Finger, H. 1976. Listerlosis. p. 333-365. In: RemIngton, J.S., and KIeIn, J.0. (eds.). Infectious diseases of the fetus and newborn infant. W.B. Saunders Company. Phtladelphia.

Seel1ger, H.P.R. and Hokne, R. 1979. Serotyping of Llsterla monocytogenes and related spec1es, p. 31-49 In: T. Bergan and J.R. Norris (eds) Methods in Microbiology vol: 13, Acadenic Press, London.

Selsted, M.E., Szklarek, D., and Lehrer, R.I. 1984. Purification and antibacterial activity of antimicrobial peptides of rabblt granulocytes. Infect. Immun. 45, 150-154.

Seth1, K.K., Teschner, M*, and Brandis, H. 1974. In vitro ant111 sterial activity of soluble product(s) released from Listeria-immune murine peritoneal macrophages. Infect. Immun. $10,960-962$.

Sharma, S.D., and Middlebrook, G. 1977. Partial purification and properties of an antibacterial product of peritoneal exudate ce 11 cultures from BCG-infected gullnea-pigs. Infect. Immun. 15, $737-744$

Sharp, A.K., Colston, M.J., and Banerjee, D.K. 1985. Suscept1bilty of Mycobacteriun leprae to the bacterlcidal activity of mouse pertconeal macrophages and to bydrogen peroxide. J. Gen. Microblol. 19, 77-84.

Sperling, U., Kaufmann, 3.H.E., and Hahn, H. 1984. Production of iacrophage-activating and migation-inhibition factors in vitro by serologlcally selected and cloned Listerla monocytogenes-spectflc $\mathbb{T}$ cells of the Lyt $\mathrm{I}^{+} 2^{-}$phenotype. Infect : Immin. $46,111-115$.

Stach, J.L., Delgado, G., Tchlbozo, V., Strobe 1, M*, and Lagrange, P.H. 1984. Watural tesistance to mycobacterta: Antimicrobial actllity and reactive oxygen intermedlace releasing functions of murine macrophages. Ann. Immunol. (Inst. Pasteur) 135D, $25-37$. 
Staruch, M.J., and Wood, D.D. 1983. The adjuvantictty of InterLeukin $1 \mathbb{1 n}$ vivo. J. Immunol. 130, 2191-2194.

Stevenson; M.M., Kongshavn, P.A.L., and Skanene, E. 1981. Genetic inkage of resistance to Listerla monocytogenes with macrophage inflaminatory responses. J. Immunol. 127, 402-407.

Swain, S.L., Dialynas, D.P., Fitch, F.W*, and English, M. 1984. Monoclonal antibody to L3T4 blocks the function of $\mathrm{T}$ cells specific for class 2 major histocompatibility complex antigens. J. Immunol. 132, 1118-1123.

Sword, C.P. 1966. Mechanisms of pathogenesis in Listeria monocytogenes infection I. Influence of 1ron. J. Bacteriol. $92,536-542$.

Sword, C.P. and W11der, M.S. 1967. Plasma enzyme changes 10 Listeria monocytogenes infected mice. $J$. Infect. Dis. 117, $387-392$.

Tatsukawa, K., Mitsuyama, M., Takeya, K., and Nomoto, K. 1979. Differing contribution of polymorphonuclear cells and macrophages to protection of mice against Listerla monocytogenes and Pseudomonas aeruglnosa. J. Gen. Microblol. 115, 161-166.

Thompson, H.C.W., and Snyder, I.S. 1971. Protection againat pneumococcal infection by a ribosomal preparation. Infect. Immun. $28,92-100$.

Traub, W.H. 1981. Peritoneal 11steriosis. Tolerance of a clinical isolate of Listeria monocytogenes for amplcillin and resistance against cefotaxime. Chemotherapy, $27,423-431$.

Unanue, $\mathrm{E}, \mathbb{R}$. 1981. The regulatory role of macrophages in antigenic stimulation. Part two: Symblotic relationship between lymphocytes and macrophages. Adv. Immunol. 31, 1-136.

Van der Meer, C., Hofhuls, F.M.A., and Willers, J.M.N. 1977. Killed Listeria monocytogenes vaccine becomes protective on addition of polyanions. Nature, 269, 594-595.

Van der Meer, C., Hofhuis, F.M.A., and W111ers, J.M.N. 1979. Delayed-type hypersensitivity and acquired cellular reistance in mice Immunized wh killed Listeria monocytogenes and adjuvants. Immunology $37,77-82$. 
Van Dijk, H., Hofhulb, B.M.A., Berns, E.M.J.J., Van der Meer, C., and W11ers, J.M. 1980. K1lled Llstertla monocytogenes vacclne is protective in c3H/HeJ mice whout addition of adjuvants. Nature, $286 ; 713-714$.

Wednberg, E.D. 1971. Role of 1ron In host-paraste interactions. I. Infect. D1s, $124,401-410$.

Weinberg, D.S., and Unanue, $L . R$. 1981. Antfgen-presenting function of alveolar macrophages: Uptake and presentation of Listeria monocytogenes. J. Immuno1. 126, 794-799.

Weis, J:, 1975. The Incidence of Libterla monocytogenes in domestic and id antmals in South-West Germany. p. 121-126 In: W. Woodbine (ed) Problems of Listeriosis - Leicester University Press.

Welch, D.l ", Sword, C.P., Brehm, S., and Dusanic, D. 1979. Relationshlp between superoxide dismutase and pathogentc mechanLsms of L1ster1a monocytogenes. Infect. Immun. 23, 863-872.

WHO Sctentifle Group. 1973. Cell medlated immunity and resistance. WHO Techn. Rep. Ser. 519, 6-64.

WiggIns, G.L., Albritton, W.L., and Feeley, J.C. 1978. Antibiotic susceptibility of clinical 1solates of Listeria monocytogenes. Antimicrob. Agents Chemother., 13, 854-860. Wilder, M.S., and Sword, C.P. 1967a. Mechanisms of pathogenesis in Listeria monocytogenes infection II. Characterization of Literlosis in the CD-1 mouse and survey of blochemical lestons. J. Bacteriol. 93, 531-537.

Wilder, M.S., and Sword, C.P. $1967 \mathrm{~b}$. Mechanisms of pathogenesis in Listerla monocytogenes infection III. Carbohydrate metabo11sm. J. Bactertol, 93, 538-543.

Wilder, M.S., and Lublin, D.J., 1973. Platelet-enhancement of postphagocytic destruction of Listerta monocytogenes in cultured mouse peritoneal macrophages. Infect. Immun. 8, $843-845$.

WHLlers, J.M.N., Bloksma, N, Van der Meer, C., Snlppe, H., Van DIfk, H., De Reuver, M.J., and Hofhuis, F.M.A. 1979. Regulation of the fmune response by macrophages. Antonie van Le uweahoek, 45, 41-48. 
Wirsing von Koenig, C.H., Finger, H., and Hof, H. 1982. Fallure of killed Listeria monocytogenes vaccine to produce protective immunity. Nacure, $297,233-234$.

Youmans, A.S., and Youmans, G.P. 1966. Effect of trypsin and ribonuclease on the imunogenic activity of ribosomes and ribonucleic acid isolated from Mycobactertum tuberculosis. J. Bacteriol., $91,2146-2154$.

Youmans, A.S., and Youmans G.P. 1972. Effect of polybasic amines on the 1mmonogenicity of mycobacterial ribonuclelc acid. Infect. Immun. 6, 798-804.

Youmans, A.S., and Youmans, G.P. 1974. The effect of metabolic Inhibitors and hydroxylamine on the immune response in mice to mycobacterlal ribonucletc acid vaccines. J. Immunol, 112, $271-284$.

Ziegler, K., and Unanue, E.R. 1979. The spectflc binding of Listeria monocytogenes-immune $T 1$ ymphocytes to macrophages $I$. Quantitation and role of $\mathrm{H}-2$ gene products. J. Exp. Med., $150,1.143-1160$.

Zlnkernagel, R.M., Althage, A., Adler, B., Blanden, R.V., Davidson, W.F., Kees, U., Dunlop, M.B.C., and schreffler, D.C., 1977. H-2 restriction of cell-mediated 1mmuntey to an intraceliular bacterium. Effector $T$ cells are specific for Listerla antlgen in association with H-2I reglon-coded self markers. J. Exp. Med., 145, 1353-1367. 
CHAPIER 3

RMRAE-SEWSITIVE AWD RNA E-INSENSITIVE PROTECTIVE COMPONENTS ISOLATED FRON LISTERTA MONOCYTOGENES

\section{SUMMAKY}

Crude ribosomes were isolated from Listerla monocytogenes serotype $4 \mathrm{~b}$ and separated into two fractions by molecular sleve chromatography. Chemical analysis indicated that fraction 1 contalned cell envelope components while fraction II contalned the ribosomes. Both fractions protected mice against Listerla, but only in combination with the adjuvant dimethyldioctadecylammonium bromide (DDA). RNase-treatment, but not proteinase K-treatment destroyed the protective properties of fraction II, and RNA pur1fied from fraction II also induced protection. Protection induced by fraction I was not affected by either RNase- or proteinase Ktreatment. Both subcutaneous and intraperttoneal, but not intravenous admintistration of fraction $I$, fraction II, or purifled RNA induced signiflicant protection agalnst intraperitoneal infection, the intraperitoneal route of administration being the most effectLve. All preparatlons linduced high levelis of protection 3 to 7 days after administration, but protection was already decraased after 14: days. Protection induced with RAA appeared to be biphaste, because $1 t$ also protected mice 1 day, but not 2 days after administration. Protection induced with both fraction. $I$ and RNA was at least in part non-speciflc, because both preparations also protected milce against L. monocytogenes serotype 3 , streptococcus pneumoniae and Pseudomonas aeruginosa.

Results are discussed in relation to prevlous work with analogous preparations from $\mathrm{P}$. aeruglnosa. 
Listerla monocytogenes is a Gram-positive bacterium which behaves, when it has encered the body, as a facultative intracellular paraste. Its natural host cell ts the macrophage in which the organism 1 able to survive and even to multiply (Horld Health Organization Siclentific Group, 1973). Protection againgt experimental 1isteriosis can be lnduced with a sublethal dose of IIv ling bacterla (Mackaness, 1962), and is assumed to be due to $\mathrm{T}$-ciell mediated macrophage-activation (Cole, 1975). Induction of high levels of protection with killed bacterla or bacterial components requires the use of adjuvants such as lipopolysaccharlde (LPS) (Rodriguez et al., 1974), trehalose dimycolate (Le Garrec et 1. 1981) or the quaternary ammonium compound dimethyldioctadecylamonium bromlde (DDA) (Van der Meer et al., 1979; Willers et a1., 1979).

In an attempt to Identify the protective components of $L$. monocytogenes, Willers et al. (1979) Immized mice with fractions Lsolated from distupted bacteria. Using DDA as an adjuvant, highest protection was obtained with a phenol extract from the cell contents of the bacteria. Enzymatic treatment of this fracthon, which contalned 60\% nuclelc aclds, Indicated that RNA, but not DNA or protein was essential for the induction of protection.

previousily we described the separation of a crude ribosomal preparation from Pseudomonas aeruglnosa into Rase-sensitive and RNa e-insenstive protective components (Gonggrijp et al., 1980). In the present study we have investlgated whether the same puriflcation procedure would yield a simllar type of separation when applied to a crude rlbosomal preparation from $\mathrm{L}$. monocytogenes. $\mathrm{L}$. nonocytogenes wa chosen, because, in a sense, it is the opposite of P. aeruglnosa, a Gram-negative bacterium whtch behaves as an extracellular parasite (Peterson, 1980).

It was felt that the purification of ribosomal preparations from such disstillar organisms as $L$. monocytogenes and $\underline{P}$. aeruginosa according to a standardized procedure and comparison of thell protective propertles might lead to detection of a general 
principle with respect to the mode of action of ribosomal vaccines. Such a general principle has not yet been show, possibly due to varlations with respect to the puriflcation procedures used by different investigators (EIsenstein, 1978).

MATERIALS AND METHODS

Experimental animals

Male BALB/c mice were purchased from TNO, Central Institute for the Breeding of Laboratory Animals, Zeist, The Netherlands, and used at an age of 8-9 weeks.

Bacteria

L. monocytagenes L242, serotype $4 \mathrm{~b}$ (klndly provided by Dr. H. van Dijk, Department of Immunology, University of Utrecht, The Netherlands) was used throughout this study. Stock suspenstons of bacteria were prepared as follows: Listerla was grown for 16 h at $37^{\circ} \mathrm{C}$ as described previousily (Antonissen et al., 1981).

Culture bottles were fitted with 0.22 pm filters (Millpore) to release pressure. Bacteria were recovered by centrifugation, washed three times with phosphate buffered saline pH 7.0 (PBS) and stored in swall portions at $-70^{\circ} \mathrm{C}$ in PBS. To determine the $50 \%$ lethal dose $\left(L_{50}\right), 0.5$ mil of serial dilutions of a stock sumpension of bacteria were injected intrapertitoneally (U..p.) into mice. Deaths, which occurred almost exclusively whin 7 days weter infection, were recorded for 14 days. The $\mathrm{LD}_{50}$ was calculated according to Reed and Muench (1938). For batches used In this study $L D_{50}$ values varied between $4.8 \times 10^{5}$ and $2.6 \times 10^{6} \mathrm{CFU}$.

L. monocytogenes serotype 3, streptacoccus pneumoniae serotype 1 (NCTC 8314), and Pseudomonas aeruglnosa serotype 3 (gtraln RIV 76-5321) were kindly provided by Dris. J. 0osterom, D.G. Groothu1s and J. Borst, respectively (National Institute of Public Health, Bilthoven, The Netherlands). L. monocytogenes serotype 3 was cultured as described for L, monocytogenes serotype $4 \mathrm{~b} .5$. pneumoniae was cultured at $37^{\circ} \mathrm{C}$ in brain heart infusion medium 
(Wifico Laboratorles, Detrolt, Mich., U.5.A.) supplemented with $0.2 \%$ sucrose and $1 \% 2.0 \mathrm{M} \mathrm{Na}_{2} \mathrm{HPO}_{4}$ and enumerated on $5 \%$ sheep blood agar plates (Szu et a1., 1983). P. aeruglnosa was cultured as described prevlously (Gonggrijp et al., 1980). For all bacterla mouse passage (Mackaness, 1962) was used to malntain or increase virulence.

\section{Preparation of crude rlbosomes}

L. monocytogenes $\mathrm{L} 242$ was grown at $37^{\circ} \mathrm{C}$ whout aeration in 8 11 ter batches using a Blostat fermentor (B. Braun, Melsungen, $W$. Germany) fltted with a LF32 minlature 11ue filter (Microflow Ltd., Fleet Hants, England) to release pressure Bacteria were harvested by centrifugation when the culture had reached a density of approximately $2.4 \times 10^{9} \mathrm{CFU} / \mathrm{ml}$. The number of bacteria was estimated by reading the turbidity at $540 \mathrm{~mm}$. Bacteria were washed three times with buffer contalning $0.01 \mathrm{M} \mathrm{Tris,} 0.1 \mathrm{M} \mathrm{KCl}, 0.015 \mathrm{M} \mathrm{MgCl}_{2}$, pH 7.2 ( $\mathrm{KM}$ buffer) and used for the preparation of crude ribosomes (Conggrijp et al., 1980). Briefly, bacteria were frozen at $-20^{\circ} \mathrm{C}$ and mechantcally disrupted using a cold thighes pressure cell. The broken cell paste was suspended in $100 \mathrm{ml}$ of $\mathrm{T}$ k buffer. To reduce viscosity the broken cell suspension was treated with $1 \mathrm{mg}$ of DNase (Merck AG, Darmstadt, W. Germany) for 15 min at $37^{\circ} \mathrm{C}$. After DNase-treatment unbroken cells and large cell-envelope fragments were removed by two cycles of centrifugation (20 min $30,000 \mathrm{x} g$ and 20 min $45,000 \times \mathrm{g}$, both at $4^{\circ} \mathrm{C}$ ). The supernatant from the second centrifugation step was flltered through a $0.22 \mathrm{~m}$ filter (Sartorlus-Membranfliter GubH, Gottingen, $\omega$. Germany). The flltrate was centrifuged for $2.5 \mathrm{~h}$ at $180,000 \mathrm{x}$. The resulting pellet containing the ribosomes wa resuspended in Tra buffer to a concentration of $100 \mathrm{mg}$ (wet welght) / ml (crude ribosomal preparation).

Preparation of Eractions I and II

The crude ribosomal preparation was fractionated by molecular sleve chromatography as described previously (Gonggrijp et a1*, 
1980) using a Sepharose $C L-2 B$ (Pharmacla, Uppsala, Sweden) collum $(5 \times 40 \mathrm{~cm})$ equilibrated with $\mathrm{TKM}$ buffer contalning $\mathbb{M} \mathrm{NH}_{4} \mathrm{Cl}$. Two peaks were obtained. Fractions of both peaks were pooled and centrifuged at $180,000 \times g$ for $2.5 \mathrm{~h}$. Pellets were resuspended in TKM buffer to a concentration of $50 \mathrm{mg}$ (wet welght)/mil and 1 yophi1ilzed to determine the dry welght. The dry weight was corrected for the amount of salts added. The lyophilized material was reconstituted with distilled water and diluted th TKM buffer to a concentration of $10 \mathrm{mg}$ (dry welght)/ml.

Fraction II was filtered through a 0.22 im Sartorius filter. In preliminary experiments, filter-sterilization of fraction I was found to cause a loss of protective activity, probably because it contained large amounts of aggregated material. Therefore, fraction I was used without filtration. Unfiltered fraction I was checked for the presence of living Listerla, but none were found. Finally, both fractions were stored at $-70^{\circ} \mathrm{c}$.

\section{Preparation of RNA from fraction II}

RNA was extracted from fraction II with phenol and sodium dodecyl sulphate (SDS) and purified by the method of Poulson (1977).

\section{Chemical analyses}

RNA and protein were determined by the orcinol method of Herbert et al. (1971) and the Lowry method as modified by Hartree (1972), using yeast RNA and bovine serum albumin as the standardis, respectively. Phosphollplas were extracted by the method of Polch et al. (1957) and estimated accordlng to Rouser et al. (1966) using inorganic phosphate as the standard. It was assumed that 1 mg of phosphollpid contained $40 \mathrm{pg}$ of phosphorus.

\section{Polyacrylanide gel electrophores1s}

Polyacrylamide gel electrophoresis of fraction II and purlfled RNA was performed essentially as described by kastelein et al. (1983). After electrophorests the gels were scanned at $260 \mathrm{~nm}$ * Ribosomal RNA of Pseudomonas Eaeruginosa 5321 (serotype 3) 
(Gonggrljp et al., 1981 b) or rlbosomal RNA of Escherichia coll MRE-600 (P.L. Biochemicals GmbH, st. Goar, W. Gernany) was used as a reference.

\section{Ireatment wh Rase and with proteinase $K$}

Before the addition of enzymes, fractions $I$ and II were dialyzed overnight at $4^{\circ} \mathrm{C}$ against $0.005 \mathrm{M} \mathrm{EDrA}$ ( $\mathrm{pH} 7.2$ ) followed by dlalysis against distilled water for $1 \mathrm{~h}$. For RNase treatment, 125 Hz of pancreas-RNase plus 2500 units of RNase Tl (Boehringer Mannhelim, Mannhelm, W. Germany) was added to 1 ml of fraction I or II (contalaing $10 \mathrm{mg}$ dry materlal) and the mixture was incubated for 1 h at $37^{\circ} \mathrm{C}$. Treatment with protelnase $K$ was done similarly, using $250 \mu \mathrm{g}$ of proteinase $\mathrm{K}$ (Sigma Chemical Co., St. Louis, M. O.) per ml of fraction I or II. Controls were incubated without the addition of enzymes.

\section{Protection experiments}

Unless stated otherwise, preparations to be tested were injected 1.p. with or without $300 \mathrm{Hg}$ of the adjuvant dimethyldioctadecylammonium bronide (DDA) (Eastman Kodak Co., Rochester, N.Y.) (Van der Meer et al., 1979; Willers et al., 1979). The total volume injected was $0.2 \mathrm{ml}$ and $\mathrm{PBS}$ was used as a diluent through out. Seven days later mice were challenged $1 . p$. With approximately $10 \times 4 D_{50}$ L. monocytogenes $L 242$, serotype $4 \mathrm{~b}$, suspended in $0.5 \mathrm{ml}$ PBS. The challenge inoculum prepared by direct dilution of a stock suspension of bacteria. The actual number of CFU injected was checked by plating on Trypticase Soy Agar (BBL Microbiology systems, Cockeysville, MD, U.S.A.). Deaths were recorded for 14 days after challenge.

\section{Statistica 1 evaluation}

Significance levels for protection ( $P$ values) were determined by the fisher exact test as described by Bradley (1968). At P values 20.05 differences were considered to be not significant. 
RESULTS

Preparation of fractions I and II

The crude ribosomal preparation was separated into two distinct fractions by molecular sieve chromatography on Sepharose CL-2B. Fraction I was turbid and eluted in the vold volume, whereas fraction II eluted later. Fraction II showed high extinction values at $260 \mathrm{~mm}$, indicating the presence of nuclelc acids.

Chemical composition of fraction I, fraction II and RNA extracted from fraction II

RNA was the major component of fraction II, but almost absent from fraction I (Table 1). The RNA:protein ratio of fraction II was approximately $2: 1$ which is characteristic for purified ribosomes. A relatively large amount of phospholipld was found in fraction $I$, Indicating the presence of cell envelope components (in particular membrane fragments) in this fraction. In four batches tested, the RNA:protein ratio of fractions I and II was found to be reproducible. RNA was extracted from a single batch of fraction II. The purifled preparation contained RNA and protein in a ratio of 100:1. Upon polyacrylamide gel electrophoresis of fraction II two major bands were found. By comparison th reference $r$ RNA from E. coli or $\mathrm{P}$. aeruglnosa, they were tentatively ldentified as $23 \mathrm{~S}$ and $16 \mathrm{~S}$ rRNA (Figure 1). Similar result $\mathrm{B}$ were obtalned with purifled RNA.

Protection induced by fraction I, fraction II, and purified RNA

Both fractions protected mice against a lethal Listerla cha1lenge when combined with DDA (Table 2). Preparations administered without DDA, or DDA alone, did not induce protection. Fractiong I and II were treated with RNase or proteinase $K$ to test the possible involvement of RNA and protein in the induction of protection. As shown in Table 3, protection induced by fraction II was destroyed by RNase-, but not by proteinase K-treatment. Protection 
TABLE I. Chemical composition of fraction I and fraction II

Preparation $\frac{\text { Composition (\% by })}{\text { RAA }^{a} \quad \text { Proteln }^{\text {a }} \text { Phospholipid }}$

$\begin{array}{lllll}\text { Praction } 1 \quad 1 \pm 0.5 & 37 \pm 11 & 16 & 0.03 \pm 0.03 \\ \text { Eraction } 1153 \pm 8 & 29 \pm 5 & 1 & 1.85 \pm 0.12\end{array}$

a Mean of four preparations $\pm S D$.

b Pooled material from three preparations.

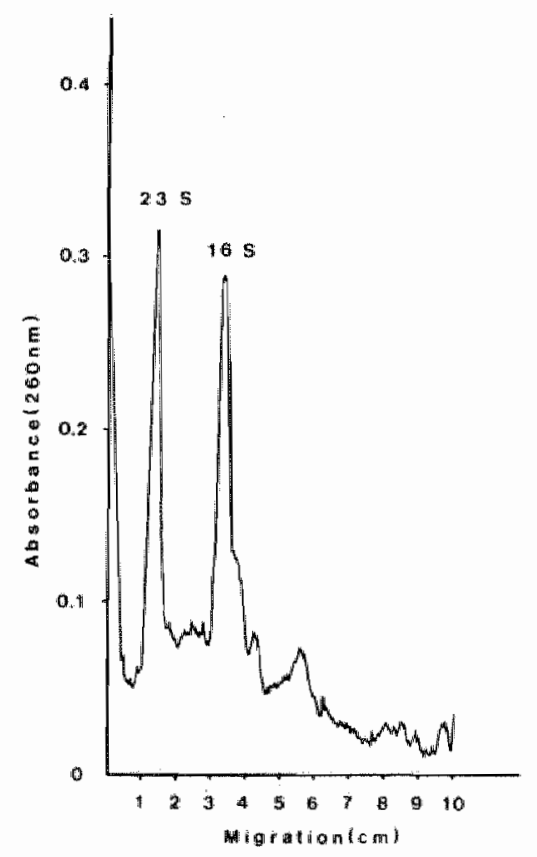

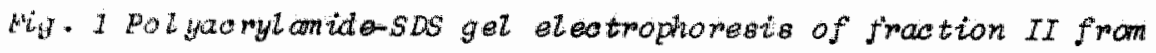
Listeria monoytogenes. 
induced by traction I was not affected by elther treatment. Protection induced by. RNase-treated fraction $I$ m Light have been due to protein components, and protection induced by protelnase $k$-treated fraction I to the small amount of RNA whlch was present in this fraction. However, also sequential treatment of fraction I with RNase and proteinase $\mathbb{K}$ did not reduce its protective propertles. since the results obtained wh four batches of fractions I and II were reproducible, these batches were pooled in all further experiments.

TABLE 2. Protection against L. monocytogenes induced with fraction I and fraction II

\begin{tabular}{lcl}
\hline Preparation & Survival $(\%)^{\mathbf{b}}$ & P valuec \\
\hline Fraction I & $0+0$ & (NS) \\
Fraction I + DDA & $88+16$ & $(<0.001)$ \\
Eraction II & $0+0$ & $($ NS $)$ \\
Fraction II + DDA & $96+8$ & $(<0.001)$ \\
PBS & 0 & - \\
DDA & 0 & (NS)
\end{tabular}

\footnotetext{
a. Fraction I and fraction II were used in a dose of $10 \mu$.

b. Mean of reaut obtained with four oparate preparatione + SD, uaing 6 mice per group; aingle groups were used for PBS and DDA controts.

- I Valwe were calculated with reapect to PBS controlis; NS, not ignifieant.
} 
Because Rase treatient of fraction II destroyed its protective capac1ty, RW was extracted from fraction II and tested in protecclon experiments. As show in Table 4, purified RNA protected mice agalnst lethal Listeria challenge in dose-response relationship. The ability to induce protection against Listeria was not restricted to RNA from the homologous organlsm, because in a similar experinent 2 pg RNA from P. aeruginosa fully protected mice agalnst lethal challenge. RNA from ellther L. monocytogenes or $P$. aeruglnosat only protective in combination with DDA.

Effect of the route of administration on the level of protection induced with fraction $I$, Eraction II, and purtfled RNA

Althougth less effective than 1.p. administration, enhanced reststance was also induced by subcutaneous (s.c.) administration of fraction $I$, fraction II, or RNA in combination th DDA. Intravenous adminlstration did not induce protection (Table 5). Irrespective of the route of administration, all animals treated with PBS or preparations thout DDA died from Llsteria-infection. 
TABLE 3. Effect of treatment with RMase and protelaase $K$ on the induction of protection with fractions $I$ and II

Preparation $^{a} \quad$ Survival $(\%)^{b} \quad \underline{\text { p value }}$

\begin{tabular}{llccc}
\hline Fraction I (control-treated) & + DDA & $100 \pm 0$ & - \\
Fraction I (RNase-treated) & + DDA & $88 \pm 16$ & (NS) \\
Eraction I (proteinase R-treated) & + DDA & $88 \pm 8$ & (NS) \\
Fraction II (control-treated) & + DDA $100 \pm 0$ & - \\
Fraction II (RNase-treated) & $+\mathrm{DDA}$ & $13 \pm 16$ & $(<0.001)$ \\
Fraction II (proteinase K-treated) & $+\mathrm{DDA}$ & $96 \pm 8$ & (NS) \\
DDA & & 0 & - \\
PBS & & 0 & -
\end{tabular}

\footnotetext{
a All preparatione were used in a dose of $10 \mu \mathrm{g}$.

b Mean of results obtained with four separate preparations + $S D$, using 6 mice per group; oingle groups were wed for PBS and DDA controls.

a $E$ values were calculated with mespect to resulta obtained with control-treated materials; NS, not oignificant.
} 
TABLE 4. Protection agaimst L. monocytogenes inducd with pur1fled RWA 1solated from fraction II; dose-response relationship

\begin{tabular}{lcl}
\hline Preparation & Survival $(\%)^{\mathrm{b}}$ & P value $^{\mathrm{c}}$ \\
\hline $10.00 \mathrm{Hg} \mathrm{RNA}+\mathrm{DDA}$ & 100 & $((0.001)$ \\
$3.33 \mu \mathrm{RNA}+\mathrm{DDA}$ & 63 & $(0.01)$ \\
$1.11 \mu \mathrm{RRNA}+\mathrm{DDA}$ & 63 & $(0.01)$ \\
$0.37 \mathrm{HERNA}+\mathrm{DDA}$ & 0 & (NS) \\
$0.12 \mu \mathrm{RNA}+\mathrm{DDA}$ & 0 & (NS) \\
DDA & 0 & -
\end{tabular}

a Group of 8 mice were injected with varying doses of purified RNA with or without DDA and challenged 7 days later. Control received DDA or PBS.

b Alt mice treated with RNA alone or with PBS died from Listeria infection.

c I Values were calculated with respect to DDA controls; NS, not eignifileont.

\section{Time course of protection}

Fraction 1 , fraction II or RNA were administered $1 . p$. In combimation with $\mathrm{DDA}$ at varylng intervals before $1 \cdot \mathrm{p}$. challenge with Listeria. Mice injected with DDA alone served as negative controls. As shown in Figure 2, all preparations induced high levels of protection when the challenge was given 3-7 days after administration, and reststance decreased after 14 days. Furthermore, a relativedy high level of resistance was found one, but not two days after admindstration of RNA in combination with DDA.

\section{Spectelcity of the protection induced with fraction I and RNA}

Mice were injected $1 . p$. With $10 \mathrm{pg}$ of fraction I or RNA in combination with DDA. Controls received DDA alone. Seven days Later mice were challenged 1 *p. with L. monocytogenes serotype 3 , 
P. aeruginosa serotype 3 , or $\mathrm{S}$. pneumoniae serotype 1 . As shown 1 in Table 6, in combination with DDA fraction I as well as RVA protected inice against all three organisus.

TABLE 5. Effect of the route of administration on the level of protection; survival $(\%)$ after intraperftoneal challenge

Preparation $^{a} \quad \frac{\text { Route of administration }}{1 . p .} \quad s+c$.

\begin{tabular}{lrrr}
\hline Fraction I + DDA & 100 & 67 & 0 \\
Fraction II + DDA & 100 & 57 & 7 \\
RNA + DDA & 92 & 58 & 25 \\
DDA & 4 & 4 & 15
\end{tabular}

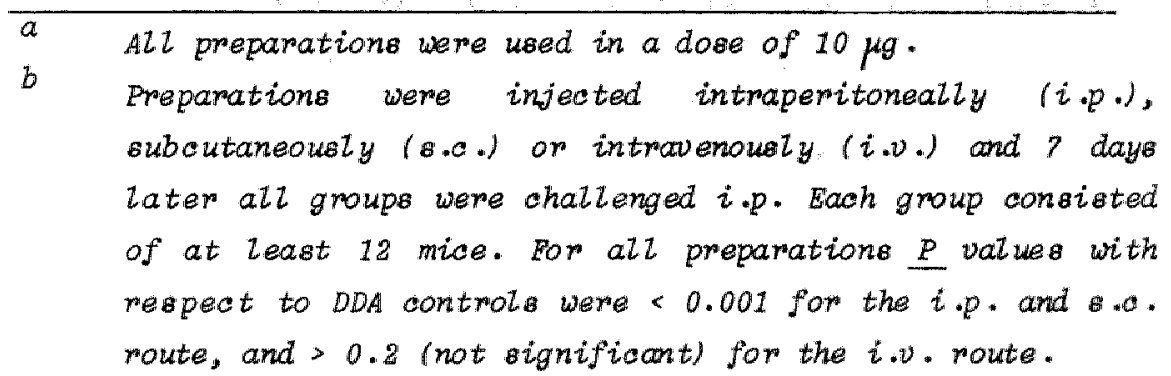




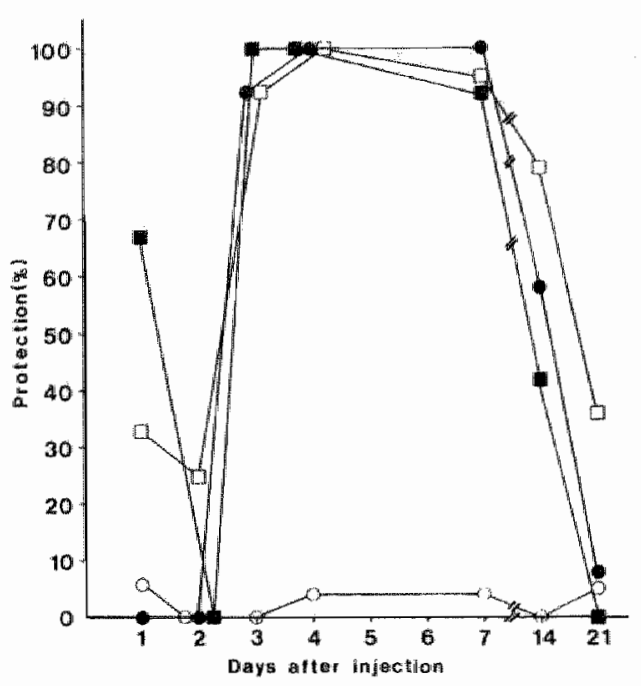

Fig. 2. Time course of protection against L. monocytogenes induced with fraction I, fraction II and RNA. Fraction I, fraction II or RWA were injected i.P. In combination with DDA at varying inter valo bejore $i$. chatienge with Liateria. At least six mice were used for the day 7 pointe; for alt other points at leat twelve mice were uaed. $10: D D A ; 0: 10 \mu g$ frraction $I+D D A ; 0: 10 \mu g$ fraction $I I+D D A ;=10 \mu g R N A+D D A)$.

\section{DISCUSSION}

In this study we have investigated the protective properties of rlbosonal preparations from $L$. monocytogenes. Crude rlbosones were isolated and separated into two fractlons according to a procedure prevlously described for p. aeruginosa (Conggrijp et al., 1980). Chem lcal analysig indicated that fraction I contalned cell envelope components, while fraction II contained the ribosomes (Table 1. Figure 1).

Although chemlcally rather dissimilar, both fractions protected intce agalnst Listerla. As previously shown for other killedLiscerta vaccines (Van der Meer et a1., 1979; Willers et al., 1979), fraction I as well as fraction II had to be given In combination with DDA in order to be protective (Table 2). 
TABLE 6. Specificity of the protection induced with fraction I and RNA from $L$. monocytogenes serotype $4 b$

\begin{tabular}{|c|c|c|c|c|}
\hline \multirow{2}{*}{\multicolumn{2}{|c|}{ Preparation }} & \multicolumn{3}{|c|}{ Survival ()$^{a}$ after challenge with: } \\
\hline & & $\begin{array}{l}\text { Listerla } \\
\text { monocytogenes } \\
\text { Serotype } 3\end{array}$ & $\begin{array}{l}\text { Streptococcus } \\
\text { pneumonlae } \\
\text { Serotype } 1\end{array}$ & $\begin{array}{l}\text { Pseudomonas } \\
\text { aerug loosa } \\
\text { Serotype } 3\end{array}$ \\
\hline $10 \mu \mathrm{g}$ & fraction $I+D D A$ & 95 & 94 & 100 \\
\hline $\mathrm{DDA}$ & & 0 & 22 & 8 \\
\hline $10 \mu \mathrm{g}$ & $\mathrm{RNA}+\mathrm{DDA}$ & 100 & 100 & 83 \\
\hline DDA & & 0 & 25 & 8 \\
\hline $\begin{array}{l}b \\
a \\
d\end{array}$ & $\begin{array}{l}\text { Each group cons } \\
\text { B-valtues with re } \\
\text { Mean challenge d } \\
\text { Mean chaltenge d } \\
\text { Mean chaltenge a }\end{array}$ & $\begin{array}{l}\text { isted of at Zea } \\
\text { spect to oDA con } \\
\text { lobe } 2.8 \times 10^{7} \mathrm{CFU} \\
\text { obe } 3.1 \times 10^{2} \mathrm{CFU} \\
\text { be } 1.5 \times 10^{8} \mathrm{CEU}\end{array}$ & $\begin{array}{l}\text { st twetwe miae. } \\
\text { itrot we we }<0.0 \\
\left(19 x L D_{50}\right) \text {. } \\
\left(26 x L D_{50}\right) \text {. } \\
\left(3 x L D_{50}\right) \text {. }\end{array}$ & In all acoes \\
\hline
\end{tabular}

Experiments with enzymatically treated fractlons suggested that neither RNA nor protein was essential for the Induction of protection with fraction I (Table 3). In addition, the dose of fraction I tested (10 $\mu g$ ) contained approximately $0.1 \mu \mathrm{g}$ RA (Table 1 ), which was found to be insufficlent for the induction of protection Wh purified RNA (Table 4). Therefore, the major protective components of fraction $\mathbb{I}$ renain to be identifled. WNA appeared to be the major protective component of fraction II, because protection induced by this fraction was destroyed by RNase-treatment, and could be reproduced with purtiled RNA (Table 3, 4). Furthermore, even heterologous RNA protected mice agalnst libterlat The presence of RNase senstive protective components in subcellular fractions from Listeria was prevlously shown by willers et al. (1979). Medina et a1. (1975) found that genet1cally resistant (C57 $B L / W J$, but not genetically sensitive $(A / J)$ mice could be protected against Listerla with Llsterla RNA, heterologous RNA, poly 
(1:C) and a number of other substances, without the use of adjuvats. Similar results were reported with respect to the effect of RA on the reslstance of mice towards Salmonella typhimurium (Medina et al., 1975; Misfeldt and Johnson, 1978).

In our sudy $\mathrm{BALB} / \mathrm{c}$ mice, which are genetlcally sensitive to Llsteria (Cheers et a1., 1978), could be protected against a lethal Ligteria challenge with a combination of RNA and DDA, but not w th RA or DDA alone. This may indicate that even genetically aensitive mice can be protected against Listeria with a combination of limunostimulants *

Both DDA (Bloksma et al., 1983; Gordon et al., 1980; willers et a 1., 1979) and polyanions such as RNA (Cohn and Parks, 1967; Fauve, 1971; Madraso and Cheers, 1978; Schultz et a1., 1977; Schultz and chirlgos, 1979) have macrophage-modulating propertes. Therefore, enhanced resistance against Listeria Induced with a combination of RNA and DDA might be due to a synergistic effect of these materlals on macrophage functions.

Enhanced resistance against Lloteria induced with fraction $I$, fraction II or RNA probably contained both systemic and local components, because also s.c. administration protected mice against $i \cdot p$. challenge, although protection was highest after $1 * p$. adminlstration (Table 5).

The higher protection after 1.p. administration may have been due to the use of DDA, which atcracts phagocytic cells to the site of injection (Gordon et a1., 1980).

For all preparations, protection appeared to be relatively shortllved because reststance was already decreased 14 days after admintistration, whereas full or nearly full protection was observed 3-7 days after injection of fraction $\mathbb{I}$, fraction II or RNA. In contrast, Listerla-immunized mice contlmued to show resistance to Listerla at 4 weeks post-immunization (Mackaness, 1964). Protection Induced by RNA was biphasic, because entranced resistance was also observed 1 day, but not 2 days after administration.

Protection induced with RNA as well as fraction I was both serotype- and species-nonspeciflc (Table 6 ).

In this respect our preparations resembled nonspecific inflamma- 
tory stimuli, which were reported to enhance the resistance of mice towards a variety of pathogens, including L. monocytogenes (Fauve, 1981; Fontan and Fauve, 1983; Fontan et a1., 1983).

Therefore the contribution of Inflamation assoclated phenoment to the protective properties of our preparations wlll be subject to further Investigation. With respect to the serotype-nonspecticity of the protection induced with fraction I and RNA, it should be noted that also the enhanced resistance agalnst Listerla induced with living bacterla is serotype nonspeciflc (Wirsing von Koenlg et a1., 1983). Furthermore, increased reslstance agalnst the heterologous organism Brucella abortus was observed unt 1 approximately 2 weeks after primary infection with Listeria monocytogenes (Mackaness, 1964). Apparent1y, the transient nonspecific protection, but not the longer lasting, specific protection induced with living Listerla, could be reproduced with subcellular fractions from Listeria in combination with DDA.

In several respects, the characteristics of the preparations from L. monocytogenes described in this paper were similar to those of the analogous preparations from P. aeruglnosa described prevlously (Gonggrijp et al., 1980, 1981a, 1981 b, 1983). Usting the same purification procedure, crude ribosonal preparations from both organisms could be separated into cell envelope-components (fraction I) and purified ribosomes (fraction II).

Enhanced reslatance agalnst homologous challenge induced with fraction I from elther organism was insenaltive to treatment wth RNase or proteolytlc enzymes. However, in contrat to the preparation from L. monocytogenes, fraction 1 from $P$. aeruginosa induced serotype specific protection without DDA, whlch was probably due to the presence of LPS In this fraction (Conggrijp et al., 1980). Also fraction II from P. aeruginosa was most effect we when given in combination with DDA, and RMA was identifled as 1ts major protective component (Gonggr ljp et al., 1980, 1981b). However, in addition to RNA, LPS appeared to contribute to the protection induced with fraction II from P. eeruginosa, and this contribution was serotype-spectefc (Gonggr1jp et al., 1981a, 1981 b).

Whether components other than RNA contributed to the protection 
Lnduced wth fraction II frow L. monocytogenes remalns to be esablit ahed.

In combination wth DDA, also RMA from P. aeruginosa induced serotype and spectes-nonspectflc protection (Gonggrijp et al., $1981 \mathrm{~b}, 1983)$. Therefore it $1 \mathrm{~s}$ suggested that the mechanisms of enhanced resistance induced with Listerla-RNA and Pseudomonas-RNA are closely related, if not identical.

The authors would like to thank Dr. H. van Dljk, Unlversity of Utrecht, The Netherlanda, for critlcally reading the manuscript.

\section{REFERENCES}

Antonissen, A.C.J.M., van Kessel, K.P.M., van Dijk, H. and W11Lers, J.M.N. 1981. Development of a simple passive haemagglutination-1nhtbition assay for Listeria monocytogenes 11potelchole acid. -J. Immunol. Meth. 44: 351-357.

B.oksma, N., de Reuver, M.J. and WLllers, J.M.N. 1983. Impaired macrophage functions as a possible basis of immunomodification by microblat agents, tilorone and dimethyldioctadecylammonium bromide: -Antonie van Leeuwenhoek 49: 13-22.

Bradley, J.V. 1968. Distribution free statistical tests. -Prentice-Hall, Inc., Hinglewood Cliffs, N.J.

Cheers, C., Mckenzie, L.F.C., Pavlow, H., Waid, C. and York, J. 1978. Restatance and susceptibility of mice to bacterial infection: course of 11steriosis in resistant or susceptible mice. -Infect. Imuan. 19: 763-770.

Cohn, 2.A. and Parks, E. 1967. The regulation of plnocytosis in mouse macrophages. II. Factors linducing vestcle formation. -J. Exp. Med. 125: 213-232.

Cole, P. 1975. Activetion of mouse peritoneal cells to kill Listerla monocytogenes by $T$-1ymphocyte products * -Infect. Immun. 12: $36-41$.

Eisensteln, T.K. 1978. Ribosomal vaccines: a revlew, p. 211-222. In: A. Voller and H. Friedman (eds.), New trends and developments in vaccines. MrP Press LTD, St. Leonard Gate. 
Fauve, R.M. 1971. Influence of synthetic polynucleotldes on the bactericidal power of mouse macrophages against Listerta monocytagenes. In; R.F. Beers Jr. and W. Braun (ed. ), Blological effects of polynucleotides.-Springer Verlag, New York.

Fauve, R.M. 1981. 3. Inflammation revisited: cellular aspects. Inflammation and host resistance against pathogens. Agents and Actions 11: 592-593.

Folch, J., Lees, M. and Sloane Stanley, G.H. 1957. A siuple method for the isolation and purification of total lipides fom amial tissues. -J. Biol. Chem. 226: 497-509.

Fontan, E. and Fauve, R.M. 1983. Inflammation and host resistance to bacterla. III. Increased resistance to Listerla monocytogenes in mice following injection of polyacrylamide microbeads. -Ann. Immuno1. (Pasteur) 134C: 255-264.

Fontan, E., Fauve, R.M., Hevin, B. and Jusforgues, H. 1983. Immunostimulatory mouse granuloma protein. -Proc. Nat1. Acad. Sci. U.S.A. 80: 6395-6398.

Gonggr1JP, R., Mullers, W.J.H.A., Lemmens, P.J.M.R. and van Boven, C.P.A. 1980. Ribonuclease-gensttive ribosomal vaccine of Pseudomonas aerug Inosa. -Infect. Immun. 27: 204-210.

Gonggrijp, R., Volleberg, M.P.W., Lemmens, P.J.M.R. and van Boven, C.P.A. 1981. Evidence for the presence of 1ipopolysaccharide in a ribonuclease-sensitive ribosomal vaccline of Pseudomonas Aerug Inosa. -Infect. Immun. 31: 896-905.

Gongrijp, R., Mullers, W.J.H.A. and vam Boven, C.P.A. 1981 . Serotype-nonspecific protection induced by ribonuclelc acld isolated from the ribosomal vaccine of Pgeudomonas aeruglnosa. -Infect. Immun. 33: 178-185.

Gonggrijp, R., Mullers, W.J.H.A. and van Boven, C.P.A. 1983. Protective activities of ribosonal ribonuclelc acid and 1 ipopolysaccharide of Pseudomonas aeruginosa: comparative sudy. -Antanie van Leeuwenhoek 49: 173-182.

Gordon, W.C., Prager, M.D. and Carrol1, M.C. 1980. The enthancement of humoral and cellular immune responses by dimethyldioctadecylamonium bromide. Cie11. Immunol. 49: 329-340. 
Hartree, E.F. 1972. Determination of proteln: a modification of the lowry wethod that dives a linear photometrlc response. -Anal. Blochem 48: $422-427$.

Herbert, D., Phipps, P.H., and Strange, R.E. 1971. Chemical anaIysts of mlcroblal cells. p. 209-344. In: J.R. Norris and D.W. Ribbons (eds.). Methods in microblology, vol. 5B. Academic Press, Inc., London.

Kastele1n, K.A., Berkhout, B., Overbeek, G.P. and van Duin, J. 1983. Effect of the sequences upstrean from the ribosomebinding site on the yileld of protein from the cloned gene for phage Ms2 coat protein. -Gene 23: 245-254.

Le Garrec, X., Galell1, A. and Aud Lbert, F. 1981, Induction of resistance to Listeria monacytogenes in mice treated with a combination of inactivated bacterla potentiated by trehalose dimycolate. -Ann. Immunol. (Pasteur) 132D: 271-280.

Mackaness, G.B. 1962. Cellular resistance to tnfection. -J. Exp. Med. 116: $381-406$.

Mackaness, G.B. 1964. The immunological basts of acquired cellular reslstance. $-J$. Exp. Med. 120: 105-120.

Madraso, E.D. and Cheers, C. 1978. Polyadenylic acid-polyuridylic acid (poly $A: U$ ) and experimental murine brucellosis. II. Macrophages as target cells of poly A:U in experimental brucellosis. -Immunology 35: 77-84.

Meduna, S., Vas, S.I. and Robson, H.G. 1975., Effect of nonspectic stimulation on the defense mechanisms of Inbred aice. - I. Immunol. 114: 1720-1725.

Misfeldt, M.L. and Johnson, W. 1978. Protective abllity of Salmonella ribosomal protein and RNA in inbred mice. -Infect. Immun. 21: $286-291$.

Peterson, P.K. 1980. Host defense against Pseudomonas aeruglnosa, p. 103-118. In: L. D. Sabath (eds.). Pseudomonas aeruginosa, the organlsm, diseases $1 t$ causes, and thelr treatment. Hans Huber Publishers, Bera, Stuttgart, Vlenna.

Poulson, R. 1977. Isolation, purification and fractionation of RNA, p. 343-344. In P.R. Stewart and D.S. Letham (ed.), The ribonucleic aclds, 2nd ed. -Springer Verlag Inc., New York. 
Reed, L.J. and Muench, H. 1938. A sinple method for estimating Eifty per cent endpoints. -Am. J. Hyg. 27: 493-497.

Rodriguez, G.E., McClatchy, J.K. and Campibe11, P.A. 1974. Induction of resistance by Listeria monocytogenes cell wall fraction. -Infect. Immun. 10: 1163-1169.

Rouser, G., Siakotos, A.N. and Fleuscher, S. 1966. Quantitative analysis of phospholipids by thin-layer chromatography and phosphorus analysis of spots. Lipids $1: 85-86$.

Schultz, R.M., Papamatheak1s, J.D. and Chirigos, M.A. 1977. Interferon: An inducer of macrophage activation by polyanions. - Sclence 197: $674-676$.

Schultz, R.M. and Chirligos, M.A. 1979. Selective neutrallzation by anti-interferon globulin of macrophage actlvation by L-cell interferon, Brucella abortus ether extract, Salmonella typhimurlum 1ipopolysaccharide, and polyanions. -Cel1. Immunol. 48: $5,2-58$

Szu, S.C., Clarke, S. and Robbins, J.B. 1983. Protection agalnst pneumococcal infection in mice conferred by phosphocholinebinding antibodies: specificity of the phosphochollne binding and relation to several types. -Infect. Immun. 39: 993-999.

Van der Meer, C., Hofhuis, F.M.A. and W1llers, J.M.N. 1979. velayed-type hypersensitivity and acquired cellular reslstance in mice immunized with killed Listerla monocytogenes and adjuvants * -Immunology 37; 77-82.

Willers, J.M.N., Bloksma, N., van der Meer, C*, Snlppe, H., van Dijk, H., de Reuver, M.J. and Hofhuls, F.M.A. 1974. Regulation of the immune response by macrophages. -Antonie van Leeuwenhoek 45: $41-48$.

Wirsing von Koenig, C.H., Heymer, B., Hof, H, and FInger, H. 1983. Course of infection and development of immunity in experimental infection of mice with listeria serotypes. -Infect. Immun. 40: $1170-1177$.

World Health Organization Sclentiflc Group. 1973. Cel1 medidat imonity and resistance. WHO Techn. Rep. Ser. 519:6-64 


\section{CHAPTER 4}

DISSOCIA TION BETWEEN ENHANCED RESISTANCE AND DELAYED HYPERSENSTTIVITY INDUCED WITH SUBCELLULAR PREPARATIONS FROM LISTER LA MONOCYTOGENES AND THE ADUUVANT DIMETHYLDTOCTA DEC YLAMMONIUM BROMIDE

SUMMARY

In this study we investigated the relation between enhanced resistance and delayed hypersensitivity (DH) Induced with subcellular preparations from Listeria monocytogenes and the adjuvant dimethyldioctadecylammonium bromide (DDA). Ribosoma1 RNA as well as cell envelope fragments (fraction I) protected mice against lethal Listeria infection. However, only fraction I induced DH against killed Listeria. For the induction of protection with fraction I or RNA as well as for the induction of DH with fraction I, preparations had to be administered in combination with DDA. Fraction I eliclted a DH response In mice Immunized with viable Listeria, but RNA did not. These observations polnted to a dissociation between $\mathrm{DH}$ and enhanced resistance Induced with RNA, and to a dissociation between fraction I and RNA with respect to their ability to induce or eliclt DH. Also DH and enhanced resistance induced with fraction I could be dissociated. Intracutaneous administration of fraction $I$ induced high levels of DH without concomittant induction of protection agalngt lethal challenge with Listeria. On the other hand, intraperitoneal administration of fraction I fully protected mice agalnst lethal infection, but only induced a moderate DH response. DH Induced with fraction I was largely spectflc, whereas enhanced resistance lnduced with this preparation was nonspecific. Finally, protelnase K-sensitive proteins were found to be essentlal for the induction of DH but not far the induction of protection with fraction $I$. 
Previously we described the separation of a crude ribosomal preparation from Listerla monocytogenes serotype 4 b into cell envelope fragments (fraction $I$ ) and purified ribosomes (fraction II) (Antonissen et al., 1985). In combination with the adjuvant DDA, both fractions protected mice against lethal Listeria challenge. Ribosomal RNA was identifled as the major protective component of fraction II, because its protective properties were destroyed by RWase-treatment, and could be reproduced with puriFled RNA extracted from this fraction.

Enhanced resistance induced with fraction $I$ was not affected by RWase-treatment, protelnase $\mathbb{K}$-treatment, or sequential treatment wth both enzymes. Otherwise, the protective propertles of fracthon I were rather similar to thase of fraction II and/or purifled RNA. Subcutaneous as well as intraperitoneal administration of fraction I, fraction II, or purified RNA induced significant protection against intraperitoneal infection, the intraperitoneal route of administration being the most effective. Furthermore, fraction $I$ as well as RNA also protected mice agalnst Streptococcus pneumonlae and Pseudomonas aerug inosa.

In this study we investigated whether fraction I and RNA could be differentlated with respect to their ability to induce or elictt delayed hypersensitivity (DH) agalnst Listeria. As this approach turned out to be succesful, a more extensive characterization of DH Induced with fraction $I$ and RNA was undertaken to a llow comparison of enthanced resistance and DH Induced wh subcellular preparatlons from Listerla monocytogenes.

\section{MATERTALS AND METHODS}

\section{Experimental animals}

Min le BALB/c mice were purchased from TNO, Central Institute for the Breeding of Laboratory Aninals, Zeist, The Netherlands, or from G1. Bomholtgard Ltd., Ry, Denmark, and used at an age of 8-11 weeks. Animals from both suppliers were employed in DH experiments 
but only mice from TNO were used to deternine enhanced resistance against Listerla infection.

\section{Bacteria}

Listerla monocytogenes $L 242$, serotype $4 b$, was kindly provided by H. van Dijk, Department of Immunology, University of Utrecht, The Netherlands and used throughout this study. Listerla was grown whout aeration for $16 \mathrm{~h}$ at $37^{\circ} \mathrm{C}$, using the medium described by Antonissen et al. (1981). Culture bottles were fitted with $0.22 \mu^{\mu i n}$ filters (Millipore) to release pressure. Bacterla were recovered by centrifugation, washed three times with phosphate buffered saline $\mathrm{pH} 7.0$ (PBS) and stored in small portions at $-70^{\circ} \mathrm{C}$ in $\mathrm{PBS}$. Listeria was enumerated by plating on Trypticase Soy Agar (BBL Microbiology Systems, Cockeysville, M.D., U.S.A.).

Streptococcus pneumoniae serotype 1 (NCTC 8314) and Pseudomonas aerug inosa serotype 3 (strain RIV 76-5321) were kindly provided by D.G. Groothuis and J. Borst, respectively (National Institute of Public Health, Bilthoven, The Netherlands).

S. pneumoniae was cultured at $37^{\circ} \mathrm{C}$ in braln heart infusion medium (Difco Laboratorles, Detroit, Mich., U.S.A.) supplemented with $0.2 \%$ sucrase and $0.02 \mathrm{M} \mathrm{Na}_{2} \mathrm{HPO}_{4}$ and enumerated on $5 \%$ sheep blood agar plates (Szu, Clarke and Robbins, 1983).

P. aeruglnosa was cultured and enumerated as described previously (Gonggrijp et al., 1980). For all bacteria mouse passage (Mackaness, 1962) was used to maintain or Increase virulence.

\section{Merobial preparations}

Formalin-killed bacterla. Bacteria were killed by overnight exposure to $1.25 \%$ formalin in PBS. K11led bacterla were washed three tines and stored at $-70^{\circ} \mathrm{C}$ in PBS. Sterility was checked by plating on sultable media.

Subcellular fractions from Llaterta monocytogenes. Subcellular fractions from Liscerla monocytogenes were prepared as described previousily (Antonissen et a1., 1985). Brief1y, Listeria wa grown 1n 8 . 1iter batches at $37^{\circ} \mathrm{C}$ without aeration using a Blostat fermentor (B. Braun, Melsungen, W. Germany) fitted wth a miniature 
Line filter (Mcroflow Ltd., Fleet Hants, England) to release pressure. Cell envelope fragments (fraction I) and purified ribosomes (ftaction II) were obtalned using procedures originally developed for Pseudomonas aeruglnosa (Gonggrijp et al. 1980). However, solubilization with sodium dodecyl sulphate and flltrathon of fraction I was onitted. Ribosomal RWA was extracted from fraction II with phenol and sodium dodecyl sulphate as described by Poulson (1977). Fraction I contalned 37\% proteln, $16 \%$ phosphoILp 1 ds, and $1 \%$ RNA. The purtfled RNA contalned less than $1 \%$ protetin.

Protelnage $K$ treatment of fraction $I$.

Fracton $I$ was treated wh protelnase $K$ as described previousiy (Antonissen et al., 1985): Briefly, Fraction I $(10 \mathrm{mg} / \mathrm{ml}$ in PBS) was dlalysed overnight at $4^{\circ} \mathrm{C}$ against $0.005 \mathrm{M}$ EDTA (pH 7.2) followed by dlalysis against distilled water for $\mathbb{1}$ h. Protelnase K (Stgma Chemical Co., St. Louls, M.O., U.S.A.) was added to a concentration of $250 \mu \mathrm{g} / \mathrm{ml}$ and the mixture was Incubated for 1 or $2 \mathrm{~h}$ at $37^{\circ} \mathrm{C}$. Controls were incubated without the addition of enzyme.

Determination of delayed hypersensitivity and enhanced resistance.

DH responses and enhanced resistance agalnst Listeria were deterintined using modiflcations of techniques deacribed by Van der Meer et al. (1979). For the Induction of DH, preparations were injected intracutaneously (1.c.) with or without $300 \mathrm{pg}$ of the adjuvant DOA (Eastman Kodak Co., Rochester, N.Y., U.S.A.). The cotal volume $1 \mathrm{nj}$ ected wa $0.1 \mathrm{ml}$ per mouse divided over two sites. PBS was used as a diluent throughout.

Seven days after Induction, 20 pl of a suspension of the eliciting antigen was injected 1nto the left hind footpad. DH was measured as the Increase in footpad thickness $24 \mathrm{~h}$ later. Measurements were made using a semt-electrontc footpad-meter (Van D1jk, Versteeg and Hennink, 1976). DH agalnst Llsterla was routinely assessed using $10^{8}$ formalin-killed Listeria as the eliciting antigen.

Increased survival after intraperitoneal (i.p.) injection with 
viable Listerla was taken as a measure of enhanced reststance. The mean lethal dose of the batch of Listeria used was $2.6 \times 10^{6}$ colony forming units for mice obtained from TNO. LD 50 values were determined according to Reed and Muench (1938). Mice were Injected I.P. With approximately $10 \mathrm{LD}_{50}$ of $\mathrm{L}$. monocytogenes suspended in $0.5 \mathrm{ml}$ PBS and the number of survivors was determined 14 days later.

Statistical evaluation.

Signiflcance levels for protection were determined by the Fisher exact test as described by Bradley (1968). Data from DH experiments were analysed using Student's t-test. For both testes differences were considered to be significant at p-values $<0.05$.

\section{$\underline{\text { RESULTS }}$}

Delayed hypersensitivity against fraction I and RNA Induced with living Listeria.

Firstly, we investigated whether fraction I or RNA could elfcit a $\mathrm{DH}$ response in mice immunized i.c. With viable Listeria. As shown in Table 1, living Listerla induced DH against fraction I, but not against the same dose of RNA. Also a tenfold Increase in the dose of RNA used for ellcitation did not produce a DH response.

Induction of DH agalnst Lilsterla with fraction I and RNA

Next, we addressed the question whether DH against Listerla could be induced by Immunization with fraction I or RNA. Preparations were also tested in comblnation with the adjuvant DDA, which was previously shown to be required for the laduction of protection against Listerla th fraction I or RWA (Antonissen et al. (1985). 
TABLE 1. Delayed hypersensitivity agalnst fraction $I$ and RNA Induced by $11 \times 1 \mathrm{ng}$ L. monocytogienes

\begin{tabular}{|c|c|c|c|}
\hline $\begin{array}{l}\text { Lmaunlzation } \\
\text { of alce }\end{array}$ & $\begin{array}{l}\text { Footpad } \\
\text { challenge }\end{array}$ & $\begin{array}{l}\text { Pootpad swelling } \\
(0.1 \mathrm{~mm}) \pm \mathrm{SD}\end{array}$ & $\underline{\mathrm{p}}$ value ${ }^{\mathrm{a}}$ \\
\hline $10^{6} \mathrm{~L}$. monocytogenes & $10 \mu \mathrm{g}$ fraction $\mathrm{I}$ & $5.5 \pm 1.8$ & 0.01 \\
\hline PBS & $10 \mu$ fraction I & $2.7 \pm 0.9$ & \\
\hline
\end{tabular}

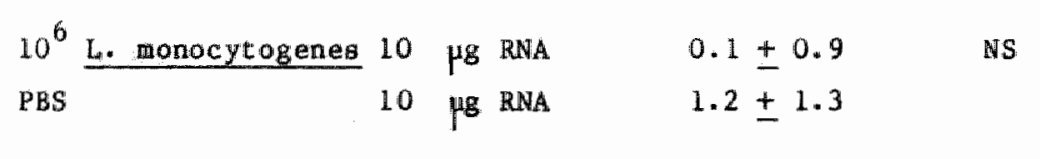

\begin{tabular}{|c|c|c|c|}
\hline $10^{6} \mathrm{~L}$ & monocytogenes & $100 \mu \mathrm{g}$ RMA & $0.9 \pm 1.1$ \\
\hline PBS & & $100 \mathrm{Hg}$ NA & $0.6+0.7$ \\
\hline
\end{tabular}

Groups of 5-6 mice were injected intmacutaneously with $10^{6}$ iving $L$. monooytogenee errotype $4 b$. Seven days later they were challenged in the left footpad with fraction I or RNA. The increase in footpad thickness was determined after $24 \mathrm{~h}$. a values were calculated with respect to FBS controls, using Student' to test. WS: not significant $(\underline{P} \geq 0.05)$. 
TABLE 2. Delayed hypersensitivity against L. monocycogenes induced by immunization with fraction I and RNA

\begin{tabular}{ll}
\hline Immunizing & Footpad swel11ng \\
agent $^{\mathrm{b}}$ & $(0.1 \mathrm{~mm}) \pm$ SD
\end{tabular}

\begin{tabular}{llll}
\hline $10 \mu g$ fraction I + DDA & $7.9 \pm 2.0$ & $<0.001$ \\
$10 \mu g$ RNA + DDA & $1.1 \pm 1.0$ & NS \\
$100 \mu g$ RMA + DDA & $0.8 \pm 0.5$ & NS \\
$10 \mu g$ fraction I & $0.9 \pm 0.8$ & NS \\
$10 \mu$ RMA & $0.3 \pm 0.9$ & NS \\
$100 \mu g$ RMA & $0.2 \pm 0.5$ & NS \\
$10^{6}$ viable Listeria & $13.0 \pm 0.8$ & $<0.001$ \\
PBS & $1.0 \pm 1.0^{\mathrm{c}}$ & - \\
DDA & $1.2 \pm 1.7^{\mathrm{c}}$ & -
\end{tabular}

Groups of 6 mice were injected intracutaneoushy wh preparations to be teeted. Seven days later they were challenged in the Left footpad with $10^{8}$ fomalin-kitzed L. monocytogenes errotype $4 b$. The increase in footpad thiokness was determined $24 \mathrm{~h}$ Zater. Mice immunised with viable Listeria were uaed as positive controls. Mice treated with DDA alone and PBS alone were used as negative controle for groups treated with DDA-adjwated and non-adjuated preparations, "espectively.

b Result represent combined data from 3 experinents and are given as the difference between the means of expermentat groups and negative controta. Standard deviatione were catcutated by equare addition of SD values of experimental groups and cantrols (Moroney, 1968).

- Absolute value calculated wsing combined data fmom 3 expemimente.

d $P$ valwes were calculated woing student' t-test. NS: not gignifiacont $(\underline{P} \geq 0.05)$. 
Praction I laduced DH agalnst kllled Listerla, but only in comblnation wth DDA (Table 2). RNA, efther wth or without DDA, did not Induce DH. Also a tenfold higher dose of RNA (100 pg) was found to be ineffective.

Effect of the route of administration on the lnduction of $D H$ and enhanced resistance 1 th fraction $I$ and RWA.

In contrast to 1.c. administration, $1 . p$. Injection of fraction I only induced a moderate DH response against killed Listeria (F1g. 1). RNA did not Induce DH via elther route. As 1.p. administration of fraction I or RNA was previously found to be quite effective for the induction of protection agalnst lethal infection (Antonissen et al ", 1985) it was decided to challenge all groups with vlable Listerla after determination of the DH response. Only mice which had recelved fraction I or RNA wia the $1 . p$. route were found to be protected against $1 . p$. challenge with viable Listeria (FIg. 1).

Speciflcity of DH Induced with fraction I.

Formalin-killed Streptococcus pneumonlae and Pseudomonas aeruginosa were wsed to determine the specificty of DH induced with fraction I.

As shown in table 3, fraction I also laduced a low but slignifcant DH-response towards $S$. pneumonlae and $\mathrm{P}$. aeruglnosa. Using two way vartance analysis (kindly performed by A. Volovics, Department of Medical Informatics and Statistics) the DH response towards Listeria was found to be significantly higher $(\mathrm{P}=0.017)$ than the response towards S. pneumonlae and P. aleruglnosa. 


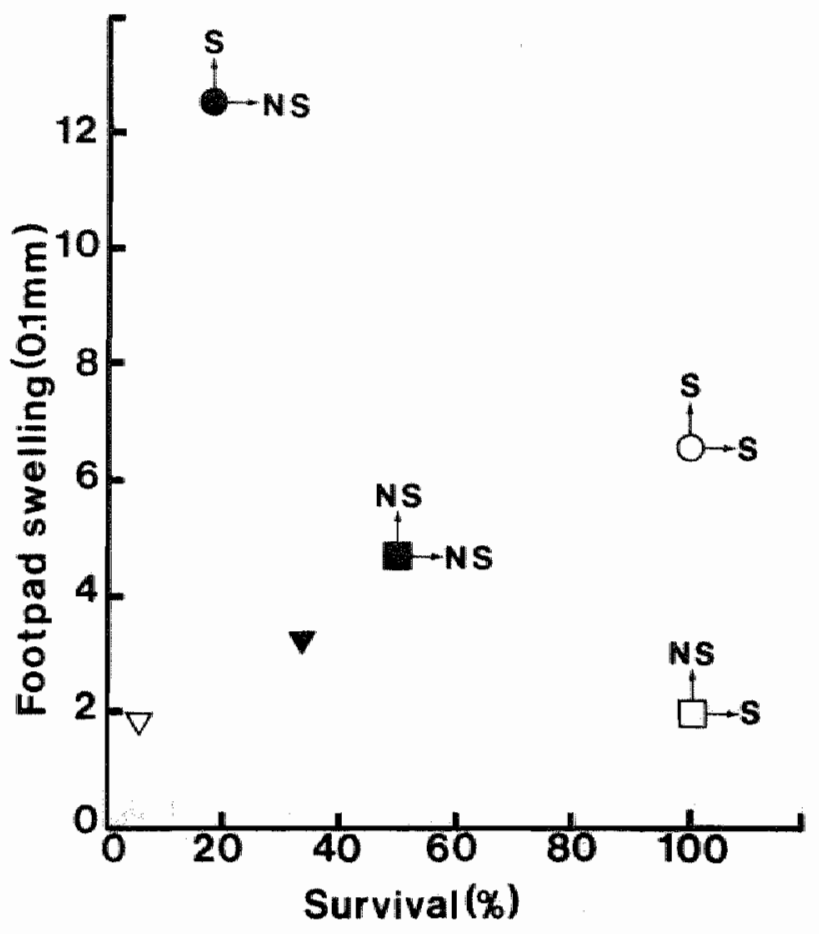

Fig. 1. Effect of the route of adminiatration on the induction of DH and proteation against Listeria with fraction I and RNA. Groups of 6 mice were injected intraperitoneally (open abmols) or intracutaneousty (closed symbata) with $10 \mu g$ of fraction I (c,o) or 10 Hg of RNA (1, a). Before injeation both preparatione were combined

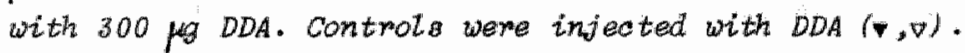

After seven days on was elicited by footpad challenge wh th $10^{8}$ fomalin-kilzed Liateria and rad as the inorase in footpad thicbrese $24 \mathrm{~h}$ tater. After detemination of the DH responee all groups were challenged intmaperitonealizy with $10 \mathrm{LD}$ 50 Listeria monocytogenes. The percentage of survivore was detemined 14 dayo Later. significance (S) or instgnificance (WS) of protiection and $D H$ is indicated by horisontal ( $\rightarrow$ ) and vertical ( 1 ) arrows, respectively. P value were calculated with reopect to DDAcontrols. 
Effect of enzymatic creatment on the lnduction of DH with fracton I.

As shown in Table 4, treatment th proteinase destroyed the abllity of fraction I to Induce DH against Llsteria, suggesting that DH was primar11y directed against protein components of this fraction.

\section{DISCUSSION}

Results described in this paper clearly point to a dissociation between enhanced reststance and $\mathrm{DH}$ induced with subcellular fractions from L1sterfa and the adjuvant DDA. RNA induced enhanced

TABLE 3. Spectficity of delayed hypersensitivity induced whth Eraction I

\begin{tabular}{lll}
\hline $\begin{array}{l}\text { Immunization } \\
\text { of mice }\end{array}$ & $\begin{array}{l}\text { Footpad } \\
\text { challenge }\end{array}$ & $\begin{array}{l}\text { Footpad swelling } \\
(0.1 \text { palue }\end{array}$ \\
& & SD)
\end{tabular}

$\begin{array}{llll}10 \mu \mathrm{gI}+\mathrm{DDA} & \text { L. monocytogenes } & 7.8 \pm 2.5 & <0.001 \\ \text { DDA } & \text { L. monocytogenes } & 1.9 \pm 0.5 & -\end{array}$
$10 \mu \mathrm{gFI}+\mathrm{DDA}$
S. pneumontae
$4.7 \pm 1.0$
0.01
DDA
S. preumoniae
$2.5 \pm 1.6$

$10 \mathrm{WBT}+\mathrm{DDA}$

P. aeruginose

$5.9 \pm 2.4$

0.02

DDA

P. aeruglnose

$3.6+1.2$

Groups of $6-7$ mice were injected introwntaneously with $10 \mathrm{~kg}$ fraction I (FI) + DDA or with DDA alone. Seven days later they were challenged in the left footpad with $10^{8}$ formal in killed $L$. monocytogenes serotype $4 b_{s} S$. pnewnoniae or $P$. aeruginosa. The inereace in footpad thiokneas was detemined ajter $24 h$.

b Values were calculated with respect to DDA controls. 
TABLE 4. Effect of protelnase K-treatment on the Induction of delayed hypersensitivity with fraction I

\begin{tabular}{lll}
$\begin{array}{l}\text { Treatment of } \\
\text { fraction I }\end{array}$ & $\begin{array}{l}\text { Footpad swelling } \\
(0.1 \mathrm{~mm} \pm \mathrm{SD})\end{array}$ & P value \\
\hline none & $7.8 \pm 2.5$ & $<0.001$ \\
$37^{\circ} \mathrm{C}, 2 \mathrm{~h}$ & $8.8 \pm 2.4$ & $<0.001$ \\
proteinase $\mathrm{K}, 37^{\circ} \mathrm{C}, 1 \mathrm{~h}$ & $2.5 \pm 0.7$ & $\mathrm{NS}$ \\
proteinase $\mathrm{K}, 37^{\circ} \mathrm{C}, 2 \mathrm{~h}$ & $2.4 \pm 1.2$ & $\mathrm{NS}$ \\
mo fraction I & $1.9 \pm 0.5$ & - \\
(DDA contro $\mathrm{I})$ & &
\end{tabular}

a Fraction $I$ was treated with proteinase $K$ for 1 or $2 h$ at $37^{\circ} \mathrm{C}$. Untreated froction $I$ and fraction I ineubated for $2 \mathrm{~h}$ without the addition of enazme were used as controls. After appropiate dilution and combination with DDA, preparations were injected $i . c$. in a dose equivalent to $10 \mathrm{pg}$ untreated fraction $I$, using 6-7 mice per group. Control s received DDA alone. Seven days later DH was elicited by footpad challenge with $10^{8}$ formalin-killed Listeria. The incmease in footpad thickness 24 h after elicitation was used as a measure of $D H$.

b $\quad$ p values were calculated with respet to DDA controls.

NS: Not significant $(\underline{P} \geq 0.05)$.

resistance against lethal Listerda-challenge (Fig. 1) but it did not Induce or elicit DH (Table 1,2; F 18. 1). In contrast, a blghly - Igniflcant DH response was induced by Immunization of mice with viable Llsteria (Table 2). DH as we11 as protection agalnat Listeria induced by Immunization with viable bacteria are mediated by T-cells (Kaufmann, Simon and Hahn, 1979), but the relation between both phenomena of cell-mediated immunity is controversial. According to Kaufmann and Hahn (1982) both $\mathrm{DH}$ and enhanced resistance against Listeria could be transferred to normal reciplent 
wile with the same clone of Listerla-speciflc T-cells. On the other hand, Chen-Woan, Sajewsil and McGregor (1985) showed that T-cells from rata tmounlized with viable Listeria could be separated Lnto mutually exclusive subsets of T-cells wediating DH and T-cells medlating protection agalnst Listeria. However, T-cells mediatlng DH were not completely irrelevant for the expression of protection, as a combination of T-cells mediating DH and T-cells medlating protection conferred a higher level of resistance than the protective subset allone (Chen-Woan et al, 1985). As RNA did not Induce $\mathrm{DH}, \mathrm{T}-\mathrm{cell}$ s mediating $\mathrm{DH}$ probably did not contribute to the expression of protection Induced with RNA. Protection agalnst Listerla induced wth Listerla RNA wight in fact be entirely due to non-Imunologlcal mechan1sms because also heterologous ribosomal RNA (Antonissen et a1., 1985) and poly(A). Poly(U) (Antonissen et al., manuscript in preparation) protected mice against Listerta Infection. Furthermore, cyclosporin $A$, which inhtbits the induction of $\mathrm{T}$-cell dependent protection with viable Listeria (Schaffner, Douglas and Dav1s, 1983) did not affect the Induction of enhanced in vivo kll1ing of Listeria with RNA (van den Bosch et a1., manuscrlpt in preparation). Concelvably, RNA directly activates macrophages as suggested by Madraso and Cheers (1978) with respect to the mechanism of protection against Brucella abortus induced with poly (A). poly (U).

Al so ribosomal RNA from Mycobactertum tuberculasls induced protection agalnst homologous challenge whout Induction of DH (Youmans and Youmans, $1969, a$, b). However, protection against $M$. tuberculosis induced with mycobacterial RNA was attrlbuted to 1 ymphocytemedlated macrophage activation (Patterson and Youmans, 1970), and therefore might be closely related to the $T$-cel1-dependent immunty induced with viable mycobacteria (North, 1974). Both DH and enhanced resistance against Listerla could be Induced with fraction I, and this fraction also ellcited DH in mice immunized with viable Lleterla (F1g* 1; Table 1,2). However, DH was highest when fraction I was administered $1 . C$. , whereas $1 . p$. Injection was required for the induction of enthanced resistance against $\mathbf{i} \cdot \mathbf{p}$. challenge (FIg. 1). Similar results with respect to the effect of 
the route of administration were reported by Van der Meer et al. (1979), who studled the induction of DA and enhanced resistance with unfractionated killed Listerla and DDA.

The relative ineffectiveness of the $1 . p$. route of administration for the induction of DH may have been due to restricted recirculation from the peritoneal cavity of Listeria speciflc T-cells which tend to accumulate in Inflamatory foci (North and Spitalny, 1974). In this respect it should be noted that DDA causes a relatively mild inflammatory reaction leading to accumulation of predominantly macrophages/monocytes at the site of injection (Gordon, Prager and Carro11, 1980). Thus, 1.p. adminletration of fraction I plus DDA might be more effective for the induction of protection against $1 \cdot p$. challenge than 1 .c. administration because in the former case Listeria specific $\mathrm{T}$-cells and lncreased numbers of effector macrophages/monocytes are already present at the site of infection at the time of challenge.

On the other hand, 1 imited space might restrict the intracutaneous accumulation of Listeria-specific $T$-cells and thus explatn the relative effectiveness of $1 . c$. administration for the induction of DH .

Previously we showed that also subcutaneous lmmunization with fraction I plus DDA protected mice agalnst $1 . p$. challenge with Listerla (Antonissen et al, 1985). Therefore the absence of protection agalnst 1.p. challenge after 1.c. Immundzation was probab$1 y$ not exclusively due to the distance between the fite of lminum zation and the site of challenge. Concelvably, 1.c. Inmunization Induces the proliferation of $\mathrm{I}$-cells medlating $\mathrm{DH}_{\text {, }}$ but not of T-cells mediting cellular resistance.

Attempts to induce $\mathrm{DH}$ againgt Listerla by wubcutaneous immunization with fraction I plus DDA produced eratic results (data not shown).

Enhanced resistance induced with fraction I was nonspectfic, as fraction I also protected mice against S. pneumoniae and $P$. aeruginosa (Antonissen et al, 1985). DH responses against $\mathbf{s}$. pneumoniae and $P$. aeruginosa induced with fraction $I$ were by themselves sigmificant (Table 3 ), but at the same time signifi- 
cantly lower than the DH response agalnst Listeria. Therefore DH Induced 1 th fraction $I$ appeared to be largely but not completely specticic.

Protelnase-k senstive proteins were identifled as the components of fraction I which Induced DH against Listerla (Table 4). However, the protective components of fraction I were proteinase K-resistant (Antonlssen et al, 1985), indicating that protection liduced with fraction I was due to non-protein components or to protelnase K-reslstant peptides. Therefore DH and protection against Listerla Induced with fraction I not only had different characteristics, but were also due to chenlcally different components of this fraction.

Dur observations corroborate several other studies in which a disociation between enhanced resistance and DH against Listeria was observed (Barry and Hinrichs, 1983; Kerckhaert, Hofhuis and W11lers, 1977; Osebold, Pearson and Med1n, 1974). In addition we identified the chemical nature of the DH-inducing components of fraction I. Consequently this preparation might be a suitable source for the purffication of DH-inducing components from Llsterla monocytogenes.

\section{REFERENCES}

Antonissen, A.C.J.M., Lemmens, P.J.M.R., Gonggrijp, R., van den Bosch, J.F. and van Boven, C.P.A. 1985. RNase-sensltive and RNase-insenstelve protective components isolated from Listeria monocytogenes - Antonte van Leeuwenhoek 51: $227-240$.

Antonissen, A.C.J.M., van Kessel, K.P.M., van D1jk, H. and W11.ters, J.M.M. 1981. Development of a simple passive thaemaglutination-inhibition assay for Listerla monocytogenes 11potelicholc acid - J. Immunol. Meth. 44: $351-357$. 
Barry, R.A. and Hinrlchs, D.J. 1983 Lack of correlative enhancement of passive transfer of delayed- hypersensitivity and antilisterial resistance whem using concanavalin $A$ stimulated primed spleen cells - Infect. Immun. 39: 1208-1213.

Bradley, J.V. 1968. Distribution free statistical tests, p. 195-203. Prentice-Ha11 Inc., Englewood cliffs, New Jersey "

Chen-Hoan, M., Sajewski, D.H., and McGregor, D.D. 1985. T-cell co-operation in the mediation of acquired reslstance to Listeria monocytogenes - Immunology 56: 33-42.

Gonggrijp, R., Mullers, W.J.H.A., Lemmens, P.J.M.R. and van Boven; C.P.A. 1980. Ribonuclease-sensitive ribosomal vacclne of Pseudomonas aeruginosa - Infect. Inmun. 27: 204-210.

Gordon, W.C., Prager, N.D. and Carro11, M.C. 1980. The enhancenent of humoral and cellular $\mathbb{1}$ mmune responses by dimethyldioctadecylammontum bromide - Ce11. Immunal. 49: 329-340.

Kaufmann, S.H.E. and Hahn, H. 1982. Blologlcal functions of T cell lines with speciflcity for the intraceliular bacterium Listerla monocytogenes in vitro and in vivo - J. Exp. Med. 155: $1754-1764$.

Kaufman, S.H.E., Simon, M.M., and Hahn, H. 1979. Specific Lyt 123 cells are involved in protection against Listerla monocytogenes and in delayed-type hypersensitivity to listerial antigens - J. Exp. Med. 150: 1033-1038.

Kerckhaert, J.A.M., Hofhuls, F.M.A. and W11lers, J.M.N. 1977. Influence of cyclophosphamide on delayed hyperaenditivity and acquired cellular resistance to Listeria monocytagenes In the mouse - Immunology 32: 1027-1032.

Mackaness, G.B. 1962. Cellular resLtance to infection - J. Exp. Med. 116: $381-406$.

Madraso, E.D., and Cheers, C. 1978. Polyadenylic acid - polyuridylic acid (poly $A: U$ ) and experimental murine brucellosis II. Macrophages as target cells of poly A:U in experimental brucellosis - Imimunology 35: 77-84.

Moroney, M.J. 1968. Facts from flgures - Penquin Books Lid. Harmondsworth, Muddlesex, England. 
North, R.J. 1974. T-cell dependence of macrophage activation and mobllization during infection with Mycobacterlum tubercuLos1s - Infect. Irmun. 10:66-71.

North, R.J. and SpitaIny, G. 1974. Inflammatory Iymphocyte in cell-medlated antibacterlal lmunlty: Factors governing the accurulation of mediator $\mathrm{T}-\mathrm{ce} 11 \mathrm{~s}$ in peritoneal exudates Infect. Immun. 10: 489-498.

Osebold, J.W., Pearson, L.D. and Medin, F.N.I. 1974. Relationship of antinlcroblal cellular immuntey to delayed hypersenstivity In 1lsteriosis - Infect. Immun. 9: 354-362.

Patterson, R.J., and Youmans, G.P. 1970. Demonstration in tissue culture of lymphocyte-medlated immuntty to tuberculosis Infect. Immun. 1: 600-603.

Poulson, R. 1977. The ribonuclelc acids, 2nd edn, p. 343-344. Springer Verlag Inc.", New York.

Reed, L.J. and Muench, H. 1938. A simple method for estimating fifty per cent endpoints. Am. J. Hyg. 27: 493-497.

Schaffner, A., Douglas, H. and Davis, C.E. 1983. Models of T-cell deflctency in 11sterlosis: The effect of cortisone and cyclosporin A on mormal and nude BALB/C milce - J. Immunol. 131: $450-453$.

Szu, S.C., Clarke, S. and Robblins, J.B. 1983 Protection against pneunococcal Infection in mice conferred by phosphocholinebinding antibodies: speclficity of the phosphocholine bindug and relation to several types - Infect. Immun. 39: 993-999.

Van der Meer, C., Hofhuls, F.M.A. and Wlllers, J.M.N. 1979. Delayed-type hypersensitivity and acquired cellular resistance In mice immunized with killed Listerla monocytogenes and adjuvant - Immunology 37: 77-82.

Van Dijk, H., Versteeg, H. and Henaink, H.J. 1976. A sem1electronic device for measuring delayed hypersensitivity in the mouse by footpad swelling - J. Immunol. Meth. 12: $261-265$. 
Youmans, G.P. and Youmans, A.S. 1969a. Allergenlelty of mycobacterial ribosomal and ribonucleic actd preparations in mice and quinea pigs - J. Bacter101. 97: 134-139.

Youmans, A.S. and Youmans G.P. 1969b. Factors affecting Immunogenic activity of mycobacterial ribosonal and ribonuclelc acid preparations - J. Bacteriol. 99: 42-50. 


\section{CHAPTER 5}

\section{PURIEICATION OF A DELAYED HYPERSENSITIVITY-INDUCING PROTEIN FROM LISTERIA MOHOCYTOGENES}

SUMMARY

Ce11-envelope fragments were prepared from Listeria monocytogenes L242, serotype 4b: Delayed hypersensitivity (DH) Inducing proteins were extracted with deoxycholate and separated into two fractions by filtration through a Sephacryl $\mathrm{S}-200$ column equidibrated wh deoxycholate buffer. The second peak eluting from the Sephacryl column was fractionated usting ion exchange chromatography on a DEAE Sepharose CL-6B column in the presence of $6 \mathrm{M}$ urea. A purified $20,400 \mathrm{MW}$ protein which induced DH against Listeria was obtalned by lsocratic elution. Three other DH inducing fractions containing several protein bands were eluted by a gradient of potassium thlocyanate (KSCN) In urea buffer. Our results indicate that denaturing conditions can be employed for the fractionation and purification of DH inducing proteins from Listeria monocytogenes. In addition 1 t 18 suggested that the procedure described wight also be useful for the purtflcation of other antigens involved in cellular lmine reactlons.

\section{INTRODUCTION}

Previously we described the separation of a crude ribosomal. preparation from Listeria monocytogenes into cel1-invelope fragments (fraction I) and purifled $r$ Hbosomes (fraction II). In comblmation with the adjuvant dimethyldioctadecylammonfur bromide (DDA) both fractions protected mice against lethal Listeria infection. RNA was identifled as the major protective component of fraction II, because 1 ts protective propertles were degtroyed by 
RNase-treatment and could be reproduced with purifled RNA. Enhanced resistance induced by fraction I was not affected by either RNase- or protelnase K-treatment. In combination with DDA, fractlon I as wil as RA also protected mice against heterologous challenge, suggesting that protection induced with these preparations was primarily due to a nonspecific stimulation of host resiatance (1).

Jiction I plus DDA induced delayed hypersensitivity (DH) against K1Lled Liseria, and DH could also be eliclted with fraction I In mice lnminized with viable Listerla. DH could not be induced or ellclted wth R.NA. In contrast to enhanced resistance, DH induced wth fraction $I$ appeared to be largely specific. Furthermore, protelnase $K$-treatment destroyed the ability of fraction $I$ to Lnduce DH against Listerla (Antonisisen et al., submitced for publication). Therefore, DH induced with fraction I was apparently due to protein components present in this fraction. With this observation the purification of DH-inducing components from Listeria monocytogenes has become feasible. Experiments aimed at such a purification are the subject of this paper.

\section{MATERIALS AND METHODS}

Experimental animals

Male BALB/c mice we re obtalned from TNO, Central Institute for the Breeding of Laboratory Antmals, Lelst, The Netherlands, and used at an age of $8-11$ weeks.

\section{Determination of delayed hypersensitivity}

DH agalnst Listeria was detemined as described previously (Antonissen et al., submitted for publication) using modifications of published procedures (2).

In brief, mice were injected intracutaneously (1.c.) with preparations to be tested, suspended in phosphate buffered saline, $\mathrm{pH} 7.0$ $(\mathrm{PBS})$. Before injection materlals were combined with $300 \mathrm{pg}$ of the adjuwant DDA (Eastman Kodak CO., Rochester, N.Y., U.S.A.). Controls receiwed DDA alone. After seven days DH was ellcited by 
injection of $10^{8}$ formalin-killed Listeria into the left footpad and measured as the increase 1 in footpad thickness 24 h later. Measurements were made using a semt-electronic footpad-meter (3). Results were analysed statistically using Student's t-test. Footpad swelling was considered to be significant at p-values $<0.05$ relative to DDA controls.

Preparation of fraction 1

Cell-envelope fragments (fraction I) were prepared from Listeria monocytogenes L242, serotype $4 \mathrm{~b}$, as previously described (1). Fraction I contalned $37 \%$ protein, $16 \%$ phospholiplds, and $1 \%$ RNA (1). Preliminary experiments indicated that DH Inducing proteins could be extracted from fraction I with deoxycholate (4) or wth $6 \mathrm{M}$ urea. Therefore, it was decided to atcempt purification of DH inducing protelins by gel filtration in the presence of deoxycholate and lion exchange chromatography in 6 urea.

\section{Extraction with deoxycholate}

Fraction I (100 mg; $5 \mathrm{mg} / \mathrm{ml}$ in PBS) was dialysed overnight against $10 \mathrm{mM}$ Tris-HCl, pH 7.5, containing $0.5 \%$ sodlut deoxycholate and $1 \mathrm{mM}$ 2-mercaptoethanol (DOC-buffer). Insoluble material was removed by centrifugation ( $30 \mathrm{~min} 31,000 \mathrm{xg}$ ), washed once with DOC-buffer, dialysed agalnst PBS for 2 days and stored at $-70^{\circ} \mathrm{C}$ (DOC-sediment). The supermatant from the first centrifugation step (DOC-supernatant) was used for further fractionation.

\section{Gel H1tration}

The DoC-supernatant fraction was supplemented with 100 mo 2-mercaptoethanol, heated for $30 \mathrm{~min}$ at $37^{\circ} \mathrm{C}$, cooled to $4^{\circ} \mathrm{C}$ and applied to a $90 \times 2.6 \mathrm{~cm}$ column of Sephacryl $\mathrm{S}-200$ (Pharmacla $\mathbb{P}-\mathrm{L}$ Blochemicals, Uppsala, Sweden), equilibrated with Doc-buffer. The eluate was scanned at $280 \mathrm{~nm}$ and collected 1 in fractions of $2.3 \mathrm{ml}$. Peaks were pooled, concentrated and tranaferred to PBS. 


\section{Concentration and buffer exchange}

In general, a $50 \mathrm{ml}$ Anicon concentration cell fitted with a MLLLpore PTGC metbrane was used for concentration and buffer exchange. Buffer exchange was achleved by several steps of concentration and dilution wh the buffer to which the sample had to be transferred. Fractions contalatng deoxycholate were dialysed for 24-48 h against $10 \mathrm{mM} \mathrm{Trig}-\mathrm{HCl}$, pH 7.5 (Tris-buffer) to remove most of the deoxycholate. Residual deoxycholate was removed by several steps of concentration and dilution with Tris-buffer, using the Amicon concentration cell. The removal of deoxycholate was monitored by mixing a drop of concentrate with $1 \mathrm{M} \mathrm{MgCl}_{2}$ " which precipttates deoxycholate. Subsequentiy fractions were transferced to PBS, us Ing the concentration/dilution procedure already described.

\section{Ion exchange chromatography}

One of the fractions obtained by gel filtration was selected For further purtfication using ion exchange chromatography in the presence of $6 \mathrm{M}$ urea (Blo-Rad electrophoresis quality). DEAE-Sepharose CL-6B (Pharmacia P-L Biachemicals, Uppsala, Sweden) was equilibrated three times with $0.5 \mathrm{M} \operatorname{Tris}-\mathrm{HC1}$, pH 7.5). Subsequently it was treated with three cycles of end buffer ( 6 M urea, $1 \mathrm{M} \mathrm{KSCN}, 1 \mathrm{mM}$ 2-mercaptoethanol, $50 \mathrm{mM} \operatorname{Tr} 1 \mathrm{~s}-\mathrm{HCl}, \mathrm{pH} 7.5$ ) and starting buffer $6 \mathrm{M}$ urea, $1 \mathrm{mM} 2$-xercaptoethanol, 50 miM Tris-HCI, pH 7.5. A $15 \% 1.6 \mathrm{~cm}$ column was prepared from precycled lon exchanger and equilibrated whth starting buffer. The material to be separated was treated with $100 \mathrm{mM} 2$-mercaptoethanol (30 min, $37^{\circ} \mathrm{C}$ ) and transferred to starting buffer.

After removal of insolubles by centrifugation (30 in. $31,000 x$ g), the material was aplied to the column. After two column volumes of starting buffer, the column was developed with a linear gradient (2 $\times 150$ iil) of $0-1$ M KSCN In starting buffer. The eluate was scanned at $280 \mathrm{~nm}$ and fractlons of $0.9 \mathrm{ml}$ were collected. Pooled fractions were concentrated and transferred to PBS. 


\section{Chenical analyses}

proteln was determined by the Lowry method as modifled by Hartree (5) using bovlne serum albumin as the standard. Fractions were analysed qualitatively on $11 \%$ polyacrylanide gels in the presence of sodium dodecyl sulphate (SDS-PAGE) (6). The Pharmacia low molecular weight electrophoresis callbration kit (Phartacla Flne Chemicals $A B$, Uppsala, Sweden) was used for molecular welght estimation.

\section{RESULTS}

\section{Extraction with deoxycholate}

Approximately $50 \%$ of the protein present in fraction $I$ was solubilised by extraction whth deoxycholate. The extraction procedure appeared to be partially selective, although both the extract and the sediment left after extraction contalned a large number of different proteins (Fig. 1).

\section{Gel filtration}

Two peaks (S1 and S2) were obtalned upon gel filtration of a deoxycholate extract of fraction I (Fig 2 ). In comblnation with DDA, both fractions induced DH agalnst Listeria (Table 1). As fraction $\mathrm{S} 2$ appeared to be less complex than fraction $\mathrm{S} 1$, the former was selected for further purification. This was done using pooled material from two batches, which were essentially ldentical as assessed by SDS-PAGE (not shown). 


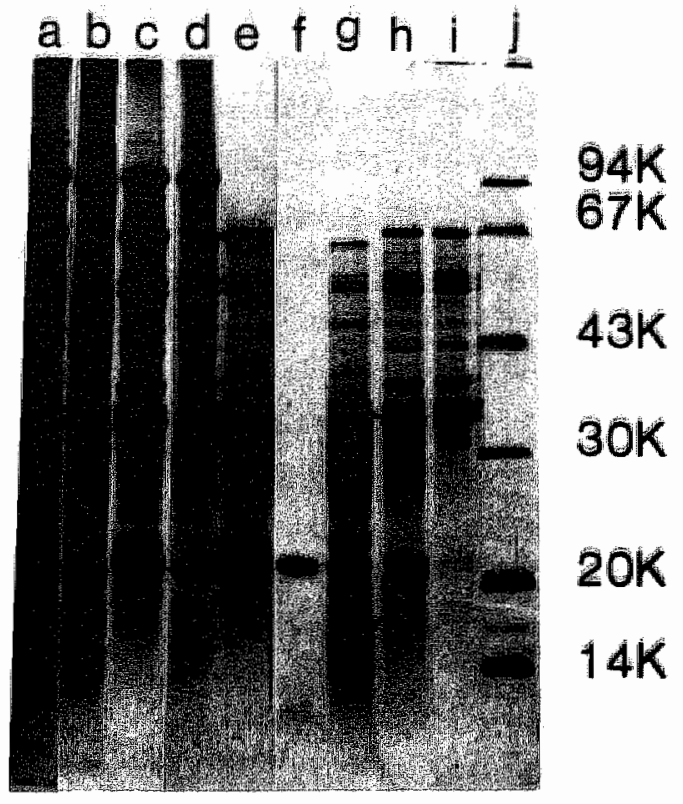

Fig. 1. SDS-PAGE anatysio of cell-envelope fragmente (fraction $I$ ) isolated from Listeria monocytogenes and fractions obtainad by deoxychotate extraction, gel fittration and ion exchange chromatography. (a: fmaction 1 ; b: DOC-sedtment; $d:$ DOC-aupematant; $d$, e: Sephaoryl fraction s1, sa; $f, \theta, h, i ; D E A E$ fractions $D 1, D 2, D 3$, D4; I: Phamaota low moleoular wetght electrophoresi calibration Kitis. 


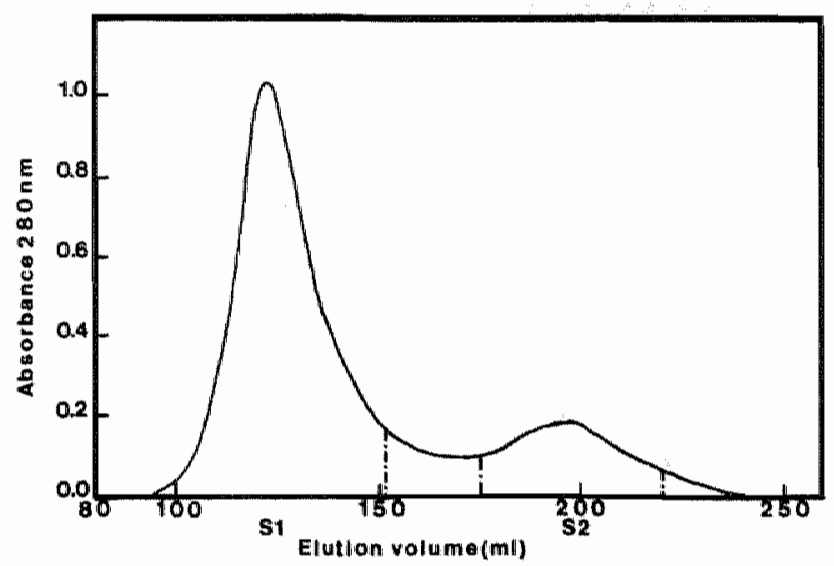

Fig. 2. Gel fittration of the Doc-aupernatant fraction of fradion $I$ on a sephacryt $S-200$ colum in DoC-buffer.

TABLE 1. Induction of delayed hypersenstivity against Listeria monocytogenes with fractions obtalined by gel filtration of a deoxycholate extract of fraction $T$.

Preparation $\quad$ Footpad swelling $\quad \underline{\mathrm{P}}$ value

$(0.1 \mathrm{~mm}) \pm \mathrm{SD}$

\begin{tabular}{lcc}
\hline$S 1+D D A$ & $13.3 \pm 1.4$ & $<0.001$ \\
$S 2+D D A$ & $8.3 \pm 1.8$ & $<0.001$ \\
fraction I+DDA & $8.7 \pm 1.7$ & $<0.001$ \\
$D D A$ & $1.2 \pm 1.1$ & -
\end{tabular}

a Groups of six mice were injected iw. Whth jractiono to be tested in a dose containing $2 \mathrm{~kg}$ protein. Positive controts received $10 \mathrm{~kg}$ (dry weight) fraction. I. Before injection all preparatione were combined with $300 \mu g$ DDA. Negative controle received DDA alone. After bewen daye DH was elicited by footpad challenge with $10^{8}$ formalin-killed Lieteria and read as the increase in footpad thickness 24 h later.

b $\quad$ P values were calculated relative to DDA controls. 


\section{Lon exchange chronatography}

Ion exchange chromatography of fraction 52 resulted in the elution profile pregented in figure 3 . The eluate was fractionated as indicated in the flgure. Fraction Di was eluted with starting buffer and found to be homogeneous by SDS-PAGE (MW 20,400). Upon gradient elution fractions were obtained with a gradually decreasing content of low MW protelns. Fractions D3 and D4 contalined a $67,000 \mathrm{MW}$ protein which was not found in fractions D1 and D2 (fig. 1). All fractlons obtalned by Ion exchange chronatography induced Dif againgt Listeria (table 2 ).

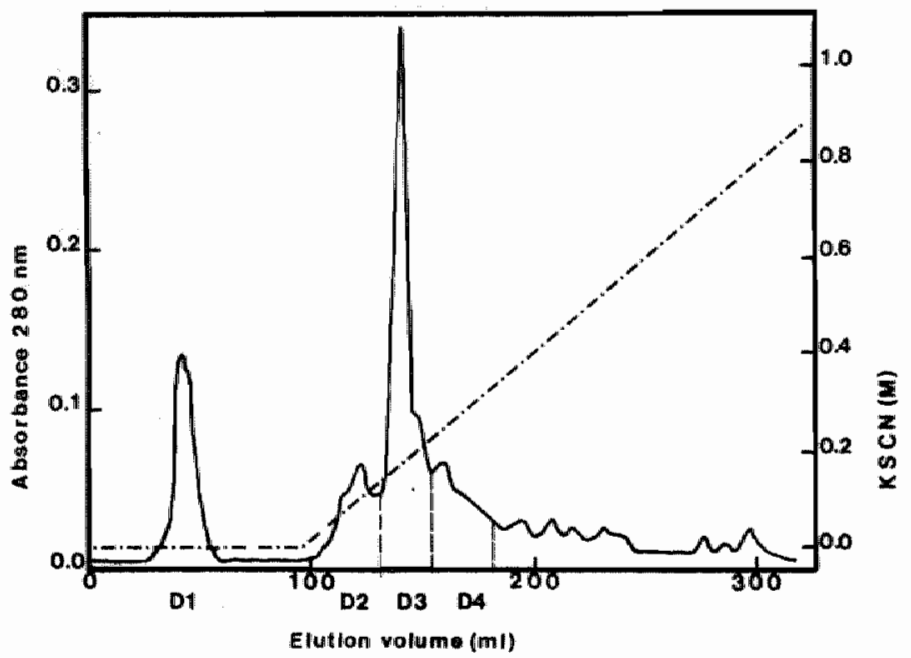

Eig. 3. Ion exchange chmomatography of sephacryl fraction s2 on a $D E A B$ Sepharone $C L-6 B$ colwh in $6 M$ urea buffer.1.-...-KSCN gradienti. . 
TABLE 2. Induction of delayed hypersensicivity agalnst Listeria monocytogenes wh fractions obtalned by ion exchange chromatography of eraction 52 .

\begin{tabular}{lcc}
\hline Preparation & $\begin{array}{l}\text { Foodpad swe111ng } \\
(0.1 \mathrm{~mm}) \pm \mathrm{SD}\end{array}$ & $\underline{\text { P value }}$ \\
\hline $\mathrm{D} 1+\mathrm{DDA}$ & $6.4 \pm 3.6$ & 0.01 \\
$\mathrm{D} 2+\mathrm{DDA}$ & $10.9 \pm 1.4$ & $<0.001$ \\
$\mathrm{D} 3+\mathrm{DDA}$ & $8.6 \pm 2.8$ & $<0.001$ \\
$\mathrm{D} 4+\mathrm{DDA}$ & $8.3 \pm 2.8$ & $<0.001$ \\
fraction I + DDA & $7.1 \pm 3.9$ & 0.01 \\
DDA & $2.3 \pm 0.1$ & -
\end{tabular}

\begin{tabular}{|c|c|}
\hline $\bar{a}$ & 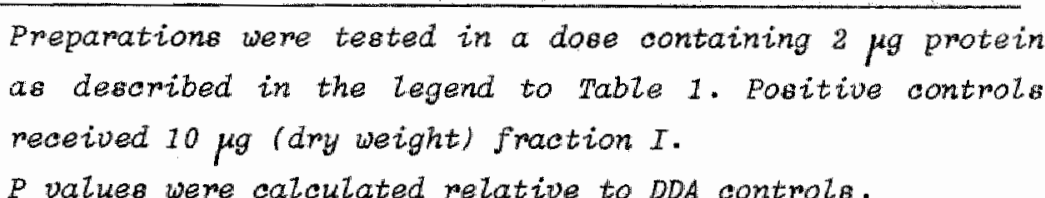 \\
\hline
\end{tabular}

\section{DISCUSSION}

Experiments described in this paper resulted in the purification of a $20,400 \mathrm{MH}$ protein which induced DH against Listerta. Despite the rather drastic conditions used in the lon exchange procedure all fractions obtalned by lon exchange chromatography induced $\mathrm{DH}$.

In this respect $1 \mathrm{t}$ should be noted that the DH response 1 s a $T$-cell mediated reaction. In contrast to the interaction between antigen and antibody which is rather sensitive towards denatura tion of the antigen, recognition of proteln-antigens by T-celis appears to depend mainly on the amino acld sequence of the antigen (7)

Therefore the purification procedure described might also be useful for the puriftcation of other antigens involved in cellular 
Lrmune reactions.

Apparently the $20,400 \mathrm{MW}$ protefn was not the only antigen involved In the Induction of DH agalnat Listeria, because DH could also be induced with fraction D4 which lacked the 20,400 MW component. Wevertheless the avallablituy of purlfled antigen should facilltate the study of the DH response against Listeria which thusfar thas been done using rather complet antigenic mixtures such as complete killed bacterfa (2) ar concentrated and dialysed culture flltrate $(8)$.

\section{REFERENCES}

(1) AnconIssen, A.C.J.M., Lemmens P.J.M.R., Gonggr1jp, R., van den Bosch, J.F. and Van Boven, C.P.A. (1985) Antonie van Le euwe nhoek $51,227-240$.

(2) Van der Meer, C. Hofhuls, F.M.A. and Willers J.M.N. (1979) Immurno $\log y, 37,77-82$.

(3) Van Dijk, H., Versteeg, H. and Hennink, H.J. (1976). J. Immunol. Meth. 12, 261-265.

(4) Korhonen, T.K., Nurmiaho, E-L. "Ranta, H. and Svanborg Eden, C. (1980) Infect* Itrinun. 27, 569-575.

(5) Hartree, E.F. (1972) Ana1. Blochem. 48, 422-427.

(6) Lugtenberg. B., Meijers, J., Peters, R., Wan den Hoek, P. and Van Al phen, L. (1975) FEBS Lett. 58, 254-258.

(7) Tliomas, D.W., Hoffman, M.D. and W1ner, G.D. (1982) J. Exp. Med. $156,289-293$.

(8) Kaufmann, S.H.E., Simon, M.M. and Hahn, H. (1979). J. Exp. Med. 150, 1033-1038. 


\section{CHAPTER 6}

TRANSEER OF ENHA NCED RESTSTAMCE AGA INST

LISTERIA MONOCYTOGENES INDUCED WTIH RIBOSOMAL

RNA AND THE ADTUVANT DIMETHYLDIOCTA DEC YLAMMONIUW BROUIDE'

\section{SUMAARY}

In this study we investigated the mechanism of enhanced resistance against Llsteria monocytogenes Induced with Llaterla ribosomal RNA and the adjuvant dimethyldioctadecylammontum bromide (DDA). Mice imunized with DDA alone (which were not protected against Listeria-infection) were used as negative controles. Mice immunized with RNA plus DDA were found to have an increased capacity to mobilize polymorphonuclear leukocytes (PMNs) and macrophages to the inflamed peritoneal cavity compared to nice immunized with adjuvant alone. Intraperitoneal (1.p.) Inflammation was induced by 1 injection of the sterile irritant proteose peptone. The protective capacity of various cell-populations was Investigated by $1 . p$. transfer of cells to normal reciplent mice and concomitant challenge of reciplent andmals with a lethal dose of viable Listeria. Inflamatory PMNis as well as inflamatory macrophages from mice limmunized wth RNA plus DDA protected reciplent antmals agatnst listerlosis whereas cells from mice immunized with DDA alone falled to do so. Therefore, enhanced mobilization as well as activation of PMNs and macrophages may have contributed to the expression of protection against Llsterla monocytogeneg Induced WIth RNA plus DDA.

\section{INTRODUCT TON}

Listerla monocytogenes is a Gram-positive bactertum which behaves, when it has entered the body, as a facultative intracellular paraste. Its natural host cell ts the macrophage $t$ n 
which the organisn 18 able to survive and even to multply (World Health Organization Scientiflc Group, 1973). Expresston of protecclon agalnst Listerla Induced by imunization with a sublethal dose of vlable bacterla is genera11y considered to require T-cell dependent wacrophage actiwation (Mackaness, 1962, 1969; Worth and Spitalny, 1974). However, recently it was suggested that increased numbers of bactericidal phagocytes accumulating at sites of Listerla-infection rather than macrophage activation (1.e., increased bactericidal activity per celly might be of cruclal importance for the expression of immunity against Listeria) (Czuprynski et a1., 1984).

In the latter study the number of polymorphonuclear leukocytes (PMNs) and macrophages accumulating in the peritoneal cavity of Listeria-immune mice after induction of intraperitoneal inflammation by injection of kilied Listeria or the sterile irritant proteose peptone was found to be considerably higher than the number of cells which accumulated in the peritoneal cavity of nonImmunized mice. However, equal numbers of phagocytes from Listerla-immune and non-imunized mice did not differ in their capacity to k111 Listerla in vitro, 1.e., inflammatory PMNs and Inflammatory macrophages from efther source kflled Listeria, whereas resident peritoneal macrophages failed to do so (Czuprynski et 1.1 .1984 ).

Previousiy we reported that mice could be immuntzed agalnst lechal Listeria infection with ribosomal RNA isolated from Listerla monocytogenes. RNA had to be combined with the adjuvant dimethyldioctadecylammonium bromlde (DDA) to induce protection (Antonissen et 1 . , 1985). Whereas conslderable progress has been made with the eluctdation of the mechanism of protection induced by immunization th viable Listeria (for review, see Hahn and Kaufmann, 1981; Kautmann et a1., 1985; Chen-Woan et a1., 1985), relatively little is known about the mechanism by which Listeria-RMA (Antonissen et a1., 1985) or other non-viable Listerla-vaccines (Rodriguez et a1., 1974; Van der Meer et al., 1979; W11lers et a1., 1979) provide protection. In this paper we report that mice Imunized with RNA plus DDA have an increased capacity to mobIlize 
phagocytes to the laflamed peritoneal cavity as compared to mice treated with DDA alone. Results from passive tranfer-experiments indicated that inflammatory PMNs as well as inflamatory macrophages from mice treated with RNA plus DDA are activated compered to cells from adjuvant-treated mice.

\section{MATERIALS AND METHODS}

Experimental animals

Male BALB/c mice were obtalned from TNO, Central Institute for the Breeding of Laboratory Animals, Zelst, The Netherlands, and used at an age of 8-11 weeks.

\section{Bacteria}

Listerla monocytogenes L.242, serotype 4b, was kindly provided by $\mathrm{H}$. van D1jk, Department of Immunology, University of Utrecht, The Netherlands. Mouse-passaged bacteria were grown for $16 \mathrm{~h}$ at $37^{\circ} \mathrm{C}$ as described previously (Antonissen et al. 1981). Culture bottles were fitted with $0.22 \mu$ filters to release pressure. Bacterla were recovered by centrifugation, washed three times with phosphate-buffered saline pH 7.0 (PBS) and stored In small portions at $-70^{\circ} \mathrm{C}$ in PB. The concentration of viable bacterla in thawed stack suspensions was estimated by plating on Trypticase Soy Agar (BBL Microblology Systeme, Cockeysville, MD, U.S.A.)

To determine the $50 \%$ lethal dose $\left(L_{50}\right), 0.5$ mil of oerial dilut lons of a stock suspension of bacterla were injected lntraperitoneally (1.p.) into mice. Deaths were recorded for 14 days. The $\mathrm{LO}_{50}$ was calculated according to Reed and Muench (1938). For the batch used in this study the $\mathrm{LD}_{50}$ was $2.6 \times 10^{6}$ collony forming units.

Ribosoma1 RNA; DDA

Ribosomal RNA from Listerla monocytogenes was prepared as described previously (Antonissen et al., 1985) using procedures originally developed for the purification of rRMA from Pseudomonas aeruginosa (Gonggrijp et a1., 1980, 1981). The purified RNA con- 
talned less than $1 \%$ residual protein. It was stored at $-70^{\circ} \mathrm{C}$ in PBS.

DDA (Eastman Kodak Co., Rochester, N.Y.) was suspended in PBS by brlef sonlcation immediately before use. The suspension contalned 3. mg DDA per mI PBS.

Inisunization with RMA

MLce were Lnjected 1.P. With $10 \mu \mathrm{g}$ RNA plus $300 \mu \mathrm{g}$ DDA in 0.2 all PBS. Controls recelved DDA alone (Antonissen et al., 1985).

\section{Iminunization with viable Listeria}

Mice were Immunized $1 \cdot P$. with 0.1 LD $_{50}$ Listeria (Czupryoski et al., 1984). Each mouse received $0.2 \mathrm{ml}$ L1steria-vaccine, which was prepared by approprlate dilution of a stock suspension of bacteria with PBS. Controls recelved $0.2 \mathrm{ml}$ PBS.

\section{Collection of resldent and inflammatory peritoneal cells}

Resident and inflammatory peritoneal cells were collected using modiflcations of procedures described by Czuprynakl et al. (1984). To obtain inflammatory cells, mice vere injected 1.p. With 1 m $10 \%$ proteose peptone (Oxold Ltd., Basingstoke, Hants, England). At 4,24 or 48 h after injection of proteosie pieptone mice were killed by ether overdose. Inflammatory cells were collected by peritoneal lavage wth $4 \mathrm{ml}$ cold Hanks balanced salt solution (HBSS). Cells were recovered by centrifugation (300xg for $10 \mathrm{~min} \cdot$ ), washed 3 times with HBSS contalning $0.25 \%$ bovine serum albumin (HBSA), and counced with a hamacytometer. Differential counts were performed on smears prepared from cells suspended in newborn calf serum. Smears were stalned with May Grunwald-Glemsa, and scored for PMNs, lymphocytes and monocytes/macrophages (macrophages). The same procedure was used for the collection of resident peritoneal cells, except that the $\mathbb{1 n j e c t i o n}$ of proteose peptone was omitted.

Separation of polymorphonuclear leukacytes and macrophages

PMNs and macrophages were separated using a discontinuous gradient of Nycodenz (Nyegaard Co., Osilo, Norway). A stock 
solution of $90 \%(\mathrm{v} / \mathrm{v})$ Nycodenz containing 10 mM LDTA was prepared by 9 to 1 dllution of isotonic Nycadenz (as supplied by the manufacturer) With $100 \mathrm{mM}$ EDTA, $\mathrm{pH} 7.0$. Solutions of $70 \%$ and $53 \%$ Nycodenz were prepared by dilution of $90 \%$ Nycodenz with HBSS containing 10 EDTA (HEDTA). Peritoneal cells were collected with HEDTA, sedimented by centrifugation and suspended in $70 \%$ Nycodenz to a maximum of $1.25 \times 10^{7}$ cells/m. Three-layer gradients were prepared in $50 \mathrm{ml}$ conlical polypropylene tubes (type 2070F, Falcon Plastics, Oxnard, Callfornia, USA) and consisted of $12 \mathrm{~m} 1 \mathrm{HEDTA}, 16 \mathrm{ml} 53 \%$ Nycodenz and $12 \mathrm{ml} 70 \%$ Nycodenz containting the cells.

Gradients were spun at $4^{\circ} \mathrm{C}$ for $30 \mathrm{mln}$ at $400 \times \mathrm{g}$. Macrophages and PMNs were collected from the HEDTA/53\% Nycodenz and the 53\%/70\% Nycodenz interface, respectively, and washed three times with HBSA. Macrophages and PMNs were obtalned in 80-92\% and 87-93\% purity, respectively. The yleld of purifled cells was approximate1y $40 \%$. More than $90 \%$ of the cells were viable as measured by trypan blue exclusion.

Transfer of protection

The protective capacity of various cell populations was determined by transfer of cells to normal reclplent mice and concomitant challenge of recipient animals with a lethal dose of viable Listeria. Each mouse was injected $1 . p$. With the appropriate numer of cells and approximately $4.5 \mathrm{LD}_{50}$ Listeria in $0.5 \mathrm{ml}$ pas. Cells were combined with the Listerif-challenge by resuspensiou of sedimented cells in a diluted stock suspension of bacterla in PBS. Controls recelved the Listerla-challenge without cells. The percentage of survivors was determined after 14 days.

\section{Statistical evaluation}

Signiffcance levels for protection were determined by the Elsher exact test (Bradley, 1968). Differences were considered to be signiflcant at $\underline{\mathrm{P}}$ values $<0.05$. 
RESULTS

Correlation of protection Induced wth RNA plus DDA the enhanced phagocyte Inflamatory responses

Prevloubly we reported that mice were highly protected agalnst Libterta-infection seven days after $1 . p$. Injection of 10 Hg RNA plus $300 \mathrm{Hg}$ DDA, whereas mice treated with DDA alone, RNA alone, or PBS dled after challenge with Listeria (Antonissen et al. * 1985). To investigate whether protection induced with RNA plus DDA was associated with enhenced phagocyte inflamatory responses, groups of 28 mlee were Immunized 1.p. with 10 Hg RA plus 300 fig DDA. Controls recelved DDA alone. To obtaln a positive control for increased inflammatory responsiveness, mice immunized with 0.1 $\mathrm{LD}_{50}$ vlable Liaterta were lncluded in the experlment (Czuprynski et a1., 1984). Milce treated with PBS were used as negative controls. Seven days after vartous treatments sever mice of each group were used to collect resident peritoneal cells. The remalning wice were injected $1 . p$. Wh th 1 ml $10 \%$ proteose peptone to obtain inflammatory peritoneal cells. Inflamatory cells were collected at 4,24 , and $48 \mathrm{~h}$ after 1 njection of proteose peptone, using seven intce of each group at each time. Total and differential counts were performed on pooled cells from seven mice. The mean result of two experiments is given in $\mathbb{F} 1 \mathrm{~g}$. 1A. The most atiking effect of Immunization of mice with RNA plus DDA was the thastive number of PMNs collected 4 h after injection of proteose peptone whlch was more than fourteen times as high as the number of resldent peritaneal PMNs and more than three times as high as the number of Inflammatory PMNs collected from DDA-pretreated mice. Four hours exudates from mlce immunized with RNA plus DDA also contalned elevaced numbers of macrophages compared to restdent peritoneal cells as well as compared to $4 \mathrm{~h}$ exudates from DDA-Immuitized mice. Therefore, pratection induced with RNA plus DDA was positively correlated with enhanced inflamatory responses of PMNs and macrophages. Differences between mice treated with RNA PIus DDA and DDA-treated mlce with respect to the number of inflamatory peritoneal cells appeared to be of a transient 
nature, as mice subjected to either treatment contalmed approximately equal numbers of peritoneal cells (predominanty macrophages) at $48 \mathrm{~h}$ after injection of proteose peptone. As expected, mice inmunized with wable Listerte mobllized increased numbers of PMNs and macrophages to the inflamed peritoneal cavity compared to mice treated with PBS.

Transfer of protection with resident and inflammatory peritoneal cells

To investigate the contribution of resident and lnflammatory peritoneal cells to the expression of protection against Listeria, the cell populations described in the previous section (Fig. LA) were transferred to nomal recipient mice using groups of $s$ lx animals for each cell population to be tested. Each reclplent mouse received one seventh part of pooled cells from seven mice, resultiag in a donor to acceptor ratio of 1:1. The Listeriachal lenge (approximately $4.5 L_{50}$ per mouge) was lincorporated in the suspension of cells to be transferred. Reclpient mice were injected 1.p. With $0.5 \mathrm{ml}$ of a mixture of cells and Listerla in $0.5 \mathrm{~m} 1$ PBS. Controls recelved the Listeria-challenge without cells. The mean result of two experiments is presented in Fig* IB. Resident as well as 4 and 48 h inflammatory cells collected from mice pretreated with RNA plus DDA conferred a significantly higher level of protection to recipient mice than the corresponding cell populations collected from mice pretreated with DDA. However, protection conferred by 4 and 48 inflamatory cells was higher and less variable than the protection conferred by resident peritoneal cells. All cell populations collected from ande lmmunized with viable Listerla conferred a high level of protection to Listeria-infection compared to cello collected from PBS-pretreated mice. Forty five out of 48 mice $(94 \%)$ recelving the Listeria challenge but no cells died from listertosis (data not shown).

Contrlbution of inflammatory macrophages and inflammatory PMNs to the expression of protection induced with RNA plus DDA

At $48 \mathrm{~h}$ after the injection of proteose peptone peritoneal 

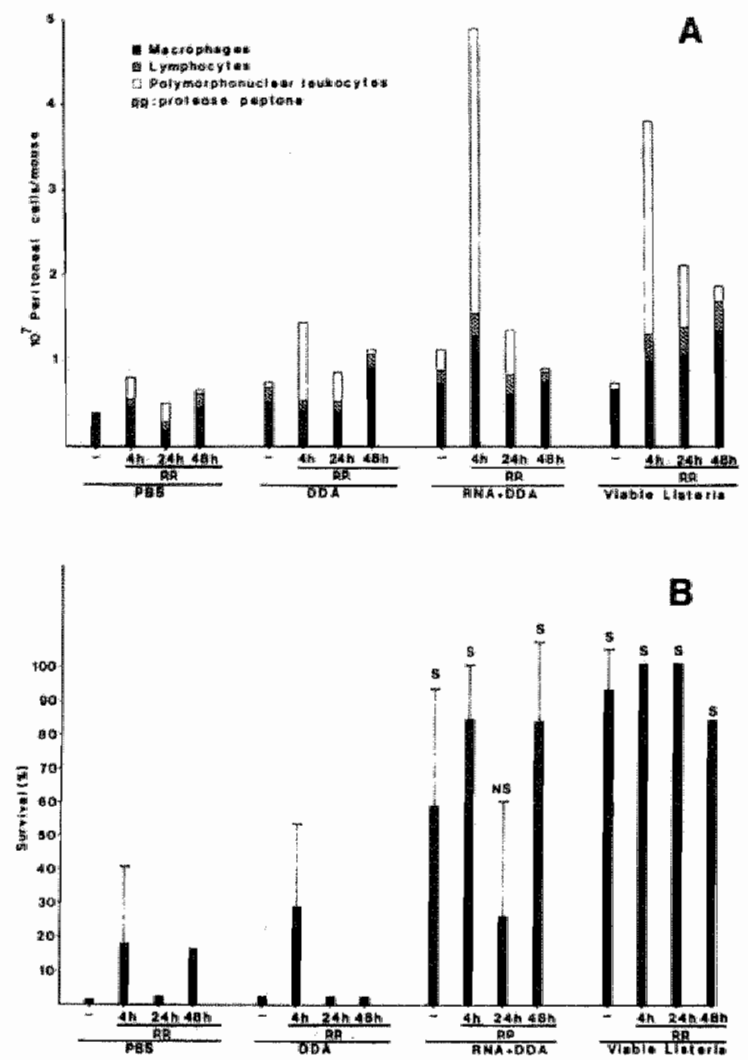

EIG. 1. Modutation of phagocyte imflammatory reaponses with RNA plus DDA and transfer of protection with reatdent and inflamatory peritoneal cetts. 
A Groups of seven mice were injected $i$.p. with $10 \mathrm{pg}$ RNA plus DDA or with DDA alone. Mice immunized it. with $0.14 D_{50}$ viable Listeria and mice treated with $P B S$ were used as poritive and negative controls, respectively. Seven days later resident peritoneal cells $(-1$ were collected by pertomeal zavage. Inflammatory cello were obtained by $i . p$. injection of proteose peptone seven days after various pretreatments and collection of cells 4,24 or 48 h later (mean pesult of two experiments).

$B$ The protective capacity of resident and inflamatory oetzo as described in Fig. IA wze investigated by $i . p$. transfer to groups of aix nomal recipient mice, using a donor to acceptor ratio of 1:1. Before transfer donor cells were cambined with 4.5 LD 50 Liateria monocytogenes. The pereentage af survivora was determined 14 days later. Reaults represent the mean of two experiments $+S D$. SD vatues not indiacted were zero. Significance levels of protection conferred by celt derived from RNA plus DDA treated mice and by cello from Lititeria immunised miae were calculated relative to DDA and PBS controls, mespectively. (S* significant; NS: not significant). 
exudates from mlce lnunized wth RNA plus DDA or DDA alone contalned approximately equal numbers of cells which were predominantly macrophages (Flg. LA). However, only cells collected from mice lamuntzed with RNA plus DDA protected recipleat andmals agalnst listerlosis (P1g. 1B). Therefore, protection conferred by 48 h inflammatory cells from ice Imunized with RA plus DDA was most 11kely due to activated macrophages.

To invertigate whether protection conferred by $4 \mathrm{~h}$ inflammatory cells from mice lmmunized with RNA plus DDA was due to PMNs or macrophages, these cells were separated by gradient-centrifugation. Groups of six nornal reciplent mice were injected $1 . p$. with $10^{7}$ purifted PMNs or $10^{7}$ purfifled macrophages from mice immunized With RNA plus DDA or wh the same number of purifled cells from mice Immuntzed with DDA alone. Before transfer cells were combined with a lethal dose of viable Listeria as already described. Controls consisted of groups of s1x mice treated with $10 \mu \mathrm{g}$ RNA plus DDA or DDA alone and a group of six mice not subjected to any treatment at all. Controls recelved the Listerla-challenge but no cel1s. The mean result of two experiments is presented 1 in Fig. 2 . PMNs from mice pretreated with RNA plus DDA protected recipient mice agalnst listeriosis, but PMNs from DDA-pretreated mice and macrophages from elther source did not. Therefore, protection conferred by 4 h inflammatory cells from mice immunized with RNA plus DDA appeared to be largely due to PMNs whlch were activated compared to PMNs from mlce immunized with DDA alone.

\section{DLSCUSSION}

Data presented in this paper indlcate that mice lumunized with RNA plus DDA had an Increased capacity to mobilize phagocytes (PMNs as well as macrophages) to the inflamed peritoneal cavity compared to wice treated with DDA alone. The most striking effect of treatment of mice with RNA plus DDA was the massive number of PMNs which could be collected 4 h after i.p. Injection of proteose peptone. In fact, mice treated with RNA plus DDA mobilized even more PMNs to the Inflamed peritoneal cavity than mice immunized 


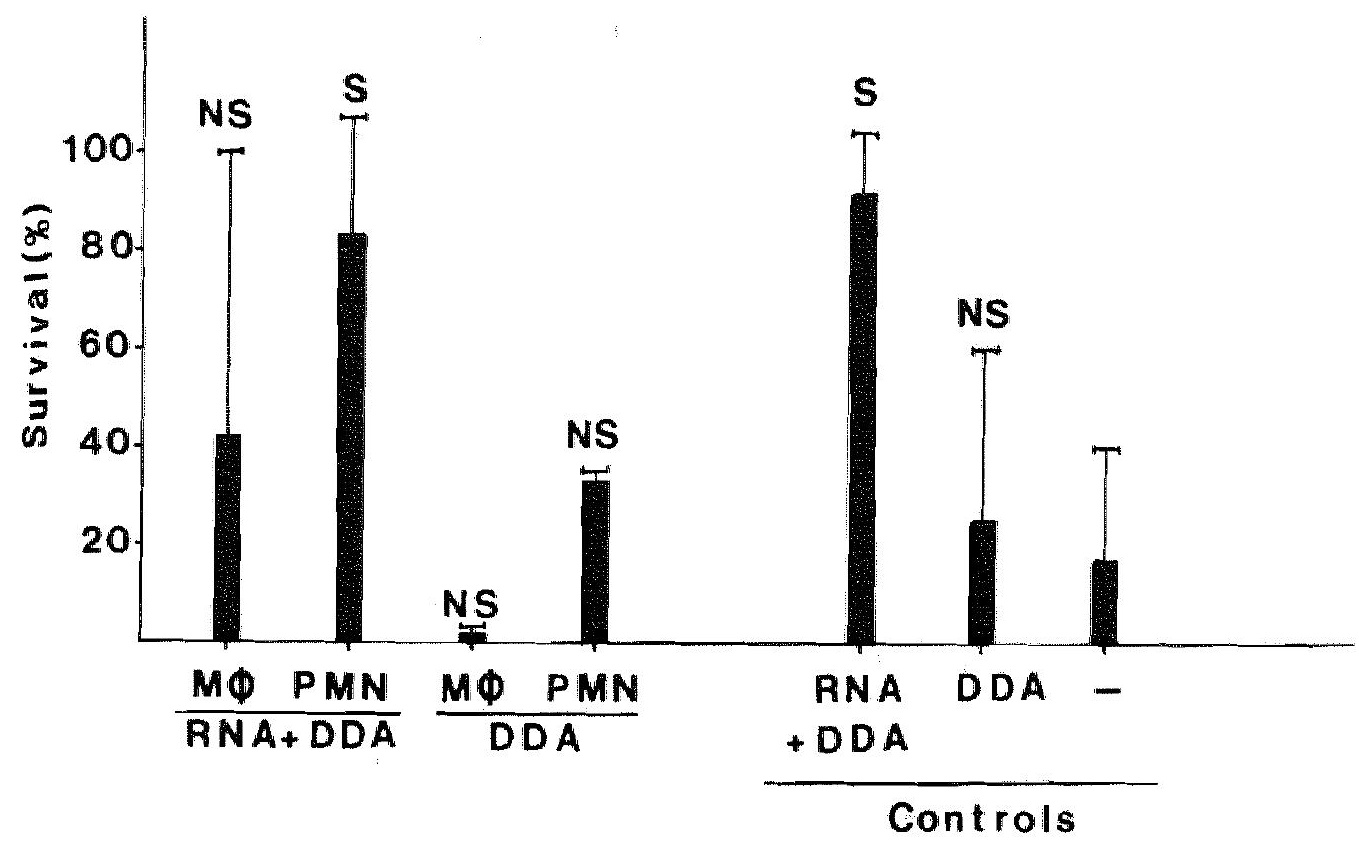

FIG. 2. Thansfer of protection with purified inflamatory FMNe and mac pophages:

Mice were injected i.p. with $10 \mu g$ RNA plus $300 \mu \mathrm{g}$ DDA or with DDA alone. After aeven days mice were injected i.p. with $1 \mathrm{ml}$ 10\% proteose peptone. Inflanmatomy aells were collected $4 \mathrm{~h}$ later and separated by gradient centmifugation.

Groupe of six nomal mice were injeoted $i$. with $10^{7}$ purified PMNa or macrophage (Mo) in combination with $4.5 D_{50}$ viabie Liateria. Groups of six mice inmunitad aeven days previouty with RNA plus DDA or DDA alone and a group of mice having rece ived wo treatment at alt $(-)$ were used at controts. Controle received the Listeria-challenge but no cells. The pereentage of survivors was determined 14 daye later. Results represent the mean of two experiments + SD. $P$ values were caloulated relative to untreated controts (-). (S: Bignifiaant; NS: not bignifiaant). 
Wth plable Llsterla (FLg. LA). Furthermore, PMNs from mice treated Wth RNA pluS DDA were found to be actlvated compared to cells from mlce treated with DDA alone (Fig. 2). To our knowledge this is the first report lmplicating the phenomenon of PAN-activation in the expression of protection against Llsteria monocyto-

genes. Wht few exceptlons (Czupryaskl et a1, 1984; McGowan et 1. 1983) the contribution of PMNs to the expression of protection agalnst Listerla seems to have been largely overlooked. posisibly because these cells rapldiy disappear after entering a ste of inflamation (Fig. LA; Czuprynsk1 et al., 1984). Transfer experiments with $48 \mathrm{~h}$ inflamatory cells indicated that in addition to PWN-activation, activation of macrophages contributed to the expression of protection with RNA pllus DDA (Fig. LA, B). In this study the protective capacity of varlous cell-populations was Investigated by pasive transfer rather than by in vitro bactericldal assays because the latter tend to produce highly conflicting results (for revlew, see cauprynsky et al., 1984) and may not reflect differences in antibacterial resistance observed in vivo (Czuprynski et al., 1984; Gonggrijp et a1., 1985).

As enhanced Inflammatory responstveness and activation of phagocytes (at least of macrophages) appear to be common features of protection induced with RNA plus DDA and protection induced by immunization with viable Listeria (Mackaness, 1962, 1969; Czuprynak1 et a1., 1984; North and Spltalny, 1974) one might speculate that the mechanlsm of protection induced with RMA plus DDA Is similar if not identical to the mechanism of protection induced by imunization wth viable Listerla. However, several observatlons point to the contrary. In contrast to viable Listeria, RNA plus DDA did not induce delayed hypersensteivity agatingt Listeria-antigens (Antonissen et a1., 1986). Furthermore, cyclosporin A, which inhibits the Induction of T-cell dependent Immuntey against Listeria (Schaffner, Douglas and Dav1s, 1983), did not 1 nhibit the Induction of protection with RMA plus DDA (Van den Bosch et al., 1985). Therefore, protection induced with RNA plus DDA was probably due to a $\mathrm{T}$-cell independent rather than to a $\mathrm{T}$-cell dependent modulation of phagocyte functions which might 
also explain why the overall protection conferted by cell populations from mice immunized wh viable Ligteria was higher than the overall protection conferred by cells from mice immunized with RNA plus DDA (FIg . 14 , 1B).

Finally, our observatlons with respect to the effect of RNA plus DDA on phagocyte inflamatory responses corroborate several other reports indicating that enhanced inflamatory responsiveness is a highly conserved feature of various types of resistance to $11 \mathrm{~s}^{-}$ teriosis tacluding nonspecifically enhanced resistance (1.e., protection Induced by preparations unrelated to Llsterla monocytogenes) (Fauchère et a1*, 1982), genetlcally determined natural reslstance (Czuprynski et al., 1985; Stevenson et al., 1981), and protection induced by immunization with viable Listerla (Czuprynski et al., 1984).

\section{REFERENCES}

Antonlssen, A.C.J.M., Lemmens P.J.M.R., Gonggrijp, R., van den Bosch, J.T., and Van Boven, C.P.A. (1985). RNase-sensitive and RNase-insensitive protective components Isolated from Listerla monocytogenes. Antonie van Leeuwenhoek 51, 227-240.

Antonissen, A.C.J.M., Lemmens, P.J.M.R., Van den Bosch, J.F., and Van Boven, C.P.A. (1986). Dissociation between enhanced resistance and delayed hypersensitivity induced wh th subcellular preparations from Listerla monocytogenes and the adjuvant dimethyldioctadecylammonium bromide. Antonle van Leeuwenhoek $52,75-84$.

Antonlssen, A.C.J.M., Van Kessel, K.P.M., Van Dijk, H., and Willers, J.M.N. (1981). Development of a simple passive haemagglutination-inhibition assay for Listerla monocytogenes 11 potelcholc acid. J. Immuno1. Methodis 44, 351-357.

Bradley, J.W. (1968). Distribution free statistical tests. Prentice Hall Inc., Englewood Cllffs, N.J.

Chen-Woan, M., Sajewsk1, D.H., and McGregor, D.D. (1985). T-cell co-operation in the mediation of acquired resistance to Listeria monocytogenes. Immunology 56, 33-42. 
Czuprynski, C.J., Canono, B.P., Henson, P.M., and Campbe11, P.A. (1985). Genetically determined resistance to listeriosis is assoclated wth increased accumulation of inflamatory neutrophlls and macrophages which have enhanced listericidal activity. Imunology 5,5, 511-518.

Czuprynski, C.J., Henson, P.M., and Campbe11, P.A. (1984). K1111ng of Listerla monocytogenes by inflammatory neutrophils and mononuclear phagocytes from immune and nonlmmune mice. J. Leuk. Biol. 35, 193-208.

Fauchère, J.L., Simonet, M., and Veron, M. (1982). Non-speciflc resiatince of mice to bacteria, induced by an acellular extract from Pseudomonas aeruginosa. Ann. Immunol. (Inst. Pasteur) $133 \mathrm{C}, 333-347$.

Gonggrijp, R., Mullers, W.J.H.A., Dullens, H.F.J., and Van Boven, C.P.A. (1985). Antlbacterial resistance, macrophage influx and activation 1 nduced by bacterial rRNA with dimethyldioctadecylammontum bromide. Infect. Immun. 50,728-733.

GonggrLJP, R., Mullers, W.J.H.A., Lemmens, P.J.M.R., and Van Boven, C.P.A. (1980). Ribonuclease-sensitive ribosomal vacclne of Pseudomonas aeruginosa. Infect. Immun. 27, 204-210. Gonggr1jp, R., Mullers W.J.H.A., and Van Boven, C.P.A. (1981). Serotype-nonspecific protection induced by ribonucleid actd isolated from the ribosomal vaccine of Pseudomonas aeruginosa. Infect . Immun. 33, 178-185.

Hahn, H., and Kaufmann, S.H.E. (1981). The role of cel1-medlated tmmuntey in bacterial infections. Rev. Infect. Dis. 3 , $1221-1250$.

Katutinan, S.H.E., Hug, E., Väth, U., and Muller, F. (1985). Effective protection against Listeria monocytogenes and delayed-type hypersensitivity to 1 isterial antigens depend on cooperation between specific $\mathrm{L}_{3 \mathrm{~T}} 4^{+}$and $\mathrm{Lyt} 2^{+} \mathrm{T}$ cells. Infect. Immun. 48, 263-266.

MacGowan, A.P., Peterson, P.K., Keane, W., and Quie, P.G. (1983). Human peritoneal macrophage phagocytic, killing and chentlurinescent responses to opsonized Listeria monocytogenes. Infect. Immun. 40, 440-443. 
Mackaness, G.B. (1962) Cellular resistance to infection. J. Exp. Med. 116, $381-406$.

Mackaness, G.B. (1969). The influence of imunologlcally committed 1 ymphoid cells on macrophage activity in vivo. J. Exp. Med. $129,973-992$.

North, R.J., and Spltalny, G. (1974). Inflamatory 1ymphocyte in cell-mediated antibacterial immunlty: factors governing the accumulation of mediator $T$ cells in peritoneal exudates. Infect. Inwun. 10,489-498.

Reed, L.J., and Muench, H. (1938). A simple method for estimating fifty per cent endpoints. Am. J. Hyg. 27, 493-497.

Rodriguez, G.E., Macclatchy, J.K., and Campbe1l, P.A. (1974). Induction of resistance by Listeria monocytogenes cell wall fraction. Infect. Immun. 10, 1163-1169.

Schaffner, A., Douglas, H., and Davis, C.E. (1983). Models of $\mathrm{T}$-cell deflciency in 1isteriosis: The effect of cortisone and cyclasporin A on normal and nude BALB/C mice. J. Immunol. $131,450-453$.

Stevenson, M.M., Kongshavn, P.A., and Skamene, E. (1981). Genet1C linkage of resistance to Listeria monocytogenes with macrophage inflammatory responses. J. Immunol . 127, 402-407.

Van den Bosch, J.F., Kanis, I.Y.R., Antonissen, A.C.J.M., and Van Boven, C.P.A. (1985). Mechanism of protection induced by ribosomal ribonucleic acid from Ligterla monocytogenes. Antonle van Leeuwenhoek 51, 515-516.

Van der Meer, C., Hofhuis, M.M.A., and Willers, J.M.N. (1979). Delayed-type hypersensitivity and acquired cellular resistance in ince immunized wth ktlled Listerta monocytogenes and adjuvants. Immunology $37,77-82$.

Willers, J.M.N., Bloksma, N., Van der Meer, C., Snippe, H., Van Dijk, H., de Reuver, M.J., and Hofhu1s, E.M.A. (1979). Regulation of the immune response by macrophages. Antonie van Leeuwenhoek 45, 41-48.

World Health Organization Scientiflc Group (1973). Cell medlated immunity and resistance. WHo. Techn. Rep. Ser. 519, 6-64. 


\section{CHAPTER ?}

PROTECTION AGA INST LISTERIA MONOC MTOGENES INDUCED WITH NATURAL AND SYNTHETIC RNA COMBLWED WITH THE ADUUVANT DIMETH YLD IOCTA DEC YLAMMONIUM BROMIDE:

CORRELATION WTH ENHA NCED PHA GOCYTE INRLAMMATORY RESPONSES

SUMMARY

In this study we investigated the effect of synthetic RNA's and polyantions on the resistance of mice to infection with Listeria monocytogenes to gain further insight with respect to the mechanism of protection against listeriosis induced with ribosomal RNA from Listerla monocytogenes. All substances were tested in comblnation with the adjuvant dimethyldloctadecylammontum bromide (DDA) which is required for the lnduction of protection with ListeriaRNA. From a number of substances tested, only poly A:U approached the protective capacity of Listeria-RNA.

Mice treated with protective RMA's (poly A:U and Listeria-RNA) plus DDA had an increased capacity to moblilize polymorphonuclear leukocytes to the inflamed peritoneal cavity as compared to mice treated with a non-protective RNA (poly I:C) plus DDA or mice treated ith adjuvant alone. Therefore, the induction of a state of enhanced inflammatory responslveness appeared to be a cruclal factor with respect to the mechanlsm of protection linduced with RNA Plus DDA.

\section{INTRODUCTION}

Previously we reported that mice could be protected against lethal Listeria Infection with ribosomal RWA from Liateria monocytagenes combined with the adjuvant dimethyldioctadecylammonium bromide (DDA) (Antonissen et al., 1985). Mice 1mmunized with RNA plus DDA had an increased capacity to mobilize phagocytes 
(1 in particular polymorphonuclear leukocytes (PMNs)) to the inflamed peritoneal cawlty which compared favourably with the enhanced inflamatory responsiveness of mice immunized wh viable Llsteria (Chapter 6). Therefore, enhanced inflammatory responsiweness appeared to be a comon feacure of the effector phase of protection againgt Listerla induced by lmmuntzation with vlable Listeria and enhanced reslstance induced 1th RWA plus DDA. To gain further insight with respect to the mechanlsm of protection Induced with RNA plus DDA, it was decided to Lnvestigate whether Listeria-RNA could be substituted by synthet1c RNA's or other polyanions. From a number of substances tested only poly $A: D$ approached the protective capaclty of Isterta-RNA. Protection induced with poly A:U was associated with enhanced Inflamatory responsiveness as previously described with respect to the enhanced resistance induced with Liteterla-RNA (Chapter 6).

\section{MATERIALS AND METHODS}

\section{Experimental animals}

Male BALB/C mice were obtalned from TNO, Central Institute for the Breeding of Laboratory Animals, Zelst, The Netherlands, and used at an age of 8-11 weeks.

\section{Bactersa}

Listeria monocytogenes L242, sterotype 4b, was obtained and cultured as described previously (Antonisgen et a1., 1985). Challenge Inocula were prepared from stock suspensions of bacteria kept at $-70^{\circ} \mathrm{C}$ in phosphate buffered saline, $\mathrm{pH} 7.0$ (PBS). The mean lethal dose $\left(\mathrm{LD}_{50}\right)$ of the batch of bacterla used was $2.6 \times 10^{6}$ colony forming unitg for the Intraperitomeal (1.p.) route of infection.

Polyribonucleotides and other polyanions; DDA

Ribosomal RNA from Llsteria monocytogenes was prepared as described prevlously (Antonissen et al., 1985). The synthetic double-stranded RNA poly A:U was purchased from Boehringer 
Mannheim (Mannheim, W. Germany). Poly I:C, poly A, poly U, and the random copolymers poly (A, U) and poly (I, C) were purchased trom Pharmacia P-L Blochemicals (Uppsala, Sweden). Symthetic polynucleotides were dissolved 11 PBS by heating to $50^{\circ} \mathrm{C}$, allowed to cool to room temperature, and stored at $-70^{\circ} \mathrm{C}$. The polyanionic dyes poly $B-411$ and poly $\mathrm{R}-478$ were obtalned from Janssen Chinica (Beerse, Belgium).

Lipotelchoic acid (LTA) from L. monocytogenes L242 was prepared as follows: Bacteria were suspended in $0.9 \% \mathrm{NaCl}$, frozen at $-20^{\circ} \mathrm{C}$, and discupted using a cold Hughes pressure cell. The broken cell suspension was supplemented with $10 \mathrm{mM} \mathrm{MgCl}_{2}$ and treated with DNase to reduce viscosity (Gonggrijp et al., 1980). After DNasetreatment and addition of EDTA to a concentration of $20 \mathrm{mM}$, the preparation was centrifuged $(16,000 \mathrm{x}, 30 \mathrm{~min})$ to remove cell walls and unbroken cells.

The supernatant solution contalning fragmented membranes was lyophilized and delipidated by extraction with chloroform-methanol (Coley et a 1., 1975). Crude LTA was extracted with hot $\left(60^{\circ} \mathrm{C}\right.$ ) ayuous phenol (Coley et al., 1975) and digested with RNase and proteinase K (Antonissen et al., 1985). Enzymes were removed by extraction with phenol at room temperature (Coley et al, 1975). The aquous phase of the second phenol extraction was dialysed against water and lyophilized. The lyophlilzed materlal was fractionated using a column of Sephacryl S-400 equilibrated with $0.2 \mathrm{M}$ ammonium acetate. Three phosphorus contalning fractions were obtalned, the first of which was identifled as LTA. It contalned hexoses, fatty acid residues, glycerol and phosphate in molar rat $10^{\prime} s$ of $0.39,0.14,1.04$, and 1.00 to phosphate, respectively. Hexoses were determined using the anthrone method as described by Herbert et al. (1971), with glucose as the standard. Fatty acld residues were converted to methyl esters with Br 3 -methanol (Morrison and Smith, 1964) and estimated colorimetrically (snyder and scephens, 1959) using glycerol tributyrate as the standard. Glycecol was determined enzymatically (Hagen and Hagen, 1962) after actd hydrolysis of samples and conversion of glycerol phosphate to glycerol with alkaline phosphatase (Decker et al., 1972). 
Phosphate was determined as described by Rouser et a1. (1966). DDA (Eastman Kodak Co., kochester, N.Y.) was suspended in PBS by brlef sontcation imediately before use. The suspension contalned 3 mg DDA per m1 PBS.

Immuntzation and challenge of mice

Procedure for the lmmunization and challenge of mice were as described prevlously (Antonissen et a1., 1985). Briefly, preparatlons to be tested were appropriately diluted with PBS and 1njected 1.p. Into mlce. Before injection preparations were combined with $300 \mu$ of the adjuvant DDA. Controls recelved DDA alone. After seven day ilce were challenged $1 . P$. wh $10 L_{50}$ Listerla monocytogenes suspended in $0.5 \mathrm{ml}$ PBS. The percentage of survivors was deterained 14 days after challenge.

\section{Assay for enhanced Inflammatory responstveness}

The total and differential score of resident and $4 \mathrm{~h}$ inflamnatory peritoneal cells was determined seven days after varlous treatments as described previlously (Chapter 6; Czuprynski et al., 1984). Brlefly, realdent peritoneal cells were obtalned by peritoneal lavage of mice with 4 mi cold Hanks" blanced salt solution. Inflamatiory perttoneal cells were collected $4 \mathrm{~h}$ after $1 . \mathrm{p}$. injection of $1 \mathrm{ml} 10 \%$ proteose peptone. Dlfferential counts were performed on smears prepared from cells suspended ln newborn calf serum after stalning wh May Grunwald-Giemsa.

\section{Statlatlcal evaluation}

Significance levela for protection were determined by the Fisher exact test (Bradley, 1968). The effects of varlous treatments on phagocyte inflammatory responses were analysed statistically using Wilcoxon"s rank-sum test (Bradley, 1968). For both tests differences were consldered to be slgniflcant at $\mathbb{P}$ values $<0.05$. 
RESULTS

Induction of protection wh symthetic RNA's and polyanions

To investigate whether protection agalnst Listeria could be induced with synthetic RNA"s, mice were Injected 1.p. Wth poly A:U or poly $I: C$ combined with the adjuvant DDA. Negative controls recelved DDA alone. Positive controls recelved 10 Hg Listeria-RNA plus DDA. Seven days later all groups were challenged 1.p. with 10 $\mathrm{LD}_{50}$ Listeria monocytogenes. As shown in Table 1 , mice treated with poly A:U plus DDA were protected against Listeria infection, whereas mice treated with poly I:C plus DDA or DDA alone died from Iisteriosis. Dther substances which were non-protective in the dose in which they were tested (which 18 glven parenthetically) were: poly $(I, C)(10 \mu g, 100 \mu g)$, poly B-411 (10 $\mu g, 100 \mu g)$,

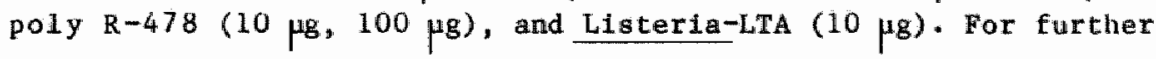
characterization of the protection induced with poly A:U, we also tested poly A alone, poly U alone, and the random copolymer poly (A, U). As shown in Table 2, all of these substances falled to induce protection against Listerla.

Correlation of protection induced wth synthetic RNA's with phagocyte Inflammatory responses

Groups of 12 mice were injected $i \cdot p$. with $100 \mu \mathrm{g}$ poly A:U plus DDA, $100 \mu g$ poly I:C plus DDA, $10 \mu \mathrm{g}$ Listerla-RNA plus DDA or DDA alone. Seven days later $1 \times$ mice of each group were used to determine the number of resident peritoneal PMNs and macrophages. To investigate the effect of varlous treatments on phagocyte linflam matory responses, the remalning inlce were injected $1 . p$. with $1 \mathrm{ml}$ $10 \%$ proteose peptone.

Inflammatory peritoneal cells were collected 4 h after the injection of proteose peptone. As shown in Fig. 1, the effects of treatment of mice with $100 \mu$ poly A:U plus DDA were similar to the effects of $10 \mu \mathrm{Hg}$ Listeria-RWA plus DDA. Upon 1.p. Injection of proteose peptone mice treated with RNA plus DDA or poly A:U plus DDA mobllized Increased numbers of PMNs to the inflamed peritoneal cavity as compared to mice treated with DDA alone. Furthermore, 
TABLE 1: Induction of protection against Listeria with synthetic RNA

\begin{tabular}{rll}
\hline Treatient of mice & Survival $^{\mathrm{b}}$ & P value \\
\hline $10 \mu 8$ poly A:U + DDA & $4 / 6$ & 0.01 \\
100 Hg poly A:U + DDA & $16 / 18$ & $<0.001$ \\
$10 \mu \mathrm{g}$ poly I:C + DDA & $0 / 6$ & $\mathrm{MS}^{\mathrm{d}}$ \\
$100 \mu \mathrm{g}$ poly I:C + DDA & $0 / 12$ & $\mathrm{NS}^{\mathrm{d}}$ \\
$10 \mu \mathrm{g}$ RNA + DDA & $12 / \mathbb{1 2}$ & $<0.001$ \\
DDA & $1 / 18$ & -
\end{tabular}

a Mice were i.p. injected with poly A:U or poty I:C. Poritive controla meceived RNA from Liateria monocytogenes. Before injection all preparations were combined with $300 \mu \mathrm{Hg}$ DDA. Negative controla received DDA alone. Seven days later all groups were challenged i.p. with 10 LD 50 Listeria monocytogenea. The number of curvivora was detemined 14 days after challenge.

b Number of aumivors/number of mice used.

c $P$ value were calculated relative to DDA controls.

d NS: not oignificont $(P \geq 0.05)$. 
TABLE 2: Induction of protection with single-stranded polyribonucleotides

Treatment of mice survival $^{\mathrm{b}}$ P value

\begin{tabular}{llll}
\hline $100 \mu \mathrm{g}$ poly A:U + DDA & $5 / 6$ & 0.008 \\
$100 \mu \mathrm{g}$ poly $(\mathrm{A}, \mathrm{U})+\mathrm{DDA}$ & $3 / 6$ & $\mathrm{Ns}^{\mathrm{d}}$ \\
$50 \mu \mathrm{g}$ poly A + DDA & $1 / 6$ & $\mathrm{NS}$ \\
$50 \mu \mathrm{g}$ poly U & $+\mathrm{DDA}$ & $3 / 6$ & \\
& DDA & $0 / 6$ & $\mathrm{NS}$
\end{tabular}

a Mice were $i . p$. injected with the aingle atranded polzmibonucleotides poly $(A, U)$, paly $A$, or poly $U$, combined with $300 \mathrm{wg} D D A$. Positive controls recetved poly A:U plus DDA. Negative controls received DDA alone. Seven days latem al. groupe were challenged $i . p$. with 10 LD 50 Listeria monocytogenes. The number of aurvivoms wa datermined it days after challenge.

b number of survivors/number of mice need.

c $P$ valuea were calculated relative to DDA controts.

d NS: not aignificant ( $\geq 0.05)$. 
FIG. 1. Effect of poly (A.U) and poly(I:C) on phagocyte inflammatory responsesi *

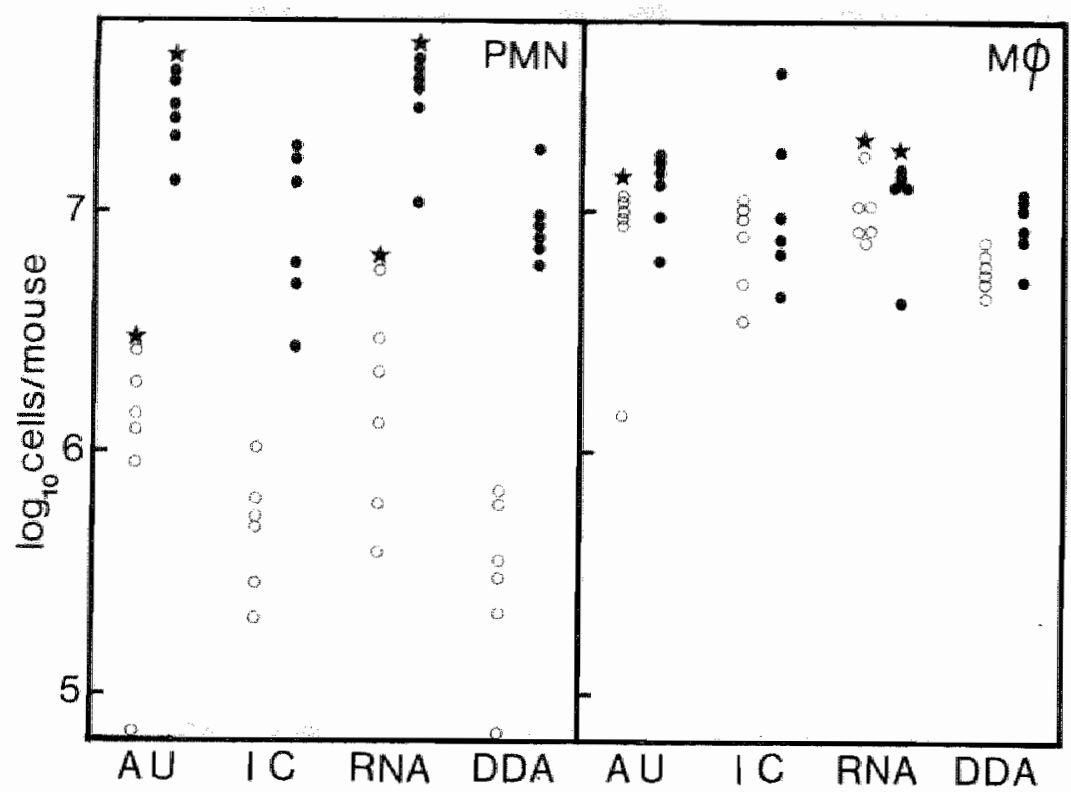

Group of 12 mice were infected $i$.p. with $100 \mathrm{pg}$ poly(A:U) or poly (I:C) and $300 \mu g$ DDA. Controls recetved $10 \mu g$ RNA plus DDA or DDA alone. Sevon days later half of the mise were used to detemine the number of pesident peritaneal macrophages (Mp) and AMNs. The other haif was injeated i.p. with protease peptone and the number of inflamatory BNo and marophages was determined 4 h later. open (ol and atosed (e) sumbol s mepresent celt numbers before and after injection of proteone peptone, nespeatively. (AU: poly (A:U) plus DDA; IC: poly (I:C) plwe DDA; RNA: RNA plue DDA; DDA: DDA; * number of BNe/H oignifiocantly higher than DDA control by Wilocoson's ronk sun teat). 
both groups contalned elevated numbers of resident perltoneal PMNs as compared to DDA controls.

Whereas the injection of proteose peptone induced a massive mobilization of PMNs to the peritoneal cavity, it had only a moderate effect on the number of peritoneal macrophages. Only alce treated with RNA plus DDA contalned a signiflcantly higher number of inflammatory macrophages than mice treated with DDA alone. However, mice treated wth poly A:U plus DDA as well as mice treated with RNA plus DDA contalned a significantly higher number of resident pertitoneal macrophages than DDA controls. The effects of treatment of milce with poly I:C plus DDA were essentially Identical to the effects of DDA alone.

Thus, the synthetic RNA which mimicked the protective properties of Lister1a-RNA (1.e., poly A:U) also had approximately the same effect on phagocyte inflammatory responses as Listerla-RNA. Conversely, the noa-protective poly $I: C$ falled to enhance phagocyte inflammatory responses. Therefore, protection against 11steriosis induced with synthetic RNA plus DDA appeared to be int1mately linked with enhanced phagocyte Inflammatory responses, as previously described with respect to the enhanced resistance against Listeria-infection induced with Listeria-RNA plus DDA (Chapter 6).

\section{DISCUSSION}

Experiments described in this paper findlcate that the enhanced resistance agalngt listerlosis induced with Listerla-kNA could be reproduced with poly A:U. Protection could not be Induced with the random copolymer poly $(A, U)$ or with the double stranded poly $1: C$, Indicating that base composition as well as secondary structura are of relevance wth respect to the mechanism of protection induced with RNA plus DDA.

As RNA is a polyantonic substance, and polyanlons have been reported to protect mice against 1 lsterlosis (Remington and Merigan, 1970) we also tested Listeria-LTA and the synthetic polyantons poly $\mathrm{B}-411$ and poly $\mathrm{R}-478$. However, netther Libteria- 
LTA, nor poly B-411, nor poly $\mathbb{R}-478$ protected mice agalnst listerlosis. Therefore, the chemical and physlcochemical properties which make a particulat substance protective remaln somewhat enigmatic However, at the functional level enhanced inflammatory responsiveness ( $1 \mathrm{n}$ particular of PMNs) appeared to be a common feature of enhanced registance induced with Listerla-RNA plus DDA and protection induced with poly A: U plus DDA. Consequently, further tudy of the effects of poly A:U plus DDA on PMN functions might be useful for the elucldation of the mechanism of protection Induced with RNA plus DDA.

\section{REFERENCES}

Antonlssen, A.C.J.M., Lemmens, P.J.M.R, Gonggr1JP, R., van den Bosch, J.F., and van Boven, C.P.A. (1985) RNase-sensitive and RNase-insensitive protective components Isolated from Listerla monocytogenes. Antonle van Leeuwenhoek 51, 227-240.

Bradley, J.V. (1968) Distribution-free statistical tests. Prentice Hall, Inc., Englewood Cliffs, M.J.

Coley, J., Duckworth, M., and Baddlley, J. (1975) Extraction and purffication of lipotelcholc acids from Grampositive bacterla. Carbohydrate Research 40, 41-52.

Czuprynsk1, C.J., Henson, P.M., and Campbell, P.A. (1984) Killing of Listerla monocytogenes by inflammatory neutrophils and mononuclear phagocytes from imune and nonimune mice. J. Leuk. BLo1. 35, 193-208.

Decker, G.P., Chorpennlng, F.W., and Frederlck, G.T. (1972) Naturally-occurring antibodie to bacillary telcholc acids. J. Immunol. 108, 214-222.

Gonggrijp, R., Mullers, W.J.H.A., Lemmens, P.J.M.R., and van Boven, C.P.A. (1980) Rlbonuclease-sensitive rlbosomal vaccine of Pseudomonas aerug1noma. Infect. Immun. 27, 204-210.

Hagen, J.H., and Hagen, P.B. (1962) An enzymic method for the estimation of glycerol in blood and 1 ts use to determine the effect of noradrenaline on the concentration of glycerol in blood. Can. J. Blochemistry Physiology 40, 1129-1139. 
Herbert, D., Phipps, P.J., and Strange, R.E. (1971) Chemical analysis of microblal cells, p. 209-344. In: J.R. Norris and D.W. Ribbons (eds.), Methods in Microblology vol. 5B Academic Press, London.

Morrison, W.R., and Smith, L.M. (1964) Preparation of fatty acid nethyl esters and dimethylacetals from lipids with boron Eluoride-methano1. I. LIpld Research 5, 601-608.

Remington, J.S., and Merigan, T.C. (1970) Synthetic polyanions protect mice against intracellular bacterlal infection. Nature $226,361-363$.

Rouser, G., Siakotos, A.N., and Fleischer, S. (1966) Quantitative analysis of phospholipids by thin-layer chromatography and phosphorus analysis of spots. Liplds $1,85-86$.

Snyder, F., and Stephens, N. (1959) A simplified spectrophotometric determination of ester groups in 11 pids. Blochimica Blophysica Acta 34, 244-245. 


\section{CHAPTER 8}

PROTECTION AGA INST LISTERIOSIS INDUCED WITH RIBOSOAL RNA PROM LISTERIA MONOCYTOGENES COMBINED WITH THE ADJUVAT DIMETH YLDIOC TA DEC YLAMMONIM BROM TDE (DDA) IS DUE TO A

T-CELL INDE EENDENT MECHANTSM

\section{SUMMARY}

Purified ribosomal RNA from Listerla monocytogenes injected in combination with dimethyldioctadecylammonium bromide (DDA), protects mice nonspecifically agalnst a lethal challenge of various extra- and intracellular bacterla. In the present study we have shown that vaccination of BALB/C as well as C57BL/Ka wice with listerial RNA+DDA resulted into an enhanced In wivo Listeria killing in spleen and liver. Evidence was found that enhanced resistance induced by vaccination with ribosomal RNA+DDA occurred by a T-cel1 independent mechanism: (1) Treatment of mice with Cyclosporin $A$ had no effect on the enhanced Listeria killing Induced with RNA+DDA; (ii) In vitro exposure to RNA+DDA did not Induce 1 ymphocyte prollferation in spleen cell cultures from unvaccinated mice; (11i) Exposure to Ligteria-antigens (formalinkilled Listerla) Induced a massive proliferative responste in spleen cell cultures from mice vaccinated with live Lilsteria, but did not give rise to any lymphocyte proliferation response in spleen cell cultures from tilce vaccinated with RNA+DDA. 
The concept of rtbosomal vacclnes was introduced by Youmans and Youms (26), who showed that RHA-rlch fractions from Mycobacterlum tuberculosis, in comblation with Freund's Incomplete Adjuvant, protected nice agalnst a lethal homologous challenge. The protective activity of this RNA-rlch fraction decreased after treatwent with RNase (27). Since these studles, protective ribosomal vaccins have been prepared from a wide varlety of microorganlsws. In most cases these ribosomal vaccines were more or less contaminated with cell surface components, whereas only in a Iimited number of studies the protective activities were shown to be RNabe sensitive (for revlews see: 7, 10). A few reports showed that ribosomal RNA allso protected mice against heterologous cha1lenge $(1,4,12,16,17)$. The RNase sensitivity of some ribosomal vaccines, as well as the nonspeciflcally increased resistance induced with ribosomal RNA, point at RNA as an Immunomodulating agent.

Recently we reported that highly purifled ribosomal RNA from Listeria monocytogenes protected BALB/c mice against homologous and heterologous challenge, provided that the RNA was injected in combination with the adjuvant dimethyldioctadecylamonium bromide (DDA) (1). Vaccination with RNA or DDA alone was ineffective. Intraperitoneal waccination w1th RNA+DDA protected $92-100 \%$ of mice agalnat Intraperttoneal challenge with L. monocytogenes. Subcutaneous vecciation was less effective but still induced $58 \%$ protection. Therefore, protection Induced with RNA+DDA appeared to be at least partially due to systemic effects. In this study the systemic protection Induced with RNA+DDA is analyzed by subcutaneous vaccination of mice and intravenous challenge with $\underline{L}$. monocytogenes. It is shown that vaccination with RNA+DDA induced an accelerated elimination of Listeria from spleen and Ilver. Furthemore, evidence from several in vivo and in vitro experiments lead us to conclude that protection induced with RNA+DDA was due to a $\mathrm{T}$-cell independent mechanism. 
MATERTALS AND METHODS

Bacterial strain.

L. monocytogenes strain L242, serotype 4 b was used for puriflcation of RNA as well as for animal experiments. Virulence was increased by repeated mouse passage. Bacteria were cultured in medlum as described previously (2). For stock suspensions, overnight grown Listerla were supplemented with $15 \%$ glycerol, and aliquots of 1 mil containing $2 \times 10^{9} \mathrm{CFU} / \mathrm{m} 1$ were stored at $-70^{\circ} \mathrm{C}$. The Listeria stock suspensions were used immedlately after thawing. and dilution to the appropriate concentration in phosphate buffered saline, $\mathrm{pH} 7.2$ (PBS). The same batch of Listerta was used for all antmal experiments, with a $50 \%$ lethal dose after intravenous (i.v.) injection of approx. $1 \times 10^{4} \mathrm{CFU}$ for $\mathrm{BALB} / \mathrm{c}$ mice.

Animals.

Malle BALB/c mice were purchased from TNO, Zelat, The Netherlands, and used at an age of $7-8$ weeks. Female c57BL/Ka nude (nu/nu) mice, and their immunologically normal controls, heterozygous for the mutation nude $(\mathrm{nu} / \mathrm{t})$, were purchased from TNo, Rijswijk, and used at an age of $7-8$ weeks. Nude mice and thelr controls were held In a separate 1 solated room; cages, bedding and food were autoclaved before use and cages were covered with sterile filter caps or kept in a laminar flow cablnet.

Purtelcation of RMA.

RMA was extracted from purtifled ribosomes as described previously $(1,11,12)$. The purdfled RNA contalned 1es than $1 \%$ proteIn. RNage treatment of RNA was carried out as described ( 1 ).

Antmal experiments.

Mice were Injected $1 . \mathrm{v}$. with a sublethal dose of L. monocytogenes in $0.5 \mathrm{ml}$ and the $1 \mathrm{~m}$ vivo killing or growth lahib1tion of Listeria was measured by determination of the CFU in spleen and liver. At varlous time intervals upto 3 days after challenge wice were killed wth ether. Spleens and Ilver were 
removed aseptcally and homogenized separately in a total volume of 5 ml of distilled water in a tisaue grinder. Sertal 10-fold dilutions were plated out in duplicate on Trypticase Soy Agar (BBL, Cockeysv11le, MD). The mean CFU per organ was calculated for at leat 5 wice, from experiments carried out in at least 2 different weeks *

For vaccination experimenti, mice were injected subcutaneously (s.c.) 7 days before challenge ith $0.1 \mathrm{ml}$ of PBS containing elther $10^{5}$ Listerla, or $100 \mu 8$ RNA plus $300 \mu g$ DDA (Eastman Kodak Co., Rachester, N.Y.), $100 \mu \mathrm{g}$ RNA, or $300 \mu \mathrm{g}$ DDA. DDA wasi sonicated briefly before use. Injection of $0.1 \mathrm{ml}$ PBS served as a control.

\section{Cyclosporin A.}

Cyclosporin A (CyA; kindly provided by Sandaz, Basel, Switzerland) was dissolved in a concentration of $20 \mathrm{mg} / \mathrm{ml}$ in olive o11 at $65^{\circ} \mathrm{C}$. In anlmal experiments, $20 \mathrm{pl}$ per mouse $(20 \mathrm{mg} / \mathrm{kg})$ was Injected intraperftometly (1.p.) on each day during the exper1ment, including the vacelnation and the challenge perlod, starting one day before vaccination.

\section{Lymphocyte proliferation assay.}

Spleen cells from BALB/c mlce were prepared as usual, and seeded into microtiter plates at a density of $5 \times 10^{6} \mathrm{cells} / \mathrm{m} 1 \mathrm{in}$ 0.2 ml Dulbecco Minimal Essential Medium supplemented with $10 \%$ heat-Inactivated fetal calf serum, $100 \mathrm{U} / \mathrm{ml}$ penictilin and 100 ug/ml streptomycin. The cells were incubated in the presence of varlous concentrations RNA and DDA for $72 \mathrm{~h}$ at $37^{\circ} \mathrm{C}$ in a humidified atmosphere of $7 \% \mathrm{CO}_{2}$ in alr. During the last 4 h of the Incubation $0.5 \mathrm{uCl}\left[{ }^{3} \mathrm{H}\right]$ thymidine (specific activity $2 \mathrm{Ci} /$ mol $)$ was added. The cells were harvested with a mleroharvester and $\left[{ }^{3} H\right]$ thymidine uptake was measured In liquid scintillation counter. As controls were 1 included incubation of spleen cells with elther $2.5 \mathrm{\mu g} / \mathrm{ml}$ concanavalin A (ConA) or $10^{7} / \mathrm{ml}$ formalin-killed Listeria (FKLM). Spleen cells were used from untreated mice and from mice vaccinated with RNA+DDA or live Listeria. The results are presented as 
the means of separate assays on cells from four lndividual mice.

Statistical evaluation.

The data were analyzed for significant differences by the Two Sample $t$ Test.

RESULTS

Influence of vaccination on the fate of Listeria in liver and spleen:

BALB/c milce were injected s.c. With the varlous preparations, and 7 days later challenged $1 . v$. With Listeria. The kinetics of Listerla in liver and spleen were followed up to 3 days after challenge. As shown in FIg. 1 (liver) and FIg. 2 (spleen), pretreatment of the mice with RNA or DDA alone had no effect on the viable counts of Listeria as compared with control mice pretreated with PBS. However, vacelnation with the combination of RNA+DDA resulted $1 \mathrm{n}$ an enhanced in vivo killing of Listeria in both liver and spleen. In the liver the Listeria counts in mice vaccinated with RNA+DDA were significantly lower compared with mice vaceinated ith DDA alone, at $48 \mathrm{~h}(\mathrm{P}=0.0001)$ as we 11 as $72 \mathrm{~h}$ $(\mathbb{P}=0.0006)$ after challenge. Also the spleen counts in RNA+DDA-mice were significantly lower than in DDA-mice, both at $48 \mathrm{~h}(\mathrm{P}<0.0001)$ and $72 \mathrm{~h}(\mathrm{P}=0.013)$ after challenge.

This enhanced $1 \mathrm{n}$ vivo $\mathrm{k} 1111 \mathrm{ng}$ induced by vaccination with RNA HDDA was abollshed after RNase treatment of the RNA. RNaige treatment of RNA prior to vaceination with RNA+DDA resulted 72 $h$ after challenge in a log. C.F.U. of $5.42+0.24$ and $5.90+0.28$ in liver and spleen respectively, both not signiflcantly different from the Listerla counts in mice pretreated with DDA alone. As expected, vaccination with live Listeria resulted in a very eff 1 cient killing of Listerla, espectally in the spleen.

\section{Effect of $\mathrm{T}$-cell deficiency on vacclnation.}

To Investigate the contribution of $\mathrm{T}-1$ ymphocytes to the enhanced in vivo killing of Listerla Induced with RNA+DDA vaccination 


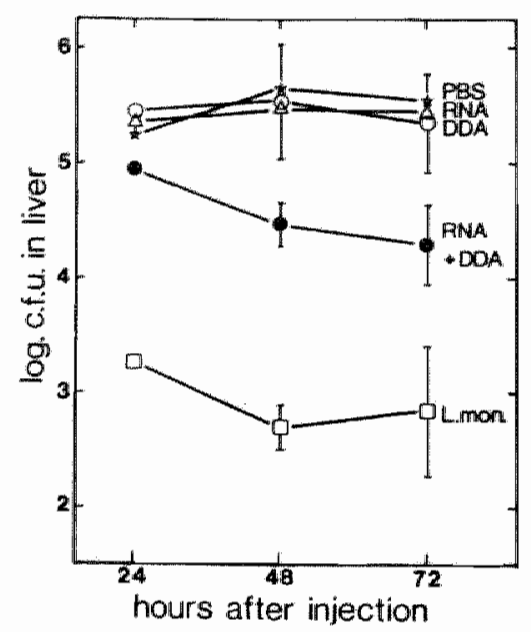

EIG. 1. Fate of L. monocytogenes in livers of mice aftsr $i . v$. infeation $(20 g$. dose $=3.74 \pm 0.03)$. Seven days before challenge the mice were vacuinated B.c. with live Libteria (L. mon.), ribosomal RNA+DDA, RNA or DDA alone, or with PBS (control 6 ). Vertical bars indicate the $S D$ values. 


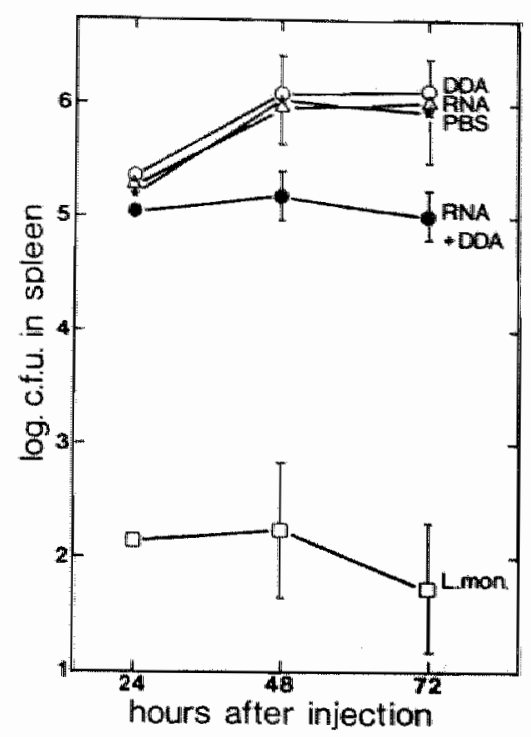

FIG. 2. Pate of L. monocytogenea in spleens of mice after $i . v$. infection $(\mathrm{log}$. dose $=3.74 \pm 0.03)$. Sever daye before challenge the nice were vaccinated a.c. With live Ligteria (L. mon.), ribosomal RNA+DDA, RNA ar DDA alone, or with PBS (controt $B$ ). Vertical bara indicate the SD values. 
experifents were carried out in two $\mathrm{T}$-cell deflcient animal models. Firsty, T-cells were suppressed by treating mice ith CyA, an lahibitor of $\mathrm{T}$-cell functions. Secondly, athymic mude alce lackling $T$ lymphocytes were used. BALB/c mlice were treated $i \cdot p$. with CyA, wacelated $s . c$. and 7 days later challenged 1 .w. with Listerla. Three days after challenge the numbers of viable Listerla in spleen and liver were determined. Since CyA was disgolved in ollve all, control mice recelved also ollve oll $1 . p$. As shown in Table 1, CyA treatment of the nuce had no effect on the enhanced in vivo killing of Listerla induced with RNA+DDA. In contrast, the enhanced In vivo k1111ng 1nduced by vaccination with live Listerla was abollshed completely when the mice were treated with CyA.

Athymic nude C57BL/Ka mice and thelr phenotypically normal controls were vacelnated s. $c$, challenged $1 . v .7$ days later, and 3 days after challenge the viable count in spleen and liver was determined. As shown in Table 2, the enhanced $1 \mathrm{n}$ vivo killing Induced in control (nu/t) mlce by vaccination with both live Listerta as well as RMA+DDA, was in both cases no longer observed in nude (nu/nu) mice.

\section{Lymphocyte proliferation in witro.}

The posistble effect of RNA and DDA on $T$ lymphocytes was also tested In two ln vitro proliferation assays. Firstiy, spleen lymphocytes from normal mlce were incubated with RNAHDA (Table 3). For positive controls, lymphocytes were treated in vitro with ConA. As expected, exposure of 1 ymphocytes to ConA resulted Into a marked proliferative response. In contrast, RNA+DDA failed to Induce lymphocyte proliferation in the concentrations tested $(1,5$ and $10 \mu \mathrm{g} /$ mi). The concentrations RNA and DDA used did not affect cell viability as judged by trypan blue excluston.

Secondly, to find out whether vaccination with RNA+DDA primed 1 ymphocytes for a proliferative response to Listeria-antigens, spleen cells from vaccinated mice were incubated wh FKLM (Table 4). Vacclnation wth live Listeria was used as a positive control. As expected, vaccination of mice with live Listeria resulted into 
TABLE 1: Effect of Cyclosporin A (CYA) on the viable counts in spleen and Liver of ince 3 days after $1 . \%$. Mjection of Llsteria $(\log \cdot \mathrm{dose}=3.27+0.13)$

Organ and Vaccination ${ }^{\mathrm{c}}$ of mice wth

treatment

of mice ${ }^{b}$ PBS RNA+DDA L. monocytogenes

\section{Liver:}

$\begin{array}{lllll}\text { Olive oil } 5.62 \pm 0.36 & 4.15 \pm 0.52 \quad(\mathrm{P}=0.001) & 2.98 \pm 0.42 \quad(\mathrm{P}<0.0001) \\ \text { CyA } & 5.68 \pm 0.20 & 4.52 \pm 0.27 \quad(\underline{P}=0.0001) & 6.55 \pm 0.33 \quad(\underline{P}=0.003)\end{array}$

Spleen:

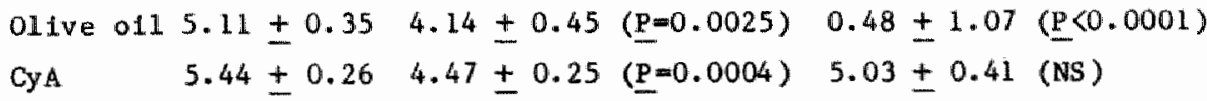

a The figurea repreaent the mean $\mathrm{log}$. C.E.U. + S.D. The $P$ valuea were calculated campared with PBS controls; NS, not oignificant.

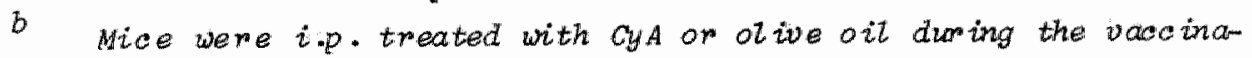
tion and the challenge period.

- Mice were vaccinated a.c. With live L. monocytogenes, RWA ADA, or PBS seven days before chatzenge. 
TABE 2: The vilable counts 40 spleen and liver of athymic nude (nu/mu) mice and their immunologically normal controls $(\mathrm{nu} / \mathrm{t}), 3$ days after 1.v. Injection of Listeria (log. dose $=$ $3.79+0.18)$

\begin{tabular}{|c|c|c|c|}
\hline \multirow{2}{*}{$\begin{array}{l}\text { Organ and } \\
\text { type of } \\
\text { mice }\end{array}$} & \multicolumn{3}{|c|}{ Vaccination of mice with } \\
\hline & PBS & $\mathrm{RNA}+\mathrm{DDA}$ & L. monocytagenes \\
\hline \multicolumn{4}{|l|}{ Liver: } \\
\hline $\mathrm{nu} / \mathrm{t}$ & $4.99+0.41$ & $3.51 \pm 0.34 \quad(\mathrm{P}=0.001)$ & $1.21 \pm 0.48(\underline{\mathrm{P}}<0.0001)$ \\
\hline nu/nu & $4.64+0.56$ & $4.54+0.39$ (NS) & $4.85+0.32(\mathrm{NS})$ \\
\hline
\end{tabular}

Spleen:

$\begin{array}{llll}\mathrm{nu} / \mathrm{t} & 5.52 \pm 0.26 & 4.10 \pm 0.41 \quad(\mathrm{P}=0.0008) & 1.43 \pm 0.22(\mathrm{P}<0.0001) \\ \mathrm{nu} / \mathrm{nu} & 4.65 \pm 0.50 & 4.48 \pm 0.43 \text { (NS) } & 4.36 \pm 0.52 \text { (NS) }\end{array}$

a The figures represent the mean $20 g . G . F . U . \pm S . D$. The $P$ val wes ware calculated compared with EBS controls; NS, not aignificant.

b Mice were vace inated a.c. With 2 ive $L$. monocytogenes, RNA+DDA, or PBS seven days before challenge. 
an increased proliferative response to FKLM compared with unvace1nated controls. Vaccination with RMADDA did not result into an increased response to FKLM.

\section{DISCUSSION}

In the present study we have shown that s.c. Injection of purifled ribosomal RNA in comblnation with the adjuvant DDA enhanced the in vivo killing of Listerla in liver and spleen after an $i . W$. challenge with a sublethal dose of Listerla. Since resistance against intracellular microorganisms like L. monocytogenes is generally believed to be mediated by activated nacrophages with an enhanced bactericidal capacity (for review see: 13), our results strongly suggest that RNA+DDA activates macrophages. This is supported by previous findings that RNA purifled from $L$. monocytogenes or $P$. aeruginosa injected together with DDA protected mice also nonspectflcally against a lethal dose of heterologous bacteria $(1,12)$, and 1 t 1 senerally accepted that macrophages once activated exert their bacterlcidal activities nonspecifically.

Inmunologically normal BALB/c as well as C57BL/Ka mice showed the enhanced in vivo Listeria killing lnduced with RNA+DDA. This seems to be in conflict with the results of Medina et al. (16), who reported that only mice inherently resistant to L. monocytogenes $(C 57 \mathrm{BL} / 6 \mathrm{~J})$ and not inherently sensitive tolce $(\mathrm{A} / \mathrm{J})$ could be protected agalnst Listerla challenge by Imunization with Llaterla RNA. Since BALB/c mice are Inherently sensitive to Llsteria (5), our results Indicate that also in Llsterla bensitive mice macrophage activation can be induced with Listeria RNA, provided that this RNA is adminlatered in combliation wh DDA.

T-cell mediated immunity plays major role in protection against 1isteriosis in mice. In Listerla-imune mice sensitized $T$ lymphocytes act upon contact with Listeria antigen by releasing 1 ymphokines that activate macrophages to $k 111$ the bacterla (13, 14). Recently the lymphokine interferon- $\gamma$ has been identified as the macrophage activating factor $(9,18,23)$. Cyclosporin A (CyA), 
TABLE 3: Lymphocyte prollferation after in vitro exposure of spleen cells from untreated mice

\begin{tabular}{|c|c|c|}
\hline$\frac{\text { In vitro exposure }}{\text { with }}$ & $\begin{array}{l}\left({ }^{3} \mathrm{H}\right) \text { Thymid lne uptake } \\
(\mathrm{cpm} \pm \mathrm{SD})\end{array}$ & P value \\
\hline- & $4,106 \pm 944$ & - \\
\hline RNA + DDA $(1 \mu g / m 1)$ & $4,813 \pm 3,137$ & $\mathbb{N} \cdot 5 \cdot{ }^{a}$ \\
\hline $\mathrm{RMA}+\mathrm{DDA}\left(5 \mathrm{plg}^{\mathrm{m}} \mathrm{mL}\right)$ & $2,558 \pm 397$ & N.S. \\
\hline $\mathrm{RMA}+\mathrm{DDA}(10 \mu \mathrm{g} / \mathrm{mL})$ & $3,101 \pm 762$ & N.S. \\
\hline $\operatorname{ConA}(2.5 \mu g / m 1)$ & $79,086 \pm 7,991$ & $<0.0001$ \\
\hline
\end{tabular}

TABLE 4: Lymphocyte proliferation after in vitro exposure of spleen cells from vaccinated mice

\begin{tabular}{llcl}
\hline Vaccination & In vitro exposure & $\begin{array}{l}{\left[^{3} \text { H }\right] \text { Thymidine uptake }} \\
(\text { cpm } \pm \text { SD })\end{array}$ & $\underline{\text { p value }}$ \\
\hline with & FKLM & \\
LLsterla & FKLM & $6,780 \pm 141$ & - \\
RNA+DDA & FKLM & $18,563 \pm 1,931$ & $<0.0001$ \\
& & $5,591 \pm 1,558$ & N.S.
\end{tabular}

a Vacination b. with tive Listeria on RNA+DDA 7 daye before splean oelt harvesting.

b PKLM, fomal in-killed Listeria. 
a specific inhlbitor of T-cell functions $(22,25)$, has been found to inhibit lynphokine production including interferon- $y(15,21$, 24). In the present study it was shown that CyA Indeed Inhibited the in vivo macrophage activation induced by vaccination with live Listeria. In contrast, treatment of mice with CyA did not inhiblt the enhanced $\mathbb{t n}$ wivo killing of Listerla induced with RNA+DDA. Therefore it is concluded that macrophage activation induced by vaccination with RNA+DDA was most likely not mediated by $T$ iymphocytes. This concluston is supported by the results of the 1 in vitro lymphocyte proliferation experiments. As expected, lymphocyte proliferation was observed when spleen cells from untreated mice were cultured 1 n the presence of ConA. Enhanced 1ymphocyte proliferation was also observed after exposure of FKLM to spleen cells from Listeria-immune mice. However, lymphocyte proliferation was seen neither after in vitro exposure of norwal spleen cells to RNAHDDA, nor after exposure of spleen cells from RNA+DDA vaccinated mice to FKLM.

Seemingly conflicting results were obtallned in the experiments with athymic nude mice, since enhanced in vivo killing of Listeria induced by vaccination with RNA $+D D A$ was not observed in nude mice. If macrophage activation by RNA+DDA is supposed to be mediated by a $\mathrm{T}$-cel1-independent mechantsm, one would expect macrophage act $1-$ vation to accur in athymic mice as well. However, several studies have show that nude mice are more resistant to 11 sterlosis in the intial phase of infection than normal inlee, because of the presence of more highly activated flxed tissue macrophages $(6,8,19$, 20,28 ), and $1 \mathrm{t}$ might be possible that macrophages once activated cannot become more activated by RNA+DDA.

Alternatively, the ineffectiveness of RNA+DDA in nude mice might be due to defects other than the we 11-documented $T$-cell deficiency. Recently, indications were found that the initial phase of the expression of protection against 11sterlosid induced with RNA+DDA is due to activated polymorphonuclear leukocytes (PMNS) rather than to actlvated macrophages (3).

Therefore, the Ineffectiveness of RNA+DDA In nude mice might also be related to anomalous PMN functions, efther because nude mice 
contaln PMN which are already activated, or because RMA+DDA does not induce Rill-activation in nude mice.

\section{LITERATURE CITED}

1. Antonlssen, A.C.J.H., P.J.M.R. Lemmens, R. Conggrijp, J.F. van den Bosch, and C.P.A. van Boven. 1985. RNase-sensitlve and RWase-Insensitive protective components lisolated from Lister1a monocytogenes. Antonle van Leeuwenhoek 51:227-240.

2. Antonlissen, A.C.J.M., K.P.M. van Kesse1, H. van D1jk, and J.M.N. Willers. 1981. Development of a simple passive haemaggiutination-1nhibition assay for Listeria monocytogenes. J. Imunoll. Meth. 44:351-357.

3. Antonlssen, A.C.J.M., P.J.M.R. Lemmens, J.F. van den Bosch, and C.P.A. van Boven. 1987. Transfer of enhanced resistance agatnst Listeria monocytogenes induced with ribosomal RNA and the adjuvant dimethyld loctadecylamonium bromide. Immonology Letters 14 (1) (In press).

4. Araujo, F.G., and J.S. Remington. 1974. Protection against Toxoplasma gondil in mice immuntzed with toxoplasma cell fractions, RNA and synthetic polyriboutcleotides. Immunol. $27: 711-721$.

5. Cheers, C., I.F.C. Mckenzile, H. Pavlov, C. Wald, and J. York. 1978. Resistance and susceptibility of mice to bacterlal Infection: cour of of 1 isteriosis 1 in resistant and susceptible mice. Infect. Immun. 19:763-770.

6. Cheers, $C^{.}$, and $\mathrm{k}$. Waller. 1975. Activated macrophages in congeaitally athymic "nude" mice and in lethally irradiated milce. J. Immunol. 115:844-847.

7. Eisenstein, T.K., C.R. Angerman, and L.W. Deakims. 1981. Ribosomal wacines as immunomodulators, p. 199-214. In H* Friedman, T.W. Kleln and A. Szentivanyt (ed.), Immunomodulation by bacteria and their products. Plenum Press. New York. 
8. Ermerling, P., H. Finger, and H. Hof. 1977. Cel1-medhated resistance to finfection with Listerla monocytogenes in nude nice. Infect. Immun. 15:3:82-385.

9. Fukazawa, Y., K. Kagaya, H. Miura, T. Shinoda, K. Natori, and S. Pamazaki. 1984. Blological and blochemlcal characterization of macrophage activating factor (MAF) in murine 1ymphocytes: physicochemical similaricy of MAF to gamma interferon (IFM-y). Microbiol. Immunol. 28:691-702.

10. Gonggrijp, R., A.C.J.M. Antonissen, J.F. van den Bosch, and C.P.A. van Boven. 1984. Ribonuclease-sensitive ribosomal vaccines. Antonle van Leeuwenhoek 50:763-774.

11. Gonggrijp, R., W.J.H.A. Mullers, P.J.M.R. Lemmens, and C.P.A. van Boven. 1980. Ribonuclease-sensitlve ribosomal vaccine of Ps eudomonas aerug 1nosa. Infect. Immun. 27:204-210.

12. Gonggrijp, R., W.J.H.A. Mullers, and C.P.A. van Boven. 1981. Serotype-nonspecific protection induced by ribonucleic acid lsolated from the ribosomal vaccine of Pseudomonas aerug Inosa. Infect. Immun. 33:178-185.

13. Hahn, H., and S.H.E. Kaufmann. 1981. The role of cel1mediated immunity in bacterial infectlons. Rev. Infect. Dis. 3: $1221-1250$.

14. Hahn, H., and S.H.E. Kaufman. 1982. T 1ymphocyte-macrophage interactions in cellular antibacterial 1mmunity. Immunoblol. 161: $361-368$.

15. Kalman V.K., and G.R. Klimpe1. 1983. Cyclosporin A InhibLta the production of gama incerferon (IFN), but does not inhlibit production of virus-1nduced IFN $\alpha / B$. Ce11. Immunol. $78: 122-179$.

16. Medina, S., S.I. Vas, and H.G. Kobson. 1975. Effect of nonspeciflc stimulation on the defense mechanlaws of lnbred mice. J. Immunol. 114:1720-1725.

17. MLfeldt, M.L., and W. Johnson. 1978. Protective ability of Salmonella ribosomal protein and RNA in inbred mice. Infect. Imon . $21: 286-291$. 
18. Wathan, C.F., H.W. Murray, M.E. Wlebe, and B.Y. Rubin. 1983. Identiflcation of interferon- $p$ as the lymphokine that activates human macrophage oxidative metabolism and antimicroblal activ1ty. J. Exp. Med. 158; 670-689.

19. Newborg, M.F., and R.J. North. 1980. On the mechanism of T cell-independent anti-Listeria resistance in mude mice. J. Iminumol. 124: $571-576$.

20. N1cko1, A.D., and P.F. Bonventre. 1977. Anomalous high mative resistance of athymic mice to bacterial pathogens. Infect. Immun. $18: 636-645$.

21. Reem, G.H., L.A. Cook, and J. Vilcek. 1983. Gamma interferon synthesia by human thymocytes and $\mathrm{T}$ lymphocytes 1nhlbited by cyclosporin A. Sclence 221:63-65.

22. Schaffner, A., H. Douglas, and C.E. Davls. 1983. Models of T cell deficiency in $\mathbb{1}$ isteriasis: The effects of cortisone and cyclosporin $A$ in normal and nude BALB/c mice. J. Immunol. $131: 450-453$.

23. Svedersky, L.P., C.V. Benton, W.H. Berger, E. Rinderknecht, R.N. Harkins, and M.A. Palladino. 1984. Blologlcal and antigenic similarities of murine interferon- $\gamma$ and macrophageactivating factor. J. Exp. Med. 159:812-827.

24. Thomsion, A.W., D. K. Moon, and D.S. Ne 1son. 1983. Suppression of delayed-type hypersensitivity reactions and lymphokine production by cyclosporin A In the mouse. Clin. Exp. Immunol. 52: 599-606.

25. Wellsinger, D., and J.F. Bore1. 1979. Studles on the mechanism off action of cyclosporin A. Imunoblo1. 156:454-463.

26. Youmans, A.S., and G.P. Youmans. 1965. Immunogenic activity of ribosomal fraction obtained Erom Mycobacterium tuberculogis. J. Bacter101. 89:1291-1298.

27. Youmans, A.S., and G.P. Youmans " 1966. Effect of trypsin and ribonuclease on the immunogenic actlvity of ribosomes and ribonucleic acld lsolated from Mycobacterlum tuberculosis. J. Bacter101. 91:2146-2154. 
28. Zinkernagel R.M., and R.V. Blanden. 1975. Macrophage activation in mice lacking thymus-dertved (T) cells. Experientia $31: 591-593$. 


\section{CHAPRER 9}

\section{SLMMARY AND GENERAL DISCUSSTON}

Subject of this thesis is the modulation of antibacterial resistance by subcellular preparations from Listeria monocytogenes (L. monocytogenes). A crude $r$ ibosomal preparation from $L_{\text {. mono- }}$ cytogenes L 242 , serotype $4 b$ was separated 1 nto cell envelope fragments (fraction I) and purified ribosomes (fraction II) by molecular sieve chromatography. In combination with the adjuwant dimethyldioctadecylammonium bromide (DDA) both preparations protected mice against lethal infection with L. monocytogenes. Preparations without DDA or DDA alone did not induce protection. Ribosomal RNA was identffied as the major protective component of fraction II, as the protective properties of this fraction were destroyed by RNase-treatment but not by treatment with proteinase K. Furthermore, also purifled rRNA extracted from fraction II protected mice against listerlosis. The protective properties of fraction I were not affected by RNase-treatment, proteinase $K$ treatment, or sequential treatment with both enzymes. Fraction I plus DDA as well as RNA plus DDA also protected mice against L. monocytogenes serotype 3, Pseudomonas deruginosa and Streptococcus pneuronlae.

As immuntty to listeriosis is frequently assoctated with a state of delayed-hypersensitivity (DH) to Listeria-antigens, we also investigated whether DH could be induced or ellcited with fraction I or RNA. Fraction I plus DDA induced DH to killed Listeria. Conversely, DH induced by Immantation with viable Listeria could be eliclted with fraction I. However, DH could not be induced or ellcited with RWA. Protelnase K-treatment of fraction I destroyed 1 ts ability to induce DH against k1lled Liateria. Therefore DH induced with fraction I was apparently due to proteinase $K$-sensitive protelns, whereas enhanced resistance induced with this preparation was due to non-proteln components or 
to proteinase K-reslstant peptides/protelns. Experiments with protein fractions isolated from fraction $I$ suggested that several protelns contributed ta the induction of DH with fraction I. However, DH could also be Induced with a siggle purtifled protein (TW 20,400).

As attempts to identify the chemlcal aature of the protective components of fraction I were inconclusive, further experiments were reaticicted to eluclidation of the mechanlsm of protection Induced wth RW plus DDA. In addition to Listerla rRMA also heterologous rRNA (from P. aeruginosa) and the synthetic RNA poly A:U protected mice agalnst 11steriosis. These observations ouggested that the mechanism of protection induced with RNA plus DDA might be different from the mechanlism of protection induced by Immunization with viable Listerla which depends on recognition of Listeria-antigens by Listerla-specific T-cells *

The immunosuppreselve drug cyclosporin $A$, which inhibits the Induction of $\mathrm{T}$-cell-dependent 1mmity with viable Listeria, did not affect the Induction of protection with RNA plus DDA. Therefore, enhanced reststance Induced with RMA plus DDA was apparently due to a $\mathrm{T}$-cel1-independent modulation of phagocyte functions.

Upon Intraperitoneal injection of the sterile 1rritant proteose peptone, mice treated seven days previously with RNA Plus DDA were found to mobll1ze Increased numbers of polymorphonuclear leukocytes (PMNs) and macrophages to the inflamed peritoneal cavity as compared to mice treated with DDA alone. Also protection to $11 \mathrm{~s}^{-}$ terlosis induced with poly A:U plus DDA was found to be assoclated wth enhanced phagocyte inflamatory responsiveness. Enhanced resistance induced 1 th RNA plus DDA could be transferred to normal rectplent mice with inflanatory macrophages (collected 48 $\mathrm{h}$ after the injection of proteose peptone) as we 11 as with $4 \mathrm{~h}$ Inflammatory PMNs. Inflamatory PMNs as well as inflammatory macrophages from mice treated with RNA plus DDA appeared to be activated, recipient mice could not be protected against 11ster1osis with inflammatory PMNs or macrophages from mice treated with DDA alone.

Whereas protection to Listeria monocytogenes induced by immu- 
nization with viable Listerla depends on T-cell mediated macrophage activation, RNA plus DDA protected mice against 1isterlosis through a T-cell-independent mechanism which was patilly basied on activation of PMNs, cells which are generally considered to be only of minor importance for the elimination of intracellular parasites such as Listerla monocytogenes* 
Listerla monocytogenes is een bacterie die na het blnnendringen van het lichaam snel wordt opgenomen door macrofagen. Terwijl vele micro-organisnen na opname door macrofagen door deze cellen worden gedood, is Listeria monocytogenes in staat binnen macrofagen te overleven en zich intracellulair te vermeniguuldigen. Dit proces leldt veelal tot de dood van de macrofaag, warna de lnfectle zlch verder door het lichaam kan verspreiden. Infecties die niet $t \mathbf{f j d g}$ tot staan worden gebracht, leiden tot de dood of tot restverschijnselen dle voornamelfjk van neurologlsche aard zijn. Bij de bestrijding van Listeria-infectles kunnen zowel het afweersysteem van de gastheer als antibiotica-therapie een rol spelen.

Uit onderzoekingen van Mackaness is gebleken dat proefdieren tegen een dadelijke infectle met Listerla monocytogenes kunnen worden beschermd door immunisatie met eem niet-dodelljke dosls levende bacterién. In tegenstelling tot macrofagen gelisoleerd uit nlet-gelmmuniseerde dieren bleken macrofagen ult gelmantseerde dieren wèl in staat te zijn Listeria te doden. Dit verschljnoel wordt aangeduld met de term "macrofaag-activering" . De bescheming. tegen Listerla monocytogenes geinduceerd door immunisatie met levende bacterién kan op niet-gelmunlseerde dieren worden overgedragen met behulp van miltcellen gelsoleerd ult gelmmunimeerde dieren. Blj nadere analyse bleek de overdracht van bescheruing door miltcellen te berusten op in de allt aanwezige T-cellen. Door contact met macrofagen die Listerta-bacteriën hebben opgenomen, worden deze $T$-cellen aangezet tot het witschelden van factoren (1ymfokinen) die de antibacteriele elgenschappen van macrofagen dusdanig kunnen versterken dat deze cellen wel in btat zijn om Listeria te doden. De interactie tussen $\mathrm{T}$-cellen ult tegen Listeria geimmuniseerde proefdieren (ListerLa-immun $T$-cellen) en met inacrofagen geassocieerde Listeria-antigenen 18 speciflek, dat w1 zeggen lymfokine-produkt le en macrofaag-activering treden niet 
op Indien an Listerla-1muun $\mathrm{T}$-cellen andere bacterlële antigenen worden alageboden. Eemaal geactiveerde macrofagen zijn echter in staat om nast $\mathrm{L}$. monocytogenes pok andete intracellulaire bactertên te doden. Len karakterlotiek kenmerk van de afweer tegen $\underline{L}$. monocytogenes is, dat immultelt nlet kan worden opgewekt met behulp van dode bacterièn tenzlj het dode vaccin wordt gecomblneerd met adjuvantla zoals het dimethyldioctadecylamonium bromide (DDA). Terwl1 het mechanlsme van de bescheming geinduceerd door immunisatie met Levende bacterien gratendeels is opgehelderd, is betrekkelljk welnig bekend met betrekking tot het mechanlsme vam de bescherming getnduceerd door dode Listerla-vaccins in combinatle wet adjuvantia.

Onderwerp van dit proefschrift is het mechanisme van de bescherming geinduceerd door subcellulalre vaccins gelsoleerd ult Listerla monocytogenes. Een ruw ribosomal preparaat gelsoleerd ult $L$. monocytogenes L242, seratype 4 b, werd met behulp var ge1filtratle geschelden in cel-envelop fragmenten (fractie $I$ ) en gezulverde ribosomen (fractle II). Door Imunisatie met fractie I of fractie II in combinatie met het adjuvans DDA kon in BALB/C mulzen bescherming tegen een dodelijke lafectle met Listeria monocytogenes worden opgewekt. Bescherming kon niet worden geInduceerd met fractie I of fractle II zonder DDA, of met DDA alleen. Ribosomal RNA werd geldentificeerd als de belangrijkste beschermende component in fractle $\mathbb{I I}$, ondat de beschermende activltelt van deze fractie werd vernletigd door behandeling met RNase, war niet door behandeling met een efwt-splitaend enzya (protelnase $k$ ). Bovendten kon bescherming ook gelnduceerd worden met gezulverd ribosomal RNA, gelsoleerd uit fractie II. De beschermende activitelt van fractle I werd niet angetast door behandeling met RNase of protelnase $K$, of door behandeling met RNa se gevolgd door behandeling met protelnase $\mathbb{K}$. Behandeling van mulzen tret fractie I plus DDA of RNA plus DDA Induceerde niet alleen bescherming tegen $L$. monocytogenes serotype $4 \mathrm{~b}$, maar ook tegen L. monocytogenes serotype 3 , Streptococcus pneumonlae en Pseudononas aerug Inosa. 
Aangezlen immunitelt tegen listeriose valk gepard gaat met een toestand van vertraagd-type overgevoeligheld (VTO) tegen Listeria-antigenen (te vergelljken met de Mantoux-reactie zoals gebruikt bij de controle op TBC-besmetting) werd ook onderzocht of VTO geinduceerd of opgewekt kon worden met fractle I of $\mathbb{R} N A$. Fractie I plus DDA induceerde VTo tegen dode Listeria. Bovendien kon VTO geinduceerd door Immunisatie met levende Listerla opgewekt worden met fractie I. Een VTO-reactie kon echter niet opgewekt of gelinduceerd worden met RNA. De VTO-inducerende elgenschappen van fractie I werden vernietigd door proteinase K-behandeling. Proteinase $K$-gevoelige elwitten waren derhalve verantwoordelijk woor de inductie van VTO met fractie $I$, terwijl de bescherming $\mathrm{ge}^{-}$ Induceerd door fractie I klaarblijkelijk gebaseerd was op andere componenten dan eiwtten, of op eiwlten of eiwftragmenten die ongevoelig waren voor proteluase $k$. Uit vTo-experlmenten met eiwitfracties gelsoleerd uit fractie $I$ werden anwijzingen verkregen dat meerdere elwitten een bijdrage leverden an de Inductie van VTO met fractie I. Eén van deze elwiten (molecuulgewicht 20.400) werd gezulverd.

Aangezien de beschermende componenten van fractie I niet konden worden geidentificeerd, werden verdere experimenten beperkt tot opheldering van het mechantsme van de bescherming geinduceerd door RNA plus DDA. Bescherming tegen L. monocytogenea kon niet alleen gelnduceerd worden met Listerla-RNA plus DDA, mar ook met heteroloog ribosomal RNA (gelsoleerd ult . aerminasa) plug DDA of met symthetisch RNA (poly A:U) plus DDA. Op basls van deze warneming werd de hypothese geformleerd dat de bescherming geinduceerd met Listeria-RNA plus DDA warschijnlijk niet gebaseerd was op herkenning van Listeria-antigenen door Listerta-specifleke $\mathrm{T}$-cellen. Deze hypothese werd onderzocht met behulp wan cyclosporine $A$, warnee de Inductie van $T$-cel afhankelfjke immunitelt tegen Listeria kan worden onderdrukt. Behandeling van mulzen met cyclosporine A verhinderde de inductie van bescherming door immunfatile met levende Listerla, maar had geen effect op de Inductl van 
bescherming met RNA plus DDA, zodat het $T$-cel onafhankel1jke karakter van de verhoogde weerstand gelnduceerd met RNA plus DDA kon worden beveat 1 gd.

Na opwekking van een ontstekingareactle in de bulkholte door injectle van proteose pepton bleken alch in de bulkholte van mulzen behandeld met RNA plus DDA aanzlenl1jk meer polymorfonuclealre leukocyten (PMNs) en macrofagen op te hopen dan in de bulkholte van mulzen behandeld met DDA alleen. De bescherming: getnduceerd door RNA plus DDA was derhalve geassocleerd met een versterking van aspecifieke ontstekingsreacties. Een versterkte ontstekingsreactie (vooral van PMNs) werd ook wargenomen in mulzen behandeld met poly A:U plus DDA.

Onbehandelde mulzen konden tegen een dodelijke Ltsterla-infectie beschermo worden door injectle van ontstekings-PMNs of ontstekings-macrofagen geIsoleerd ult mulzen behandeld met RMA plus DDA, maar niet door injectie van PMNs of macrofagen gelsoleerd uit mulzen behandeld met DDA alleen. Zowel PMNis als macrofagen geYsoleerd ult mulzen behandeld met RNA plus DDA leken derhalve geactlveerd te $z 1 j n$ ten opzlchte van dezelfde cellen gelsoleerd ult mulzen behandeld met DDA alleen.

In tegenstelling tot de bescheming tegen $L$. monocytogenes geInduceerd door Immunisatie met levende Listeria was de bascherming gernduceerd met RNA plus DDA T-cel onafhankelijk en - althans gedeeltel1jk - gebaseerd op activering van PMNs, cellen waarvan In het alyemeen wordt aangenomen dat deze slechts van weinig belang zijn voor de eliminatle van intracellulaire parasieten zoals Llsteria monocytogenes. 


\section{DANKWOORD}

Tot slot zou th een woord van dank wllen richten tot allen dle op enlgerlei wijze een bijdrage hebben geleverd aan het totstandkomen van dit proefschrift. Mijn speciale dank gaat uit naar:

- mijn promotor Prof.Dr. C.P.A. van Boven voor zijn hulp en wardevolle adviezen.

- Dr. J.F. van den Bosch voor zijn begelelding en vele stimulerende discussies.

- Mw.Dr. R. Kolfschoten-Gonggrijp voor het overdragen van har kennis met betrekking tot de berelding van ribosonale vacins.

- Paul Lemmens, Iris Kanis en Wll Mullers voor hun ultstekende praktische ondersteuning en grote inzet bij het witvoeren van de experimenten.

- Dr. W.A. Buurman voor zijn bljdrage an de experimenten, beschreven in hoofdstuk 8 en zijn advlezen met betrekking tot hoofdstuk 6 en hoofdstuk 7 .

- de medewerkers en medewerksters van de centrale Proefdleren Voorzleningen voor het verzorgen van de proefdleren.

- Fia Claus-Hahn, Carla Hendrix-Vogels, Lillan kreusch en Jo Stallinga voor de uitstekende verzorging van het vele typewe rk.

- Fia Claus-Hahn tevens voor hat assigtentie bij de verzorging van de lay-out van het proefschrift.

Naast bovenvermelde personen hebben vele anderen, al dan niet behorend tot de capaciteltsgroep Medische Microbiologle, hun steentje bijgedragen aan dit proefschrlft door het verlenen van hand- en spandiensten of het verstrekken van adwlezen. Ook naar hen gaat mijn dank ult. 
Last, but not least, zou ik Dr. W. Engels willen bedanken voor $z$ ijn hulp bij het drukklaar maken van het manuscript. 
Ad Antonlssen werd op 22 april 1953 geboren te Oudenbosch. Na het behalen van het diploma Gymasium in Junt 1971 studeerde hij scheikunde aan de Rijksuniversitelt te Utrecht. Het kand daatsexamen SI werd afgelegd in Junt 1975 en het doctoraal-examen (hoofdwak blochemie, bijvak Lmmonologie) in oktober 1979. Van 15 oktober 1979 tot 1 januar1 1981 was hij wetenschappelljk assistent bij de sectie experimentele tmunologie van het laboratorlum woor microbiologie (vakgroep besmettingsleer van de medische facultelt) te Utrecht alwar onder leiding van Dr. H. van Dijk en Prof. Dr. J.M.N. WHllers onderzoek werd verricht aan een kNasewgevoellg vaccin gelsoleerd uit Listerla monocytogenes.

Van 1 mel 1981 tot 1 mei 1985 was hij wetenschappelijk ambtenaar bij de capaciteitsgroep medische microbiologie van de Rljksuniversitelt Limburg, alwar het in dit proefschrift beschreven onderzoek werd uitgevoerd. 